US Army Corps

of Engineers

Waterways Experiment

Station

\title{
Effectiveness of Beach Nourishment on Cohesive Shores, St. Joseph, Lake Michigan
}

by Robert B. Nairn, Peter Zuzek, Baird \& Associates Andrew Morang, Larry E. Parson, WES

Approved For Public Release; Distribution Is Unlimited

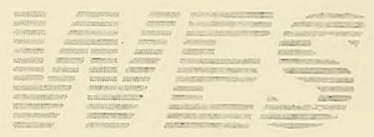


The contents of this report are not to be used for advertising, publication, or promotional purposes. Citation of trade names does not constitute an official endorsement or approval of the use of such commercial products.

The findings of this report are not to be construed as an official Department of the Army position, unless so designated by other authorized documents. 


\section{Effectiveness of Beach Nourishment on Cohesive Shores, St. Joseph, Lake Michigan}

by Robert B. Naim, Peter Zuzek

W.F. Baird \& Associates, Coastal Engineers, Ltd.

221 Lakeshore Road East, Suite 301

Oakville, Ontario, Canada L6J $1 \mathrm{H} 7$

Andrew Morang, Larry E. Parson

U.S. Army Corps of Engineers

Waterways Experiment Station

3909 Halls Ferry Road

Vicksburg, MS 39180-6199

Final report

Approved for public release; distribution is unlimited 


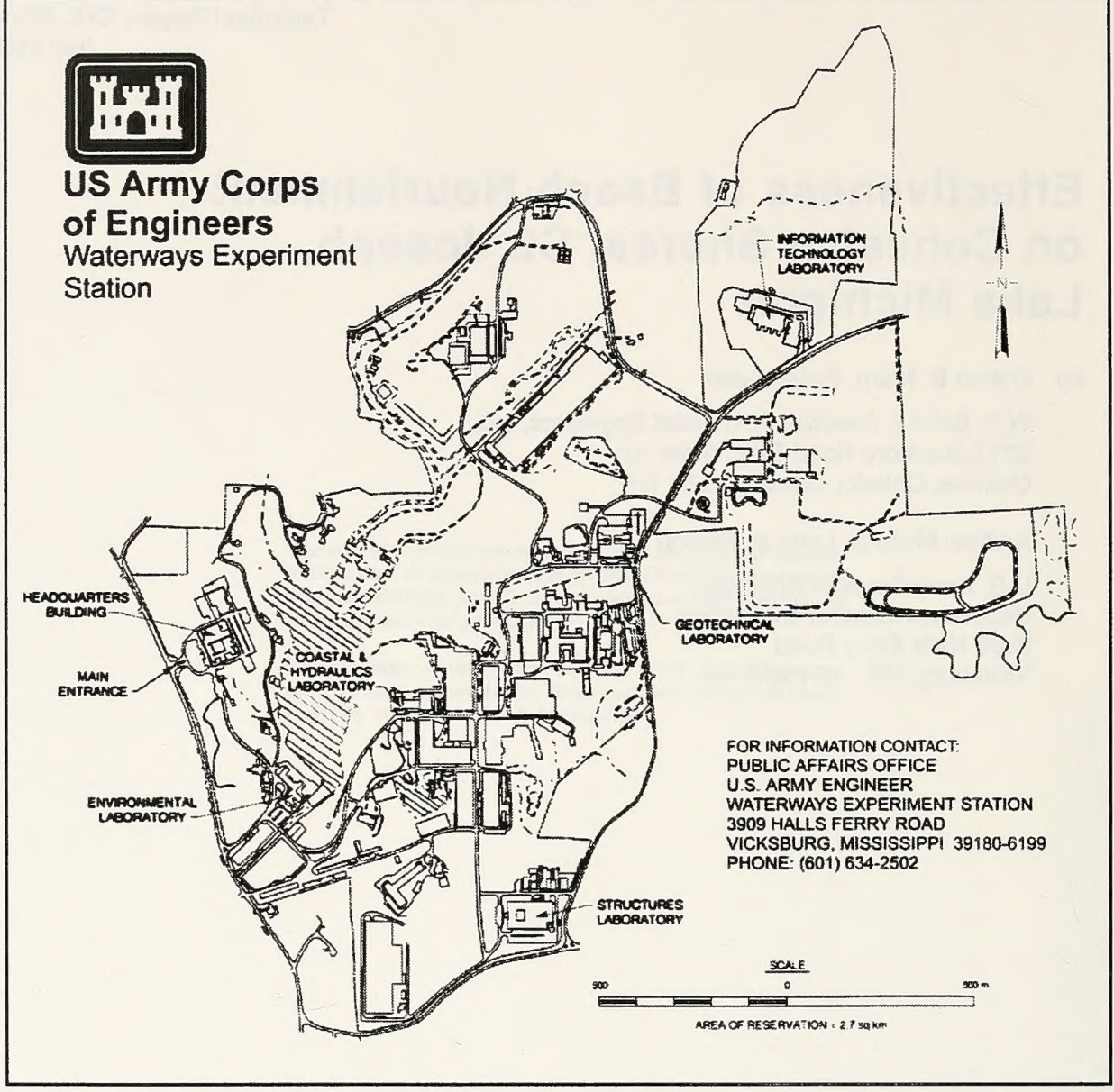

\section{Waterways Experiment Station Cataloging-in-Publication Data}

Effectiveness of beach nourishment on cohesive shores, St. Joseph, Lake Michigan / by

Robert B. Nairn ... [et al.] ; prepared for U.S. Army Corps of Engineers.

102 p. : ill. ; $28 \mathrm{~cm}$. - (Technical report ; CHL-97-15)

Includes bibliographic references.

1. Beach nourishment - Michigan - Saint Joseph. 2. Sediment transport. 3. Saint Joseph (Mich.) 4. Harbors - Michigan. I. Nairn, Robert Bruce, 1960- II. United States. Army. Corps of Engineers. III. U.S. Army Engineer Waterways Experiment Station. IV. Coastal and Hydraulics Laboratory (U.S. Army Engineer Waterways Experiment Station) V. Series: Technical report (U.S. Army Engineer Waterways Experiment Station) ; CHL-97-15.

TA7 W34 no.CHL-97-15 


\section{Contents}

Preface

1 -Introduction $\ldots \ldots \ldots \ldots \ldots \ldots \ldots \ldots \ldots \ldots \ldots \ldots \ldots \ldots \ldots \ldots \ldots$

2-Background $\ldots \ldots \ldots \ldots \ldots \ldots \ldots \ldots \ldots \ldots \ldots \ldots \ldots \ldots \ldots \ldots \ldots \ldots$

Regional Coastal Processes and Geomorphology . . . . . . . . . . 3

Site Conditions and Beach Nourishment History . . . . . . . . . 3

Discussion of Cohesive Shores . . . . . . . . . . . . 8

3 -Existing Data Sources $\ldots \ldots \ldots \ldots \ldots \ldots \ldots \ldots \ldots$

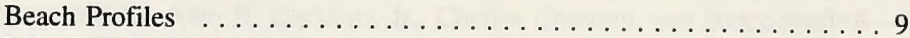

Lake Bed Bathymetry . . . . . . . . . . . . . . . . 9

Wave and Water Level Data . . . . . . . . . . . . . . . . 9

Shoreline Recession . . . . . . . . . . . . . . . . . 14

4 -Analyses of Coastal Processes and Geomorphology . . . . . . . . 16

Results of the Alongshore Sediment Transport Calculations . . . . . 16

Single grain size across the profile $\ldots \ldots \ldots \ldots \ldots \ldots \ldots \ldots$

Multiple grain sizes across a profile $\ldots \ldots \ldots \ldots \ldots \ldots \ldots \ldots$

Annual variation in potential alongshore sediment transport . . . . . 22

Historic variability in potential alongshore sediment transport related to profile change .............. 25

Bypassing and channel infilling at St. Joseph Harbor . . . . . . . 27

Results of Cross-Shore Modeling with Multiple Grain Sizes . . . . . . . 31

COSMOS-3D Modeling . . . . . . . . . . . . . . . . 37

Methodology . . . . . . . . . . . . . . . . . 37

General results $\ldots \ldots \ldots \ldots \ldots \ldots \ldots \ldots \ldots \ldots \ldots \ldots$

Runs $\mathrm{A}$ to $\mathrm{C}$ (initial series) $\ldots \ldots \ldots \ldots \ldots \ldots \ldots \ldots \ldots \ldots \ldots$

Runs $\mathrm{D}$ to $\mathrm{F}$ (post beachfill series) . . . . . . . . . . . 48

Runs $\mathrm{G}$ and $\mathrm{H}(2 \mathrm{~mm}$, coarse sediment $) \ldots \ldots . \ldots . \ldots . . . . .49$

Runs I and J (high water level) . . . . . . . . . . . . 49

Runs K and L (pre- and post-fill with $0.5-\mathrm{m}$ marker depth) . . . . . 49

Assessment of predicted glacial till downcutting . . . . . . . . 50

Summary of the $3-\mathrm{D}$ results $\ldots \ldots \ldots \ldots \ldots \ldots \ldots$

Trends in Profile Change . . . . . . . . . . . . . . . . . 57

Long-term profile change $\ldots \ldots \ldots \ldots \ldots \ldots \ldots \ldots$

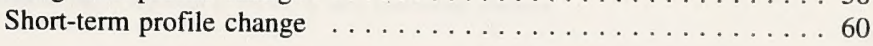


Exposure of the Cohesive Substrate . . . . . . . . . . . . . 64

Bathymetry Comparisons and Sediment Budget Calculations . . . . 68

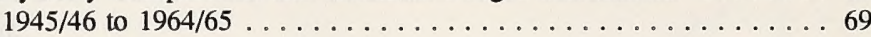

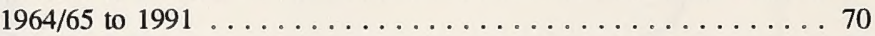

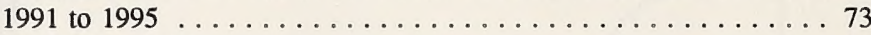

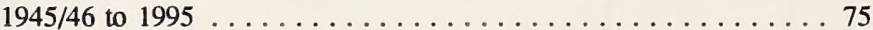

5-Interpretation of Results - A Descriptive Model of Coastal

Morphodynamics . . . . . . . . . . . . . . . . . 77

Historic Conditions . . . . . . . . . . . . . . . . . 79

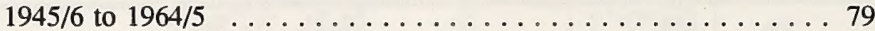

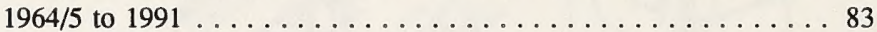

Existing and Future Conditions . . . . . . . . . . . 84

Existing conditions (1991 to 1995$) \ldots \ldots \ldots \ldots \ldots \ldots \ldots$

Projections of future conditions $\ldots \ldots \ldots \ldots \ldots \ldots \ldots$

Comments on the Effectiveness of the Beach Nourishment Program . . 87

Recommendations for Future Monitoring . . . . . . . . . 88

6-Beach Nourishment Design Guidelines . . . . . . . . . . . . . . . 89

Recommendations for St. Joseph . . . . . . . . . . . . . . . . . 89

General Recommendation for Beach Nourishment on Cohesive

Shores Downdrift of Harbor Structures . . . . . . . . . . . . . 990

7 -References ............................ 93

SF 298 


\section{Preface}

The investigation summarized in this report was conducted by the U.S. Army Engineer Waterways Experiment Station's (WES's) Coastal and Hydraulics Laboratory (CHL). The CHL was formed in October 1996 with the merger of the WES Coastal Engineering Research Center and Hydraulics Laboratory. Dr. James R. Houston is the Director of the CHL and Messrs. Richard A. Sager and Charles C. Calhoun, Jr., are Assistant Directors. This project was selected for study and funded by the Monitoring Completed Navigation Projects (MCNP) program. The MCNP Program Manager is Ms. Carolyn Holmes, CHL. This program is sponsored by Headquarters, U.S. Army Corps of Engineers (HQUSACE). The HQUSACE Technical Monitors are Messrs. John H. Lockhart, Jr., Charles Chesnutt, and Barry W. Holliday. The project is under the jurisdiction of the U.S. Amy Engineer District, Detroit.

Work was performed under the general supervision of Ms. Joan Pope, Chief, Coastal Structures and Evaluation Branch (CSEB), CHL; and Mr. Thomas W. Richardson, Chief, Engineering Development Division, CHL.

This report was prepared by Dr. Robert Naim and Mr. Peter Zuzek of W. F. Baird and Associates, Coastal Engineers, Ltd., and by Mr. Larry E. Parson and Dr. Andrew Morang, CHL. Field data were collected by the Detroit District's Grand Haven Area Office, CHL, the U.S. Geological Survey, Westem Michigan University, and the University of Michigan. Technical reviewer of the report was Mr. Edward B. Hands, CHL.

At the time of publication of this report, Director of WES was Dr. Robert W. Whalin. Commander was COL Bruce K. Howard, EN.

The contents of this report are not to be used for advertising, publication, or promotional purposes. Citation of trade names does not constitute an official endorsement or approval of the use of such commercial products. 



\section{Introduction}

This report describes a study into the effectiveness of beach nourishment along the cohesive shore south of St. Joseph Harbor on Lake Michigan. The study was funded by the U.S. Army Engineer Waterways Experiment Station under the Monitoring Completed Navigation Projects (MCNP) Program.

The objectives of this study were as follows:

a. To improve understanding of the sediment transport processes for both fine-grain and coarse-grain sand components at this site.

$b$. To improve understanding of the relationship between the movement of the cohesionless sediment (both fine- and coarse-grain components) and the irreversible downcutting of the underlying glacial till (cohesive sediment) at this site.

c. To apply the improved understanding of the sediment transport and erosion processes in developing recommendations for beach nourishment at the St. Joseph site.

d. To formulate general principles for beach nourishment of cohesive shore sites which suffer from a sediment supply deficit due to the presence of an updrift littoral barrier.

The study was based on a comprehensive database of the site conditions which were collected under the MCNP Program of the U.S. Army Corps of Engineers, Coastal Engineering Research Center. A companion report by Parson, Morang, and Nairn (1996) discusses geologic control on shoreline stability for southeast Lake Michigan. Another report by Parson and Smith (1995) describes an investigation of native beach characteristics for this section of the Lake Michigan shoreline. These supporting documents include important background information on the analyses and interpretations presented in this report, including:

a. A description of the geologic setting.

$b$. A summary of the results of the monitoring program activities. 
c. Laboratory experiments performed in a unidirectional flow flume to assess the erosion rates of undisturbed till samples which were extracted from the lake bed offshore of St. Joseph.

Chapter 2 of this report provides a review of the information presented in the companion reports as well as an overview of the problem at St. Joseph. In addition, cohesive shore processes are summarized.

A summary of the data used for the analyses completed as part of this investigation is presented in Chapter 3 . The primary components of these data consist of repeated beach profiles, lake bed bathymetry, and shoreline recession rates. The results of additional data collection, including subsurface profiling with ground-penetrating radar and sediment sampling, are presented in the companion reports by Parson, Morang, and Nairn (1996) and by Parson and Smith (1995), respectively.

Chapter 4 presents the results of a series of analyses performed to develop an understanding of the evolution of the shoreline and lake bed in the vicinity of St. Joseph and the influence of the beach nourishment program on the evolution. These analyses include 2-dimensional (2-D) and 3-dimensional (3-D) numerical modeling of sediment transport, profile comparisons, and bathymetry comparisons.

Based on the results of the analyses described in this report, and from the companion report by Parson, Morang, and Nairn (1996), a descriptive model of the historic coastal morphodynamics in the vicinity of St. Joseph is developed and presented in Chapter 5. This descriptive model is used to project the future evolution of coastal morphology. It is in this context that the effectiveness of the ongoing beach nourishment program is evaluated.

Recommendations for future nourishment efforts at St. Joseph are made on the basis of establishing realistic goals for the program in Chapter 6 of the report. A discussion of general principles for beach nourishment design on cohesive shores downdrift of harbor structures concludes the report. 


\section{Background}

\section{Regional Coastal Processes and Geomorphology}

In general terms, this section of the southeastem Lake Michigan shore is characterized by eroding bluffs which consist of glacial deposits with some instances of relict dune formations. A detailed summary of the morphology and related references for this section of the Lake Michigan coast is provided by Parson and Smith (1995). The general coastal morphology of Lake Michigan is described by Hands (1970).

The lake bed also consists of glacial sediments (with isolated outcroppings of shale bedrock) covered with a veneer of sand and gravel of variable thickness. The sand and gravel cover represents a recent (i.e., in a geological time perspective) lag deposit that has been derived from the erosion of the lake bed and bluff in this region. Near the mouth of the St. Joseph River, the presence of an incised valley results in a very thick cover of sand over the underlying glacial sediment. However, along most of the coast, the glacial sediment is probably within 0 to $4 \mathrm{~m}$ of the lake bed surface. A discussion of the processes of shoreline recession on such "cohesive shores" is presented later in this chapter.

The 120-year bluff recession rate, averaged for Berrien County, was about $0.6 \mathrm{~m} /$ year (Hands 1976). Short-term and local rates can be much higher, particularly during periods of high lake levels. Downcutting of the lake bed between 3 and $4 \mathrm{~m}$ has been reported by Foster et al. (1992) for the period between 1945 and 1991 south of St. Joseph Harbor. The net alongshore sediment transport direction is from north to south. The harbor jetties act as partial to full littoral transport barriers.

\section{Site Conditions and Beach Nourishment History}

This investigation will focus on a $12-\mathrm{km}$ section of shoreline extending $3 \mathrm{~km}$ north of, and $9 \mathrm{~km}$ south of, the harbor jetties at St. Joseph (refer to Figure 1). Immediately north of the harbor entrance, the fillet beach influences the shoreline morphology for approximately $1 \mathrm{~km}$. The remaining $2 \mathrm{~km}$ of 


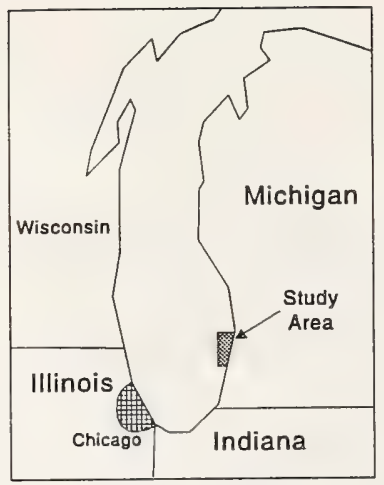

LAKE

WICHIGAN

$+1$

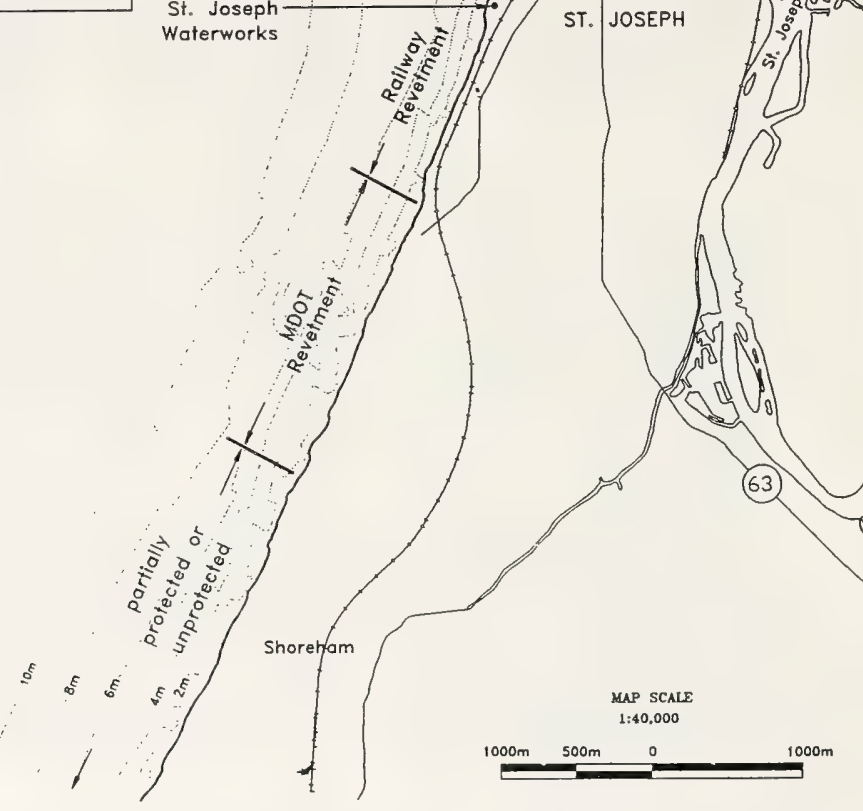

Figure 1. Site conditions

shoreline north of the harbor jetties are not influenced by the harbor structures. There is a small downdrift fillet beach immediately south of the harbor, about $400 \mathrm{~m}$ in length. The 1.1-km section of shore between the fillet beach and the 
Waterworks revetment to the south is partially protected by deteriorated groins. The feeder beach for the nourishment program extends from Park St. (located about $600 \mathrm{~m}$ south of the south jetty) to just south of the Waterworks revetment. Beginning with the Waterworks revetment and extending about $3.5 \mathrm{~km}$ to the south, the shore is protected by an armor stone revetment (constructed for the Chesapeake and Ohio Railroad over the first $1.5 \mathrm{~km}$ and for the highway by the Michigan Department of Transportation, (MDOT), for the next $2 \mathrm{~km}$ ). In some places, the revetment is fronted by groins, many of which are in disrepair. The final $3.3 \mathrm{~km}$ of shore south of the end of the revetment consists of various forms of deteriorated wall structures and entirely unprotected sections.

A Section 111 mitigation plan was implemented downdrift of St. Joseph Harbor in 1976 by the U.S. Army Corps of Engineers (USACE) to address the erosion problems that may be associated with the interception of sediment on the updrift side of the structures. The harbor jetties were constructed originally in 1903 and have been estimated to trap approximately $84,000 \mathrm{~m}^{3}$ of sediment per year (USACE 1973). The mitigation consisted of placing fine sand from the harbor maintenance dredging on the downdrift beaches (Johnson 1992). More than $1,700,000 \mathrm{~m}^{3}$ of sand has been placed on the beaches of St. Joseph. Table 1 provides the annual placement details for beach nourishment between 1970 and 1995. Parson (1992) has indicated that the fine sand has been a less-than-ideal material for nourishment, noting its short retention time and the fact that the fine sand does not fulfill the role of the coarser sediment which forms a large part of the natural beach closer to shore (i.e., in the surf and swash zones).

Coarse material was placed on the beach in 1986, 1987, 1988, 1991, 1993 and, most recently, in the fall of 1995 (see Table 1). This coarse sediment came from upland sources and was trucked to the site. The coarse grain sediment has a $d_{50}$ of about $2 \mathrm{~mm}$ and is well-sorted with a range of grain sizes from $0.1 \mathrm{~mm}$ to $32 \mathrm{~mm}$. This material has a longer retention time and it has been postulated that it may protect the underlying glacial till from erosion in the critical nearshore zone (Parson 1992).

The beach nourishment is placed between the ordinary high water mark (OHWM) (177.2 m International Great Lakes Datum (IGLD), 1985) and the most landward 1.2-m depth contour $(174.8 \mathrm{~m})$. The maximum design height for the placed material is $178.3 \mathrm{~m}$ and its maximum width is $46 \mathrm{~m}$. The typical beach nourishment volume is about $50 \mathrm{~m}^{3} / \mathrm{m}$ over the $1-\mathrm{km}$-long feeder beach or about $50,000 \mathrm{~m}^{3}$ in total with fine sediment applied in the spring and coarse sediment in the fall.

To classify nourishment volumes and include the results in the descriptive model, annual beach nourishments were grouped into three time periods: 1970 to 1975,1976 to 1991 , and 1991 to 1995 , for both fine (dredged) and coarse (trucked) sand (see Figure 2). Prior to the implementation of the Section 111 plan in 1976, annual nourishment volumes averaged $23,000 \mathrm{~m}^{3}$ and there was no trucking from inland borrow sites. From 1976 to 1991, average annual 


\begin{tabular}{|c|c|c|c|c|c|c|}
\hline \multicolumn{7}{|c|}{$\begin{array}{l}\text { Table } 1 \\
\text { Nourishment Details for St. Joseph Harbor, Michigan } \\
\text { (from U.S. Army Engineer District, Detroit) }\end{array}$} \\
\hline Year & Date & $\begin{array}{l}\text { Dredged } \\
\left(\mathrm{m}^{3}\right)\end{array}$ & $\begin{array}{l}\text { Trucked } \\
\left(\mathrm{m}^{3}\right)\end{array}$ & Type & $\begin{array}{l}\begin{array}{l}\text { Total Year } \\
\left(\mathrm{m}^{3}\right)\end{array} \\
\end{array}$ & Location of Beach Fill Placement \\
\hline 1970 & & 22,901 & & fin & 22,901 & \\
\hline 1971 & & 16,260 & & fine & 16,260 & \\
\hline 1972 & & 32,824 & & fine & 32,824 & \\
\hline 1973 & & 6,107 & & fine & 6,107 & \\
\hline 1974 & & 19,542 & & fine & 19,542 & \\
\hline 1975 & & 38,779 & & fine & 38,779 & \\
\hline $1976^{1}$ & & 71,908 & 212,213 & fine & 284,121 & \\
\hline 1977 & & 123,664 & & fine & 123,664 & \\
\hline 1978 & & 68,321 & & fine & 68,321 & \\
\hline 1979 & & 84,580 & & fine & 84,580 & \\
\hline 1980 & & 70,992 & & fine & 70,992 & \\
\hline 1981 & & 50,229 & & fine & 50,229 & \\
\hline 1982 & & 89,771 & & fine & 89,771 & \\
\hline 1983 & & 169,084 & & fine & 169,084 & \\
\hline 1984 & & 76,336 & & fine & 76,336 & \\
\hline 1985 & & 28,779 & & fine & 28,779 & \\
\hline 1986 & & 11,221 & 120,229 & fine/coarse & 131,450 & \\
\hline 1987 & 14 Sept. to 20 Nov. & & 51,527 & coarse & 51,527 & $2250 \mathrm{ft}-4650 \mathrm{ft}$ South \\
\hline 1988 & 31 May to 29 July & 33,728 & & fine & 33,378 & $\begin{array}{l}\text { Park St. - } 3400 \mathrm{ft} \text { South } \\
\text { (OHWM - 8-ft Contour) }\end{array}$ \\
\hline 1988 & 19 Oct. to 19 Nov. & & 51,527 & coarse & 51,527 & $\begin{array}{l}\text { CL of Park St. - } 2700 \mathrm{ft} \text { South } \\
\text { (OHWM - } 4 \text {-ft Contour) }\end{array}$ \\
\hline 1989 & 24 May to 22 June & 14,309 & & fine & 14,309 & $\begin{array}{l}\text { CL Park St. Ext } 2700 \mathrm{ft} \\
\text { (OHWM - 8-ft Contour) }\end{array}$ \\
\hline 1990 & 22 May to 22 June & 44,515 & & fine & 44,515 & $\begin{array}{l}\text { CL Park St. Ext } 2700 \mathrm{ft} \text { South } \\
\text { (OHWM - 7-ft Contour) }\end{array}$ \\
\hline 1991 & 3 May to 22 May & 40,086 & & fine & 40,086 & $\begin{array}{l}\text { CL Park St. Ext } 2700 \mathrm{ft} \text { South } \\
\text { (OHWM 7-ft Contour) }\end{array}$ \\
\hline 1991 & 3 Sept. to 30 Sept. & & 63,651 & coarse & 63,651 & $\begin{array}{l}\text { CL Park St. Ext } 2800 \mathrm{ft} \text { South } \\
\text { (OHWM - 4-ft Contour) }\end{array}$ \\
\hline 1992 & 22 May to 9 June & 25,682 & & fine & 25,682 & $\begin{array}{l}\text { CL Park St. Ext } 2700 \mathrm{ft} \text { South } \\
\text { (OHWM - 7-ft Contour) }\end{array}$ \\
\hline 1993 & 18 June to 30 July & 1,756 & & fine & 1,756 & $\begin{array}{l}50 \mathrm{ft} \text { South of CL Park St. Ext } \\
2700 \mathrm{ft} \mathrm{S}(\mathrm{OHWM}-7 \text { - } \mathrm{ft} \text { Contour) }\end{array}$ \\
\hline 1993 & 7 Sept. to 29 Oct. & & 45,821 & coarse & 45,821 & $\begin{array}{l}1200 \mathrm{ft} \text { South of CL Park St. Ext } \\
1300 \mathrm{ft} \mathrm{S}(\mathrm{OHWM}-4-\mathrm{ft} \text { Contour) }\end{array}$ \\
\hline 1994 & June & 24,000 & & fine & 24,000 & Shoreham \\
\hline 1995 & Sept. - Nov. & & 43,350 & coarse & 43,350 & Lions Park \\
\hline \multicolumn{2}{|c|}{$\begin{array}{l}\text { Total }\left(\mathrm{m}^{3}\right) \\
\text { Average/year }\left(\mathrm{m}^{3}\right)\end{array}$} & $\begin{array}{r}1,165,374 \\
44,822\end{array}$ & $\begin{aligned} 588,318 \\
22,628\end{aligned}$ & & & \\
\hline
\end{tabular}




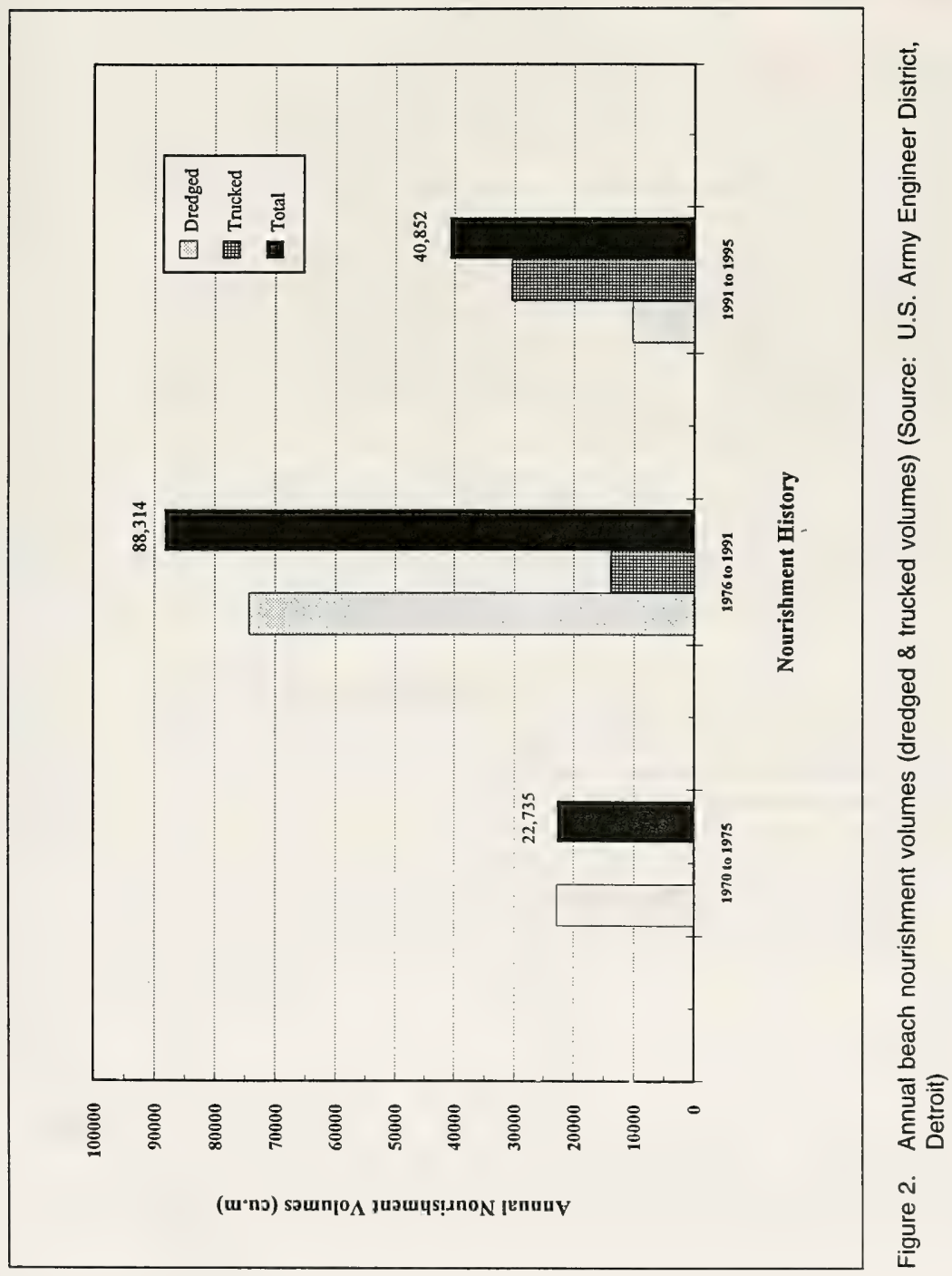


nourishment volumes from dredging increased to $74,000 \mathrm{~m}^{3} /$ year, with an additional $14,000 \mathrm{~m}^{3} /$ year of coarse sand trucked from inland borrow sites, for a total of $88,000 \mathrm{~m}^{3} /$ year. From 1991 to 1995 , combined dredged and trucked volumes average only $41,000 \mathrm{~m}^{3} /$ year, a substantial reduction from the annual volume delivered to the feeder beach between 1976 and 1991.

\section{Discussion of Cohesive Shores}

Sandy shores are generally distinguished by an inexhaustible local supply of beach sediment. In contrast, a shore is defined as cohesive when a cohesive sediment substratum (such as glacial till, glaciolacustrine deposits, soft rock or other consolidated deposits) occupies the dominant role in the change of the shoreline shape (i.e., through erosion). In other words, underneath any cohesionless deposit (i.e., sand and gravel) there is an erodible surface which plays the most important role in determining how these shorelines erode, and ultimately, how they evolve. A cohesive shore erodes and recedes because of the permanent removal and loss of the cohesive sediment (both from the bluff and the lake bed). The sand cover may come and go (depending on the season, water level, and storm activity), but the erosion of the cohesive layer is irreversible. The characteristics of cohesive shores are discussed in more detail in Parson, Morang, and Nairn (1996).

The critical point to understand is that shoreline recession, and the associated problems of undermining of shore-based structures, could not continue without the ongoing downcutting of the nearshore lake bed. The long-term average rate at which the bluff or shoreline recedes on a cohesive shore must be governed by the rate at which the nearshore profile is eroded or downcut.

Where there are downdrift erosion problems related to the interception of sand at an updrift barrier on a cohesive shore, downdrift mitigation efforts such as beach nourishment must be carefully assessed, since the sand can act as either protective cover or as an abrasive agent (contributing to erosion) depending on the quantity and type of sediment. 


\section{Existing Data Sources}

\section{Beach Profiles}

A comprehensive profile monitoring plan was initiated with the beachfill of 1991 under the MCNP Program. Monitoring consisted of beach profile and lake bed surveys taken several times each year at seven transects spaced at about $200 \mathrm{~m}$ in the immediate fill area, and additional profiles at $800-\mathrm{m}$ intervals further to the south (a summary is provided in Table 2). The profile surveys are described by Parson, Morang, and Naim (1996) and an associated sediment sampling program is presented by Parson and Smith (1995). Section 111 profiles are designated with the letter " $R$ " and extend from north to south. Line R8 is the first profile south of the jetties, and R23 is the southern-most line monitored for this study (Figure 3). Four historical profile lines, Nos. 1, 2, 3, and 4, were also analyzed to determine multi-decade changes in offshore morphology.

\section{Lake Bed Bathymetry}

In 1995, the bathymetry of the study area was surveyed with new airbome technology. SHOALS (Scanning Hydrographic Operational Airbome LIDAR Survey) is a helicopter-mounted hydrographic surveying system which utilizes Light Detection and Ranging (LIDAR) to transmit and receive water surface and sea bottom signals. Using conventional acoustic methods, the bathymetry was previously surveyed in 1945/6, 1964/5, and in 1991 by the National Oceanic and Atmospheric Administration and the U.S. Geological Survey in a joint mapping project (Foster et al. 1992).

\section{Wave and Water Level Data}

Wave climate information has been generated by Hubertz, Driver, and Reinhard (1991) as part of the Coastal Engineering Research Center (CERC) Wave Information Studies (WIS). A detailed discussion of the wave hindcasts generated for this project is given in Parson, Morang, and Naim (1996). 


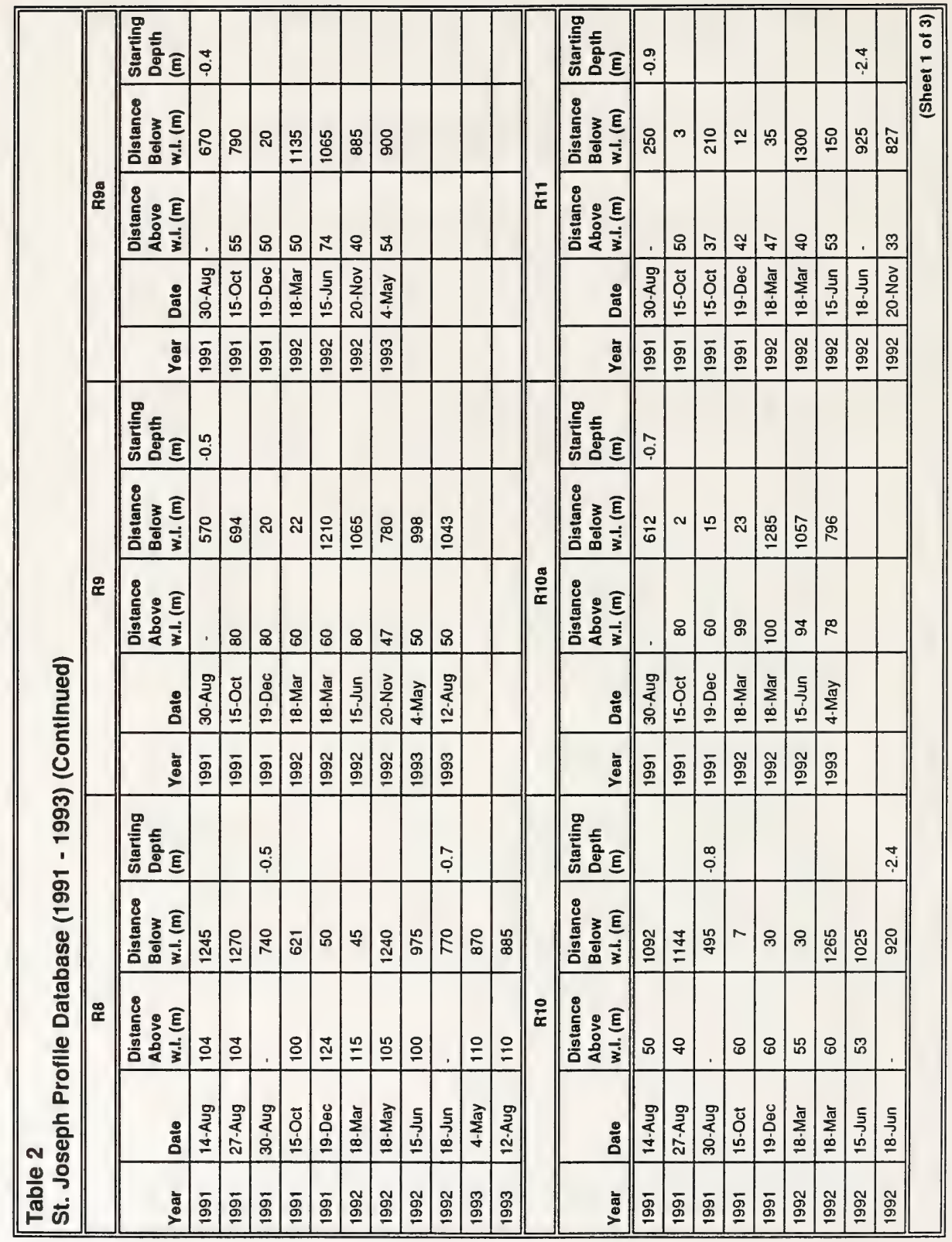




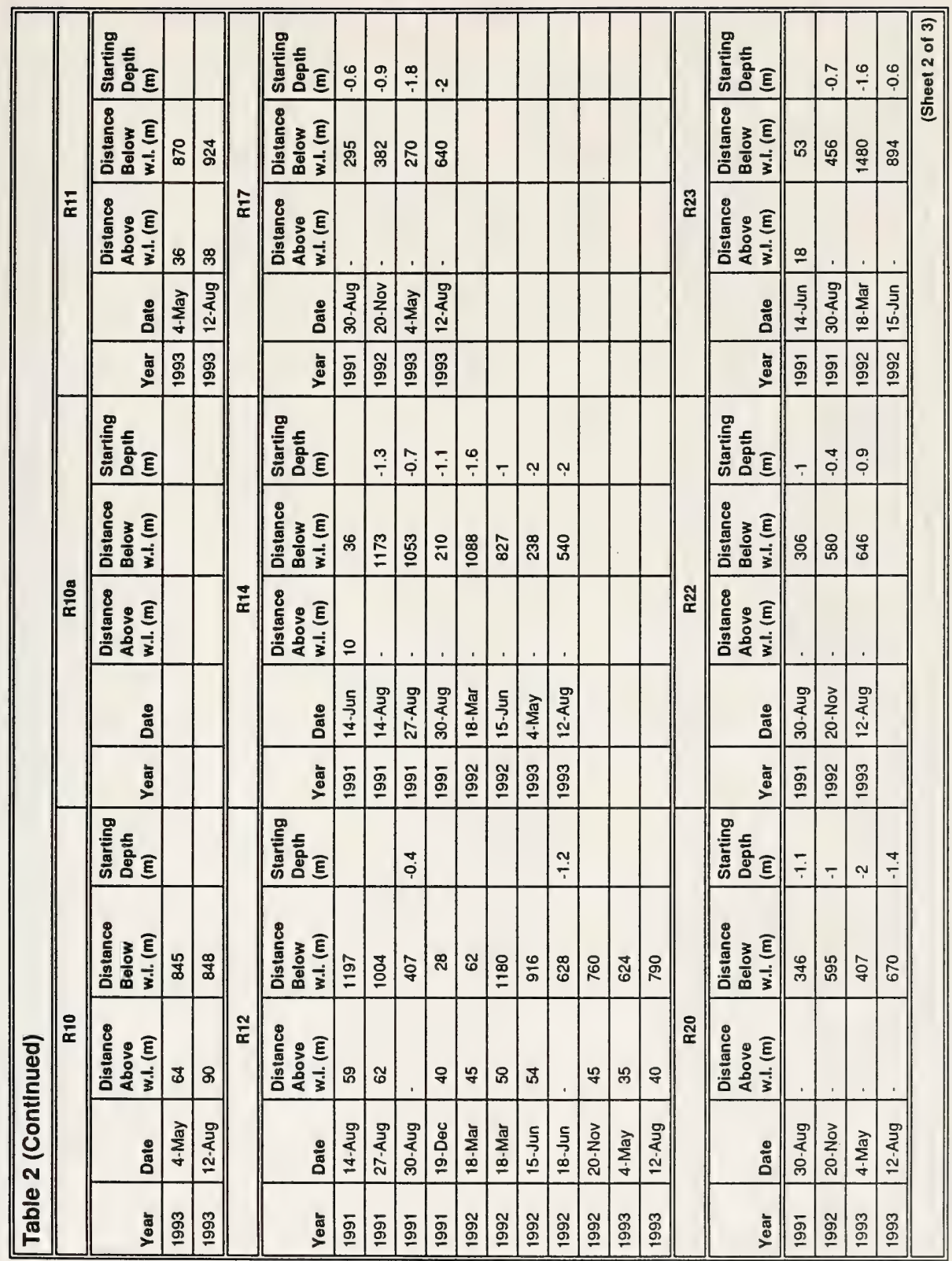




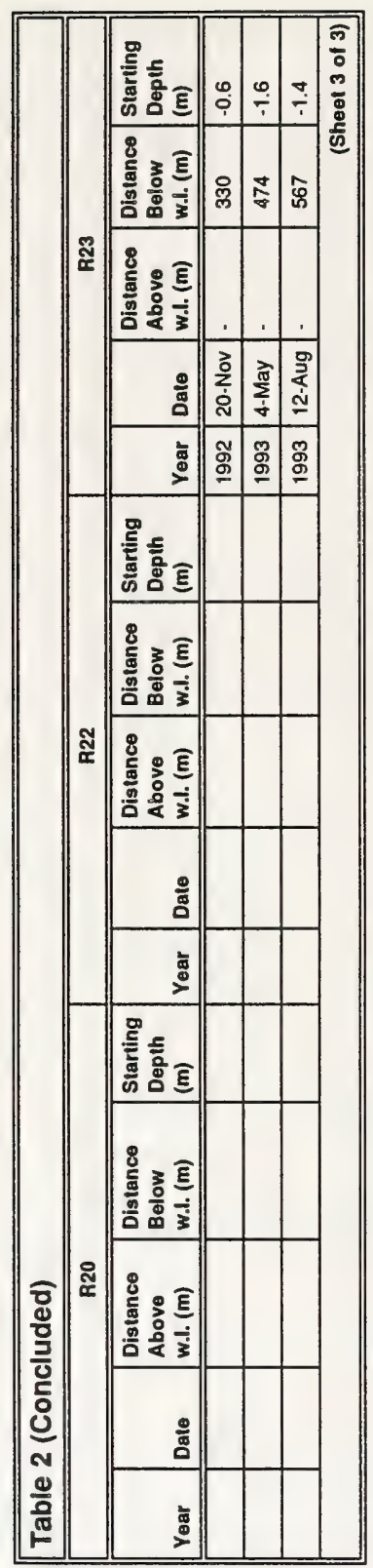




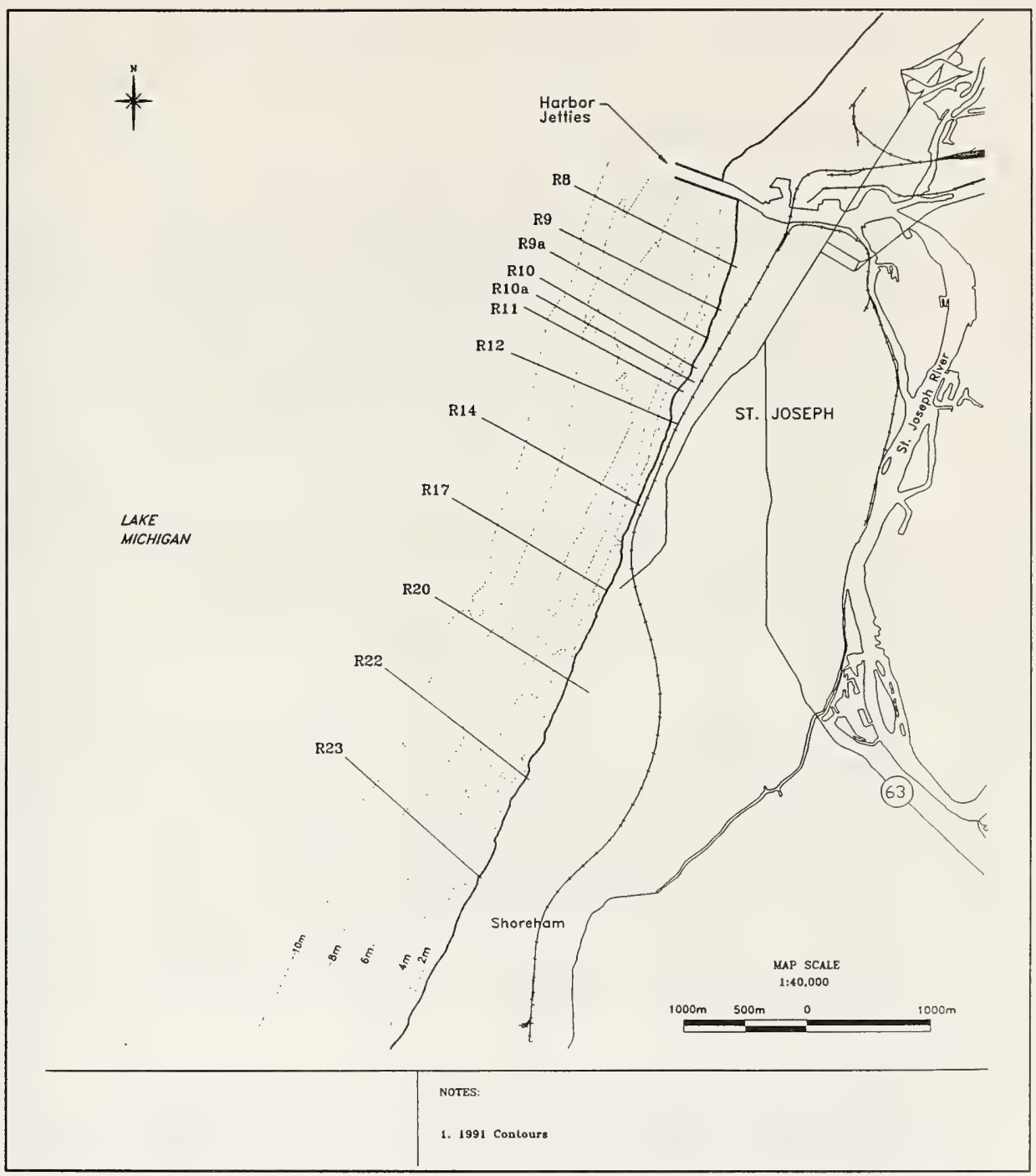

Figure 3. Profile locations 
Lake Michigan water levels are also discussed by Parson, Morang, and Naim (1996).

\section{Shoreline Recession}

An investigation of long-term shoreline recession rates north and south of the harbor jetties at St. Joseph was completed by the Land and Water Management Division, Michigan Department of Natural Resources (MDNR). The original study was completed in August 1978 to document change in shoreline location over a 40-year period. With the addition of a series of April 1989 aerial photographs, the original study was updated to describe 51 years of shoreline change. The length of the comparison masks the influence of such factors as fluctuating water levels, storms, shore protection structures, and other natural and human disturbances. Recession data for St. Joseph are summarized in Figure 4.

From the harbor jetties northward, the shoreline was accretional for $2.5 \mathrm{~km}$, with an average annual accretion rate of $0.96 \mathrm{~m} /$ year (see Figure 4). North of the accretional zone, the remaining $13 \mathrm{~km}$ of shoreline assessed by the MDNR had an average annual recession rate of $0.76 \mathrm{~m} / \mathrm{year}$. South of the harbor jetties, only the first $0.8 \mathrm{~km}$ of the shoreline (corresponding to the zone of influence from the fillet beach) had a long-term depositional trend, while the remaining $13 \mathrm{~km}$ of shore has been eroding at varying rates.

From the feeder beach at St. Joseph to the southem limits of the MDOT Revetment, the shoreline recession rates range from $0.36 \mathrm{~m} /$ year to $1.16 \mathrm{~m} /$ year. There are two possible explanations for erosion along the protected shore south of the harbor jetties: (a) the revetment was not present for the entire period of the air photo comparison, and/or (b) the revetment was constructed at the base of the bluff and the beach in front of the revetment has since eroded. When the results from the original investigation (August 1978) are compared to the second assessment (April 1989), in general, the annual rates of recession have decreased for the Railway and MDOT Revetment sections. This suggests that the shoreline recession rate has been reduced or eliminated locally with the construction of the revetment.

At Shoreham, where the shoreline is only partially protected, long-term recession rates are higher than to the north, ranging from 0.88 to $1.83 \mathrm{~m} /$ year. For the remaining $7 \mathrm{~km}$ of shoreline south of Shoreham, the average annual recession rate was $0.69 \mathrm{~m} /$ year. 


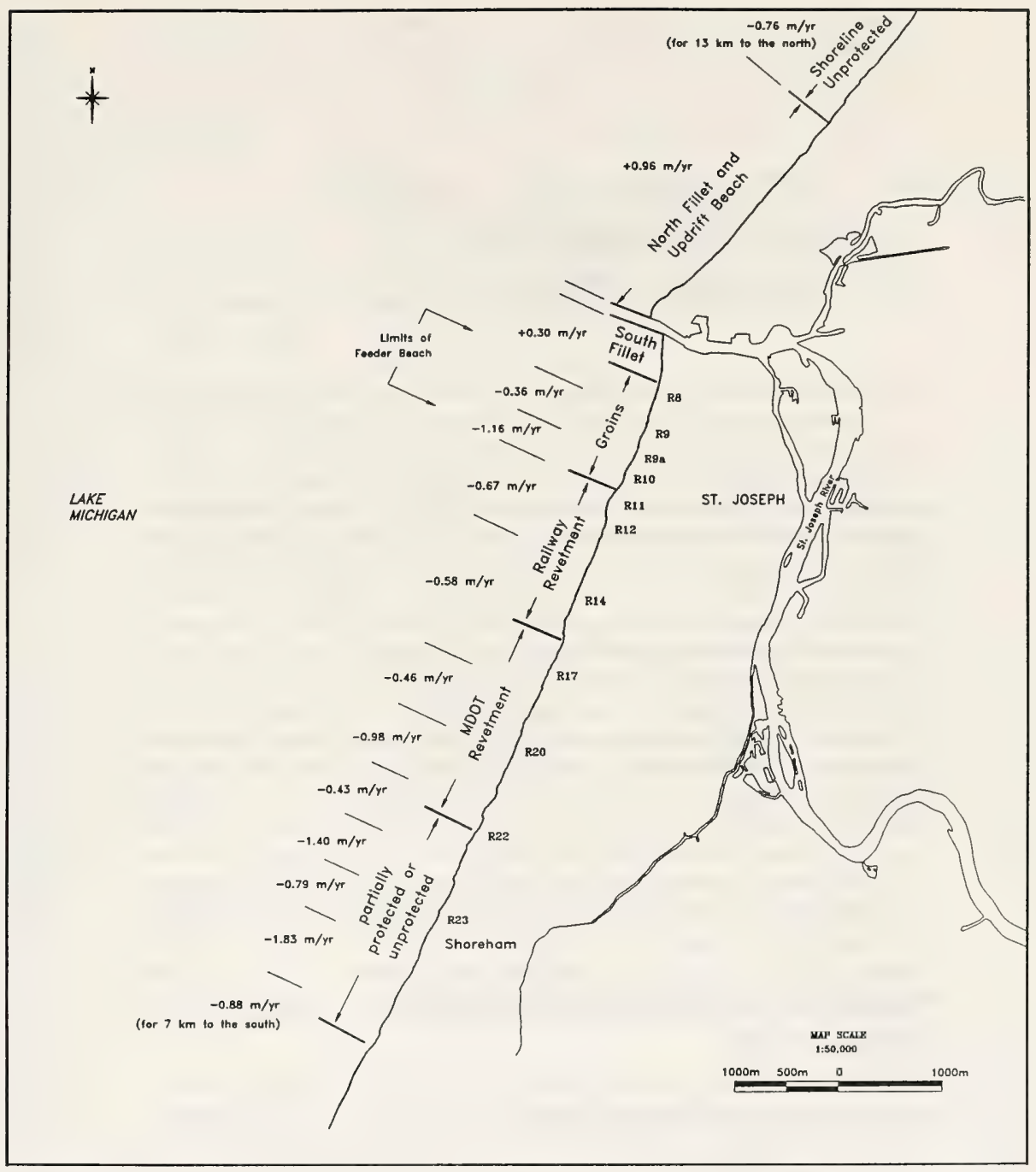

Figure 4. Historic annual recession rates (from Michigan DNR) 


\section{Analyses of Coastal Processes and Geomorphology}

This first part of this chapter consists of three sections describing: the alongshore sediment transport calculations; updated cross-shore sediment transport calculations (i.e., subsequent to those presented in Parson, Morang, and Nairn (1996)); and the results of quasi-3-D sediment transport modeling.

Sediment transport calculations were completed with COSMOS, which is a deterministic numerical model for the simulation of coastal processes. Each of the processes is evaluated at approximately 250 finite difference calculation points across the profile. The various individual predictive phases of COSMOS, as well as the integrated model, have been extensively tested against both laboratory and field data (see Southgate and Nairn (1993), and Naim and Southgate (1993)). The model is described in more detail in Parson, Morang, and Nairn (1996).

The remainder of the chapter describes an investigation of the geomorphology of the study area through a review of nearshore profile evolution.

\section{Results of the Alongshore Sediment Transport Calculations}

\section{Single grain size across the profile}

This section describes the results of the average annual alongshore sediment transport calculations that were made for each profile line using grain sizes of $0.2 \mathrm{~mm}, 0.4 \mathrm{~mm}$, and $2 \mathrm{~mm}$ with the original version of COSMOS-2D. Profile line locations are shown in Figure 3.

Input for the calculation of average annual alongshore transport consists of a list of representative wave conditions (wave height, period, and direction) and durations (i.e., number of hours per year for each condition). This list was derived from the percent occurrence tables of height and period by direction 
from the WIS hindcast (1956-1987). Each wave condition from the percent occurrence tables was run four times with the COSMOS model to represent four different lake levels (with the duration for each wave condition factored by the fraction of time associated with each of the four representative lake level conditions). Each input wave and water level file consisted of approximately 1,000 conditions.

For calculations of average annual alongshore sediment transport, the COSMOS-2D numerical model assumes that the profile shape remains fixed (i.e., profile changes due to cross-shore or alongshore sediment transport are not computed). The selection of input profiles is discussed in Parson, Morang, and Nairn (1996).

Output from these runs consists of a description of the northerly and southerly sediment transport components across each profile. Net alongshore transport across the profile is calculated from the two components and total transport for the entire profile is also calculated. Net alongshore sediment transport values are given for each run in Table 3. Positive sediment transport values represent transport to the south. All of the predicted average annual net sediment transport values are directed to the south. Distributions of the average annual net alongshore transport across each profile for the three grain sizes are given in Figures 5, 6, and 7. While the net transport values for the 0- to 2 -mm runs fall in the range of approximately 70,000 to $80,000 \mathrm{~m}^{3} /$ year directed toward the south, a review of the southward and northward components reveals that the transport is much reduced for the profiles with a revetment (i.e., R14 to R23, excluding R22). The southward directed transport component ranges from $375,328 \mathrm{~m}^{3}$ at Line $\mathrm{R} 8$ to $170,794 \mathrm{~m}^{3} /$ year at $\mathrm{R} 14$. These differences in predicted transport rates are related directly to the profile shape since the same profile azimuth was assumed for each line (and since the same wave input was used for each line). Therefore, the low predicted values at Lines R14 and R23 (and to a lesser extent, R17) are a direct result of the deeper profiles at these locations (i.e., due to the absence of a beach at the toe of revetment structures). For Line R12, the peak transport occurs along the inner beach with a secondary peak over the first large bar. Line R14 results show that the peak transport occurs over the first bar offshore of the toe of the revetment.

Parson, Morang, and Nairn (1996) noted that the prefill beach sediment had a composite $d_{50}$ of about $0.3 \mathrm{~mm}$ and that the natural sediment (i.e., unaltered by beach nourishment) may be best represented by a $\mathrm{d}_{50}$ of $0.4 \mathrm{~mm}$. Therefore, a second set of alongshore transport calculations were performed with a $\mathrm{d}_{50}$ of $0.4 \mathrm{~mm}$. The results are summarized in Table 3 and presented in Figure 6. For the important southward directed transport component, the predicted values range from $159,500 \mathrm{~m}^{3} /$ year at Line $\mathrm{R} 9$ to $79,900 \mathrm{~m}^{3} /$ year at Line R14. This range of values corresponds more closely to the $84,000 \mathrm{~m}^{3} /$ year which was estimated by USACE (1973) to be trapped on the north side of the harbor. One would expect similar values for profiles located north of the harbor. Sediment trapped on the north side of the harbor is derived entirely from the southward-directed transport component (i.e., waves 


\begin{tabular}{|c|c|c|c|c|c|c|c|c|c|}
\hline \multicolumn{10}{|c|}{$\begin{array}{l}\text { Table } 3 \\
\text { 2-D COSMOS Modeling, St. Joseph Harbor, Michigan }\end{array}$} \\
\hline \multirow[b]{3}{*}{ Protile } & \multicolumn{9}{|c|}{ Average Annual Alongshore Sediment Transport } \\
\hline & \multicolumn{3}{|c|}{$0.2 \mathrm{~mm}$} & \multicolumn{3}{|c|}{$0.4 \mathrm{~mm}$} & \multicolumn{3}{|c|}{$2.0 \mathrm{~mm}$} \\
\hline & North & South & Net & North & South & Net & North & South & Net \\
\hline 8 & $-306,278$ & 375,328 & 69,050 & $-139,824$ & 154,371 & 14,548 & $-50,415$ & 59,400 & 8,985 \\
\hline 9 & $-291,765$ & 366,579 & 77,814 & $-135,758$ & 159,492 & 23,733 & $-44,893$ & 55,421 & 10,528 \\
\hline 10 & $-263,469$ & 339,963 & 81,032 & $-122,982$ & 148,291 & 25,309 & $-40,369$ & 46,205 & 5,836 \\
\hline 11 & $-282,591$ & 353,817 & 71,667 & $-131,671$ & 154,095 & 22,424 & $-42,284$ & 47,180 & 4,896 \\
\hline 12 & $-283,712$ & 355,381 & 71,669 & $-130,454$ & 150,601 & 20,147 & $-44,679$ & 48,856 & 4,176 \\
\hline 14 & $-100,086$ & 170,794 & 70,708 & $-51,092$ & 79,898 & 28,705 & $-16,702$ & 24,592 & 7,890 \\
\hline 17 & $-165,290$ & 243,799 & 78,509 & $-86,394$ & 118,091 & 31,696 & $-28,008$ & 34,839 & 6,831 \\
\hline 20 & $-149,609$ & 255,142 & 105,533 & $-79,146$ & 119,323 & 40,176 & $-25,454$ & 35,084 & 9,629 \\
\hline 22 & $-259,066$ & 336,333 & 77,266 & $-124,627$ & 149,683 & 25,506 & $-45,283$ & 50,678 & 5,395 \\
\hline 23 & $-155,016$ & 231,740 & 76,724 & $.75,257$ & 104,680 & 29,422 & $-24,614$ & 32,392 & 7,777 \\
\hline
\end{tabular}

from the south have little or no effect on the sediments trapped in the shadow of the north jetty).

Alongshore sediment transport calculations were performed for a $\mathrm{d}_{50}$ of $2.0 \mathrm{~mm}$ in the final series of these runs. The results are summarized in Table 3 and presented in Figure 7. Importantly, these findings indicate that only as little as 50 percent of the coarse sediment eroded from the feeder beach would make its way past Line R23 and south of the study area. The remaining 50 percent of the coarse sand eroded from the feeder beach is probably deposited in the depression located offshore of the MDOT and railway revetments.

\section{Multiple grain sizes across a profile}

The COSMOS-2D model was upgraded to simulate multiple grain sizes across a beach profile and alongshore sediment transport calculations were redone for Lines R12 and R14. A d 50 of $0.2 \mathrm{~mm}$ was assumed for the offshore sediments of both profiles, with a gradual coarsening from $0.2 \mathrm{~mm}$ at the swash zone to $2.0 \mathrm{~mm}$ at the shoreline.

Results for the single $d_{50}$ and multiple $d_{50}$ 's are compared in Table 4. At Line $\mathrm{R} 12$, the COSMOS-2D model tests with a multiple grain size resulted in a 25-percent reduction of northerly and southerly transport from the $0.2-\mathrm{mm}$ results of the first investigation. This is attributed to the coarsening of the 


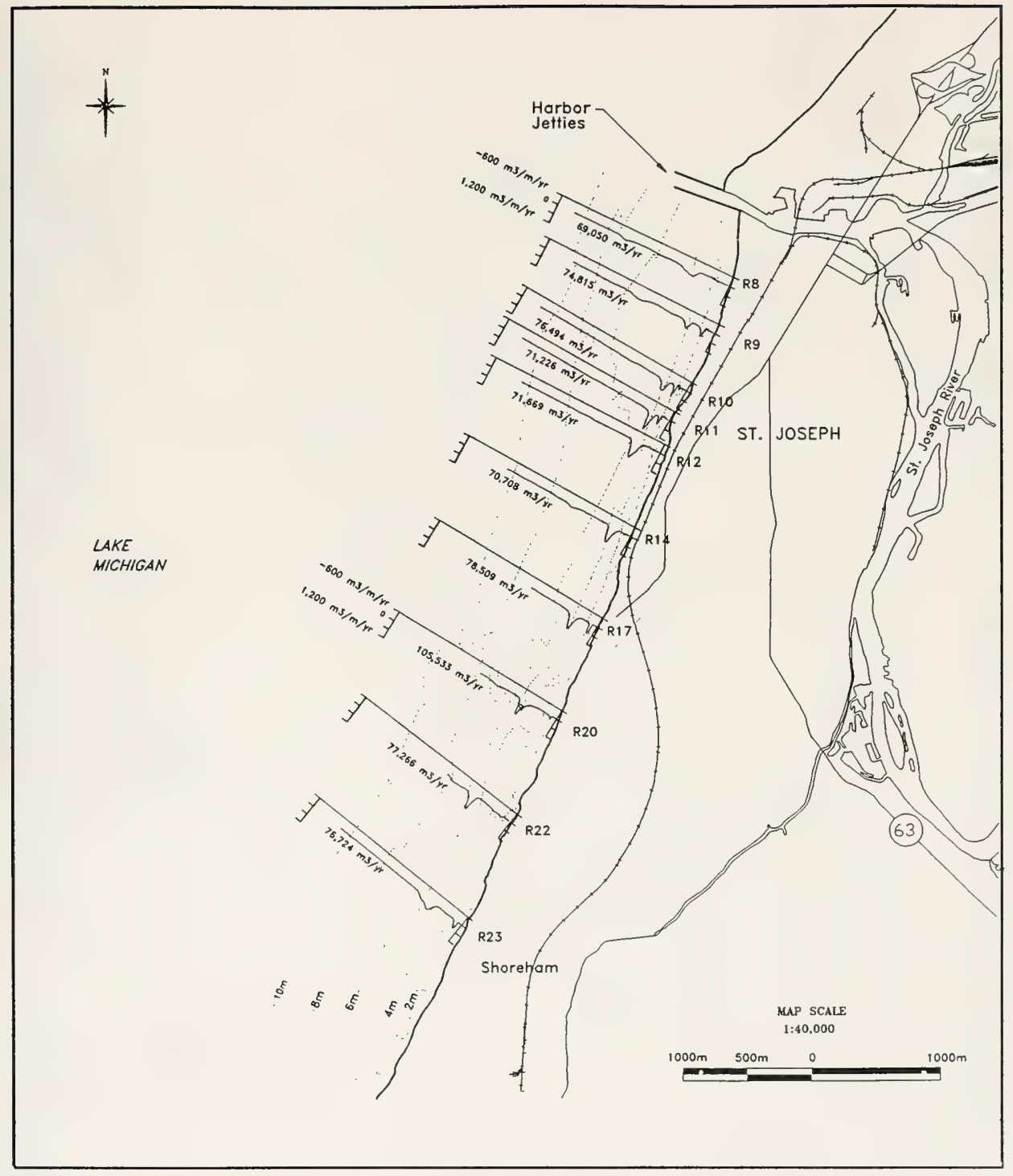

Figure 5. Net annual alongshore transport $\left(d_{50}=0.2 \mathrm{~mm}\right)$ 


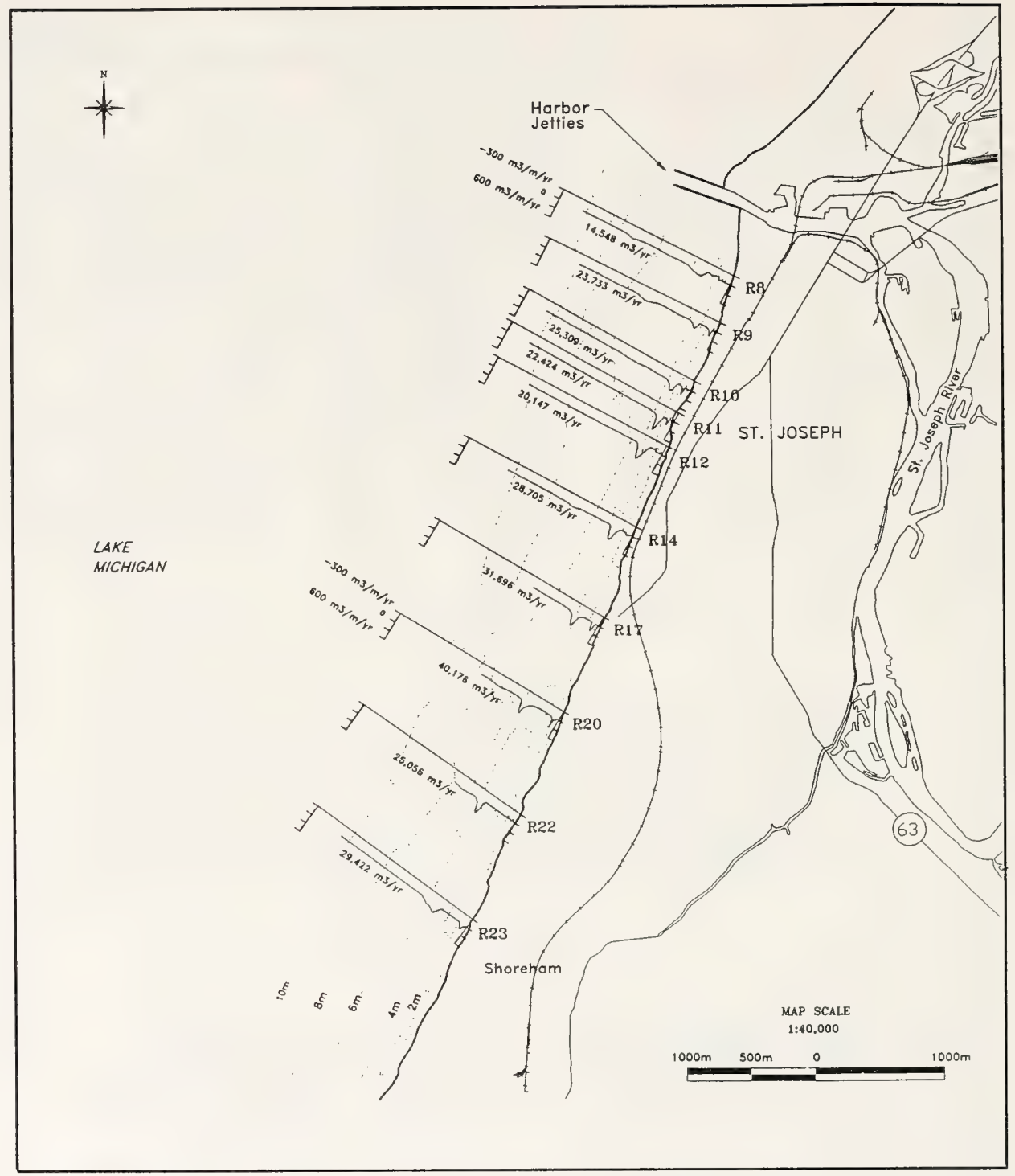

Figure 6. Net annual alongshore transport $\left(d_{50}=0.4 \mathrm{~mm}\right)$ 


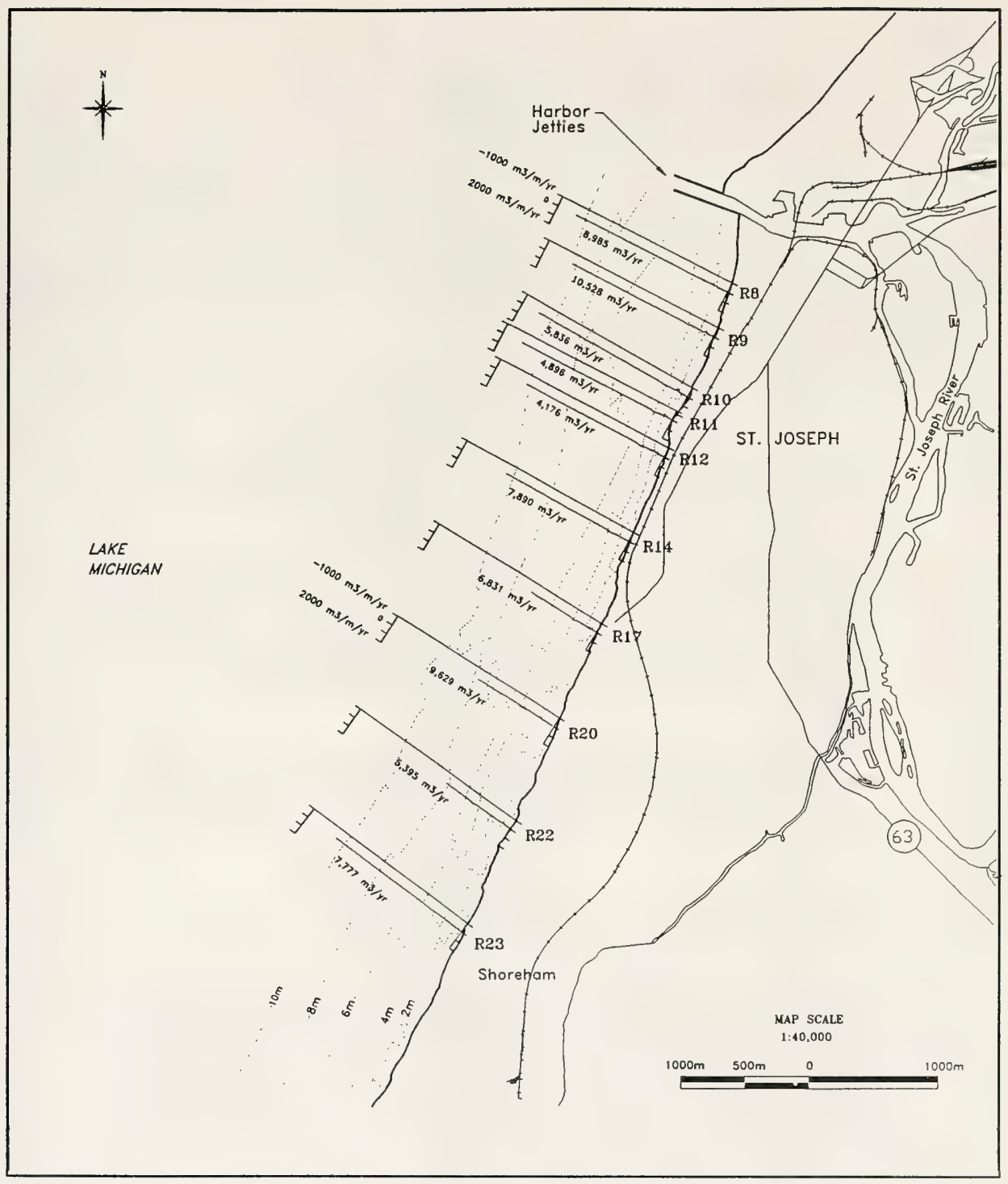

Figure 7. Net annual alongshore transport $\left(d_{50}=2.0 \mathrm{~mm}\right)$ 


\section{Table 4 \\ Average Annual Alongshore Sediment Transport (WIS M50) \\ Results from Single Grain Size and Multiple d50's}

\begin{tabular}{|c|c|c|c|c|c|c|c|c|c|c|c|c|}
\hline \multirow[b]{3}{*}{ Profile } & \multicolumn{12}{|c|}{ Average Annual Alongshore Sediment Transport } \\
\hline & \multicolumn{3}{|c|}{$0.2 \mathrm{~mm}$} & \multicolumn{3}{|c|}{$0.4 \mathrm{~mm}$} & \multicolumn{3}{|c|}{$2.0 \mathrm{~mm}$} & \multicolumn{3}{|c|}{$\begin{array}{l}\text { Offshore d50 }=0.2 \mathrm{~mm} \\
\text { Beach d50 }=2.0 \mathrm{~mm}\end{array}$} \\
\hline & $\begin{array}{l}\text { To the } \\
\text { South }\end{array}$ & $\begin{array}{l}\text { To the } \\
\text { North }\end{array}$ & Net & $\begin{array}{l}\text { To the } \\
\text { South }\end{array}$ & $\begin{array}{l}\text { To the } \\
\text { North }\end{array}$ & Net & $\begin{array}{l}\text { To the } \\
\text { South }\end{array}$ & $\begin{array}{l}\text { To the } \\
\text { North }\end{array}$ & Net & $\begin{array}{l}\text { To the } \\
\text { South }\end{array}$ & $\begin{array}{l}\text { To the } \\
\text { North }\end{array}$ & Net \\
\hline R12 & 355,381 & $-283,712$ & 71,669 & 150,601 & $-130,454$ & 20,147 & 48,856 & $-44,679$ & 4,176 & 265,388 & $-213,467$ & 51,921 \\
\hline R14 & 170,794 & $-100,086$ & 70,708 & 78,898 & $-51,092$ & 28,705 & 24,592 & $-16,702$ & 7,890 & 154,524 & $-97,413$ & 57,111 \\
\hline
\end{tabular}

Note: 1. Positive transport is directed to the south.

2. Transport calculations from average annual waves (WIS Station M50).

sediment in the swash zone and beach for the new model runs (i.e., the coarse sediment has a reduced potential for transport).

The ability of COSMOS-2D to estimate alongshore sediment transport rates with multiple $\mathrm{d}_{50}$ 's improves the accuracy of the predictions for St. Joseph by representing the natural distribution of sediment across the nearshore and beach zones. In general, the $0.2-\mathrm{mm}$ results in Table 4 were reduced by 25 percent when coarse sediment was considered. For the protected sections of the St. Joseph shore (such as the MDOT revetment) where no beach exists, the reduction is less than 25 percent.

In summary, these sediment transport calculations also indicate that perhaps only 50 percent of the coarse sand which is eroded from the feeder beach area (by storms with waves from the north) can be transported out of the study area south of Line 23 .

\section{Annual variation in potential alongshore sediment transport}

To investigate variation in the wave climate, yearly estimates of wave energy and average direction were calculated for selected years from the WIS data (see Figures 8 and 9). Figure 8 shows a large annual variation in total wave energy ranging from a maximum in 1977 of $46,000 \mathrm{~m}^{2} / \mathrm{s}$ to a minimum in 1986 of $17,000 \mathrm{~m}^{2} / \mathrm{s}$. The average annual wave direction presented in Figure 9 also shows considerable variation. From the 32 years of data, seven individual years were selected to represent the wide range of actual combinations of wave energy and direction.

Alongshore sediment transport rates were calculated with COSMOS-2D for profiles R12 (sandy shore) and R14 (revetment). Multiple grain sizes were considered for both profiles to represent the actual field conditions at St. Joseph. Results are presented in Table 5. In 1964, the average wave 


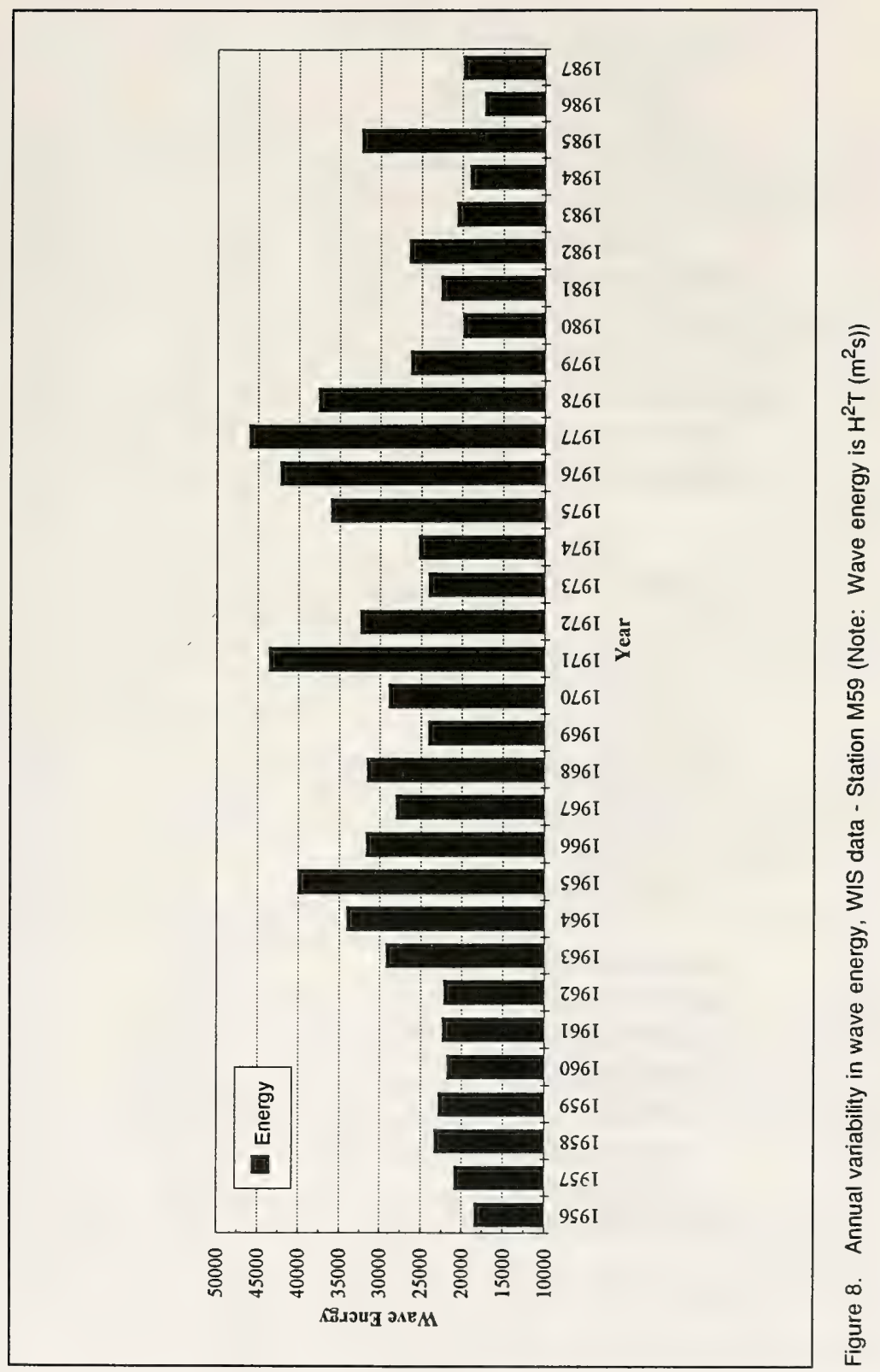




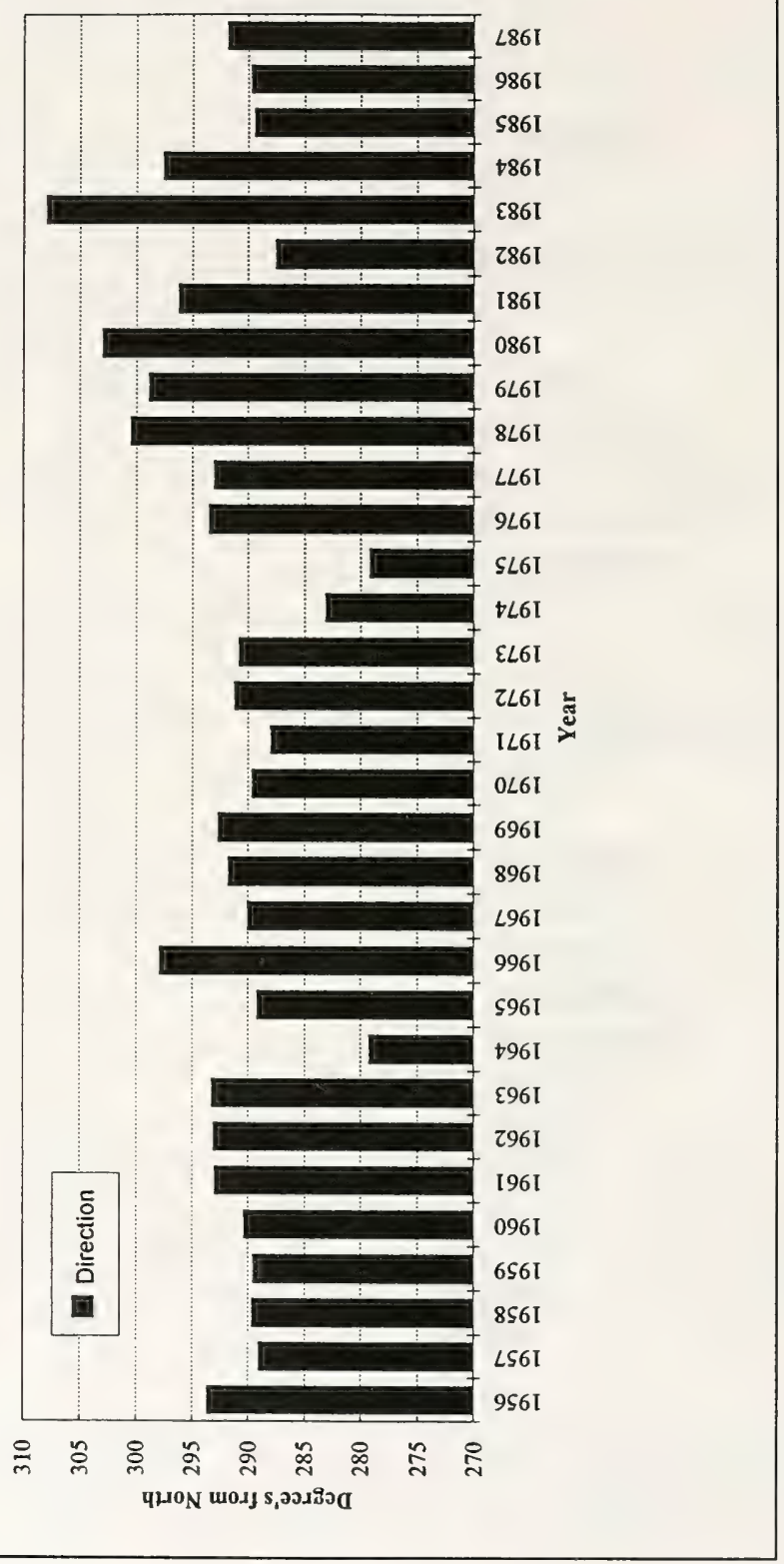

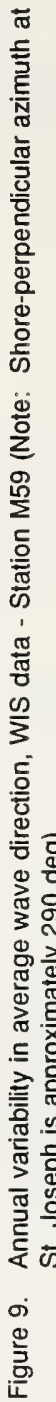




\begin{tabular}{|c|c|c|c|c|c|c|c|c|}
\hline \multicolumn{9}{|c|}{$\begin{array}{l}\text { Table } 5 \\
\text { Annual Variability in Potential Alongshore Transport (1992 Profiles) }\end{array}$} \\
\hline \multirow[b]{2}{*}{ Year } & \multirow{2}{*}{$\begin{array}{l}\text { Avg. } \\
\text { Direction } \\
\text { (deg from } N \text { ) }\end{array}$} & \multirow[b]{2}{*}{$\begin{array}{l}\text { Wave } \\
\text { Energy } \\
\left(\mathrm{m}^{2} / \mathrm{s}\right)\end{array}$} & \multicolumn{3}{|c|}{ R12 (1992) } & \multicolumn{3}{|c|}{ R14 (1992) } \\
\hline & & & $\begin{array}{l}\text { To the } \\
\text { South }\left(m^{3}\right)\end{array}$ & $\begin{array}{l}\text { To the } \\
\text { North }\left(\mathrm{m}^{3}\right)\end{array}$ & Net $\left(m^{3}\right)$ & $\begin{array}{l}\text { To the } \\
\text { South }\left(\mathrm{m}^{3}\right)\end{array}$ & $\begin{array}{l}\text { To the } \\
\text { North }\left(m^{3}\right)\end{array}$ & Net $\left(m^{3}\right)$ \\
\hline 1964 & 279 & 34,000 & 375,350 & $-379,867$ & $-4,517$ & 231,993 & $-196,583$ & 35,410 \\
\hline 1965 & 289 & 40,000 & 625,108 & $-433,064$ & 192,044 & 442,246 & $-227,578$ & 214,668 \\
\hline 1971 & 287 & 44,000 & 654,857 & $-481,967$ & 172,890 & 482,302 & $-298,929$ & 183,373 \\
\hline 1974 & 283 & 25,000 & 376,879 & $-329,032$ & 47,847 & 247,197 & $-162,939$ & 84,258 \\
\hline 1977 & 293 & 46,000 & 741,016 & $-382,582$ & 358,434 & 493,753 & $-226,542$ & 267,211 \\
\hline 1983 & 308 & 21,000 & 364,927 & $-164,594$ & 200,333 & 236,383 & $-84,622$ & 151,761 \\
\hline 1986 & 290 & 17,000 & 235,452 & $-135,719$ & 99,733 & 129,425 & $-48,728$ & 80,697 \\
\hline
\end{tabular}

direction was 279 deg from north, which is close to the shore-perpendicular profile azimuth selected for the profiles at St. Joseph. Consequently, the estimated net transport for 1964 was very close to zero. Of the 7 years selected from the WIS data at M59, 1977 recorded the maximum wave energy $\left(46,000 \mathrm{~m}^{2} / \mathrm{s}\right)$ and the highest net southerly transport rate component of $382,600 \mathrm{~m}^{3} /$ year.

Although the net transport rates for R12 and R14 are fairly similar, the southerly and northerly components at R14 are much lower than the results for $\mathrm{R} 12$, perhaps due to the deeper profile offshore of the revetment at R14.

\section{Historic variability in potential alongshore sediment transport related to profile change}

Sediment transport calculations were completed at three historical profile lines, Nos. 2, 3, and 4, to determine the influence of long-term profile change (Figure 10). The profiles were generated from the 3-D surfaces created from the historic bathymetry. Selection of the four profile locations was based on the following assumptions about the nearshore conditions and profile evolution prior to the comparison of the data:

a. Line 1. Updrift cohesive profile (no influence from fillet/harbor jetties - representative of natural conditions or background erosion rate).

b. Line 2. Updrift fillet profile (influenced by harbor jetties).

c. Line 3. Downdrift cohesive profile (reduced sediment supply - influenced by the harbor jetties). 


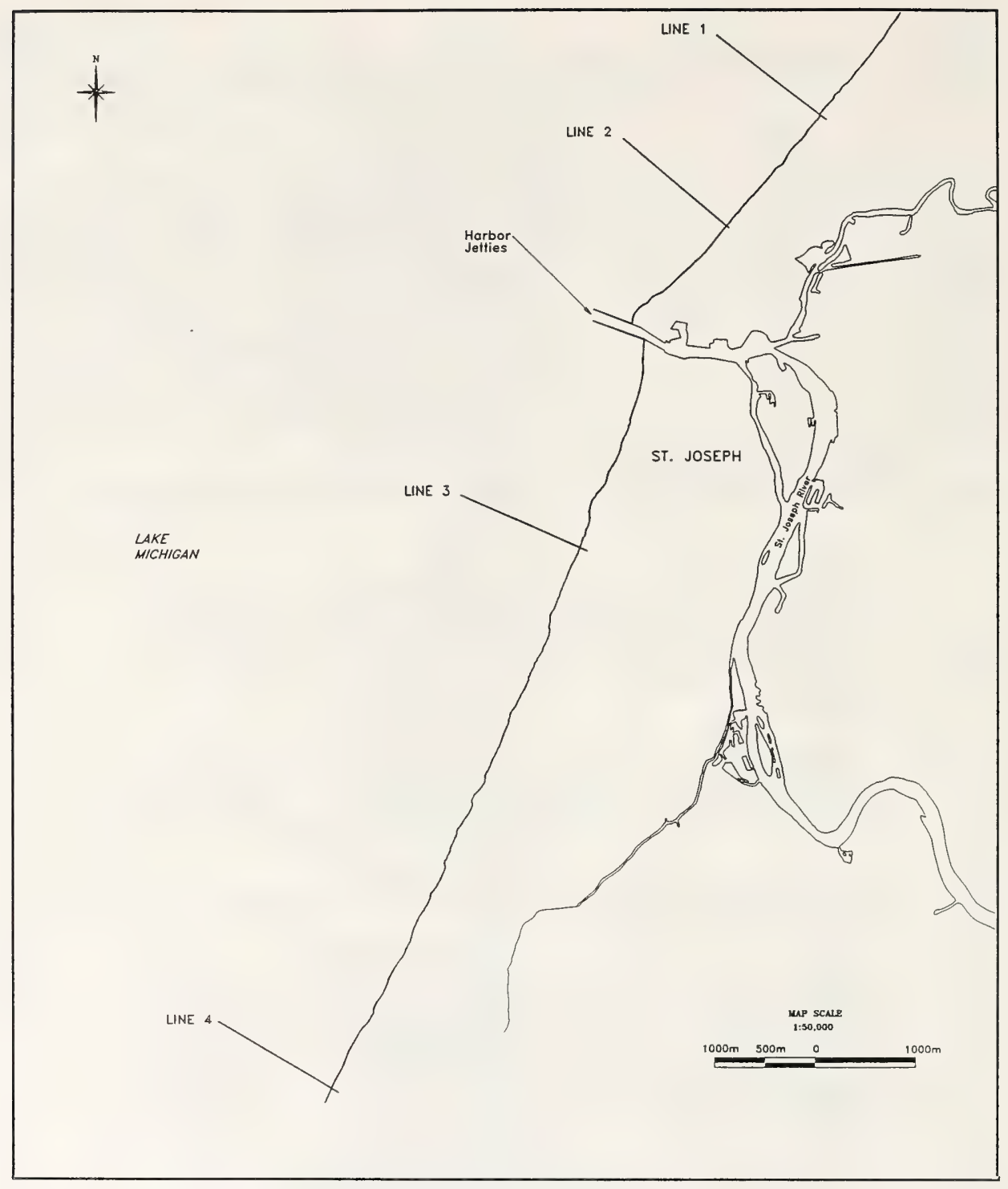

Figure 10. Location of historic profile comparisons 
d. Line 4. Downdrift cohesive profile (not influenced by reduced sediment supply from the north - representative of natural conditions or background erosion rate).

Model runs were completed for profiles from the four available bathymetric surveys: 1945/46, 1964/65, 1991, and 1995. Changes in these profiles are discussed in a later section titled "Trends in Profile Change" (page 57), and the changes are illustrated in Figures 11 to 13 . The results of the model runs are summarized in Table 6.

Decreased depths at Line 2 in the vicinity of the depositional fillet beach have increased the potential for alongshore sediment transport because the zone of breaking waves is wider. However, this increase may be offset by the change in shoreline and contour orientation at this location.

The large depression offshore of R12 and R14 and the associated steeper nearshore slopes at Line 3 resulted in a 24-percent reduction in southerly potential transport from 259,000 to $198,000 \mathrm{~m}^{3} /$ year from 1945 to 1995 (see Table 6). At Line 3 the northerly transport component was reduced by 32 percent from $207,000 \mathrm{~m}^{3} /$ year in 1945 to $142,000 \mathrm{~m}^{3} /$ year in 1995 .

At Line 4, located $8.2 \mathrm{~km}$ south of the harbor jetties, the predicted transport rates were also much lower for the 1995 profile (see Table 7). From 1945 to 1995 , southerly transport decreased 31 percent and northerly transport decreased by 41 percent.

In summary, long-term profile changes at St. Joseph have influenced the potential for northerly and southerly alongshore sediment transport. At the north fillet beach, the reduction in nearshore depths due to deposition has increased the potential for sediment transport. South of the harbor jetties, the deeper nearshore profiles off the revetment and the unprotected shores further to the south have significantly reduced the potential for northerly and southerly transport.

\section{Bypassing and channel infilling at St. Joseph Harbor}

Since the construction of the jetties in 1903, the fillet beach deposits north and south of the harbor have increased in size, resulting in increased potential for channel infilling during northerly and southerly wave attack. Profile data from the detailed 1995 bathymetry were used as input for the COSMOS-2D model to assess the existing potential for channel bypassing and/or infilling.

Annual rates of alongshore transport were calculated beyond the end of the north and south jetties. Landward of the channel entrance, the harbor jetties due to their sheet-pile construction, were assumed to be complete barriers to alongshore transport. The average annual potential for channel infilling from the north was estimated to be $15,000 \mathrm{~m}^{3} /$ year (see Figure $14 \mathrm{a}$ ) based on the 


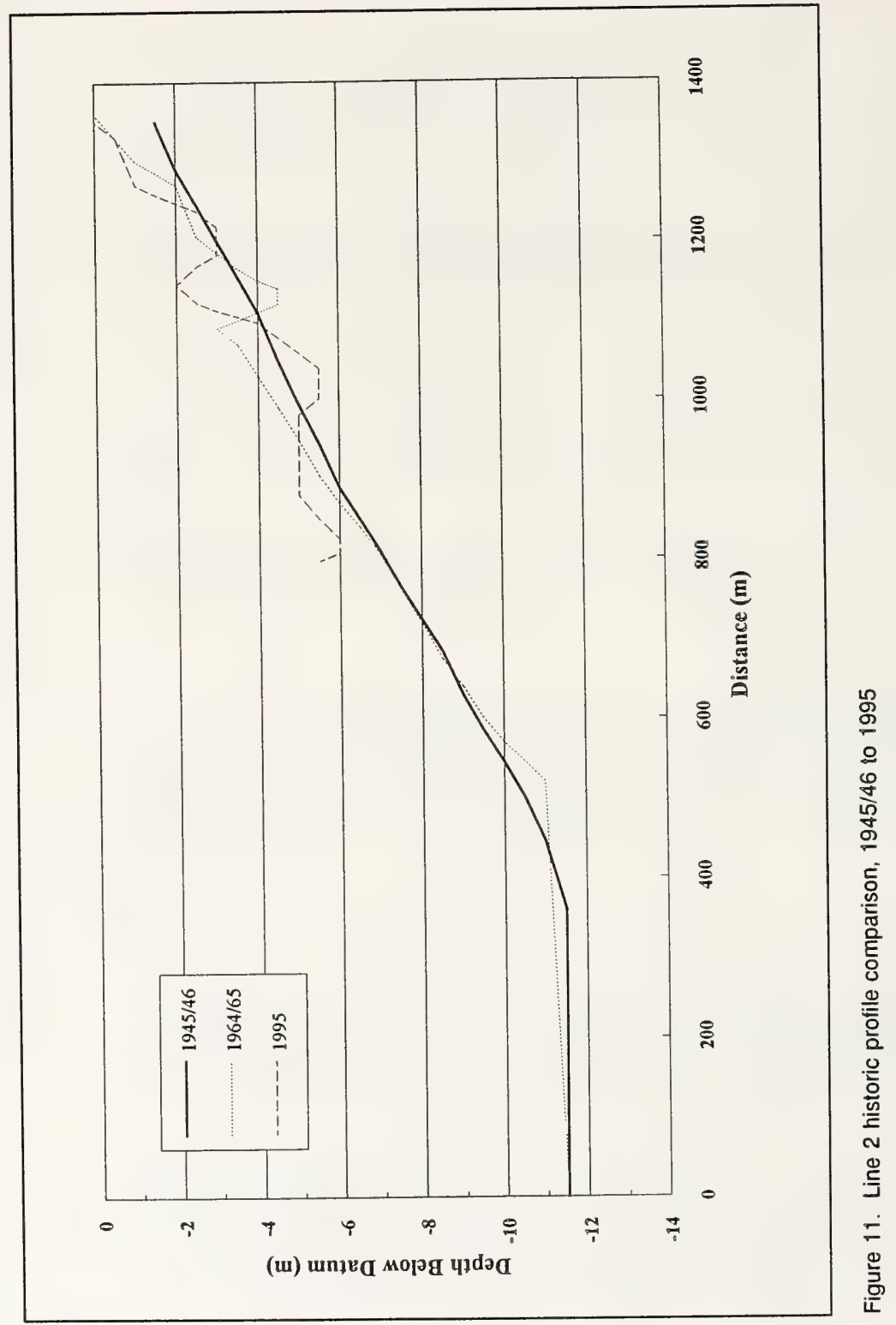




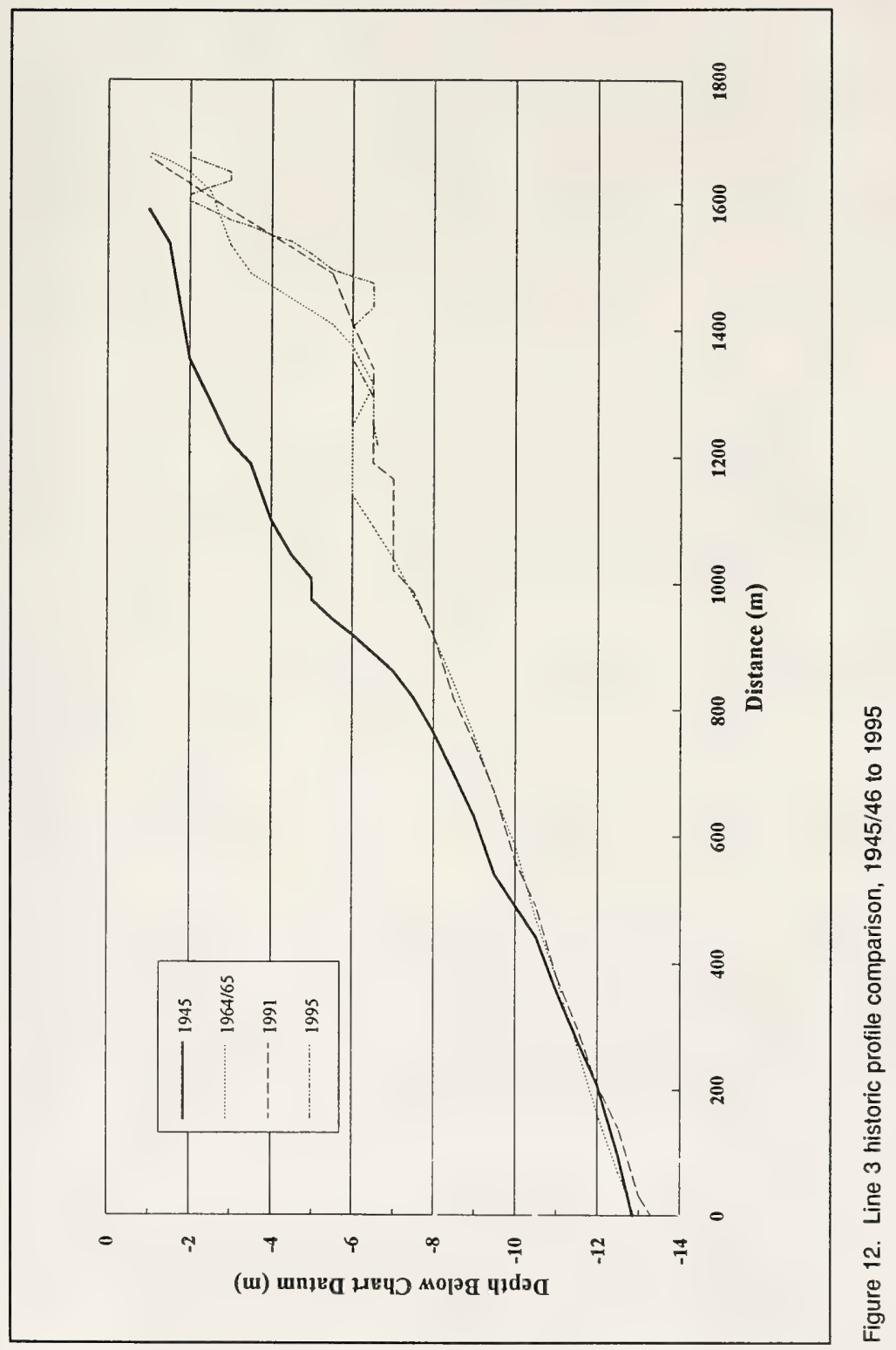




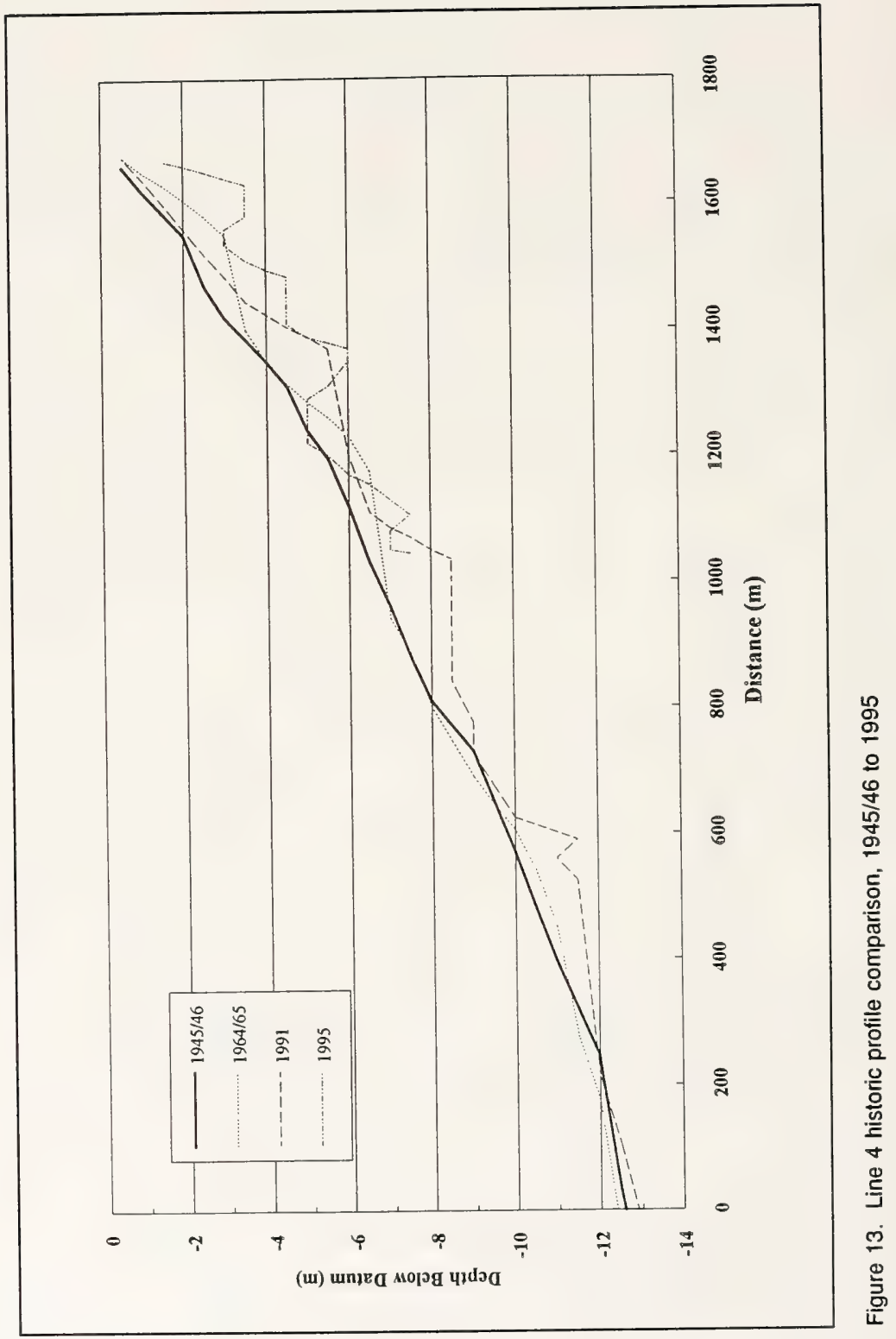




\begin{tabular}{|c|c|c|c|c|c|c|c|c|c|}
\hline \multirow{2}{*}{ Profile } & \multicolumn{3}{|c|}{ Line $2(1,350 \mathrm{~m}$ North of Jetties) } & \multicolumn{3}{|c|}{ Line $3(2,200 \mathrm{~m}$ South of Jetties) } & \multicolumn{3}{|c|}{ Line $4(8,200 \mathrm{~m}$ South of Jelties) } \\
\hline & $\begin{array}{l}\text { To the } \\
\text { South }\left(m^{3}\right)\end{array}$ & $\begin{array}{l}\text { To the } \\
\text { North }\left(\mathrm{m}^{3}\right)\end{array}$ & $\begin{array}{l}\mathrm{Net} \\
\left(\mathrm{m}^{3}\right)\end{array}$ & $\begin{array}{l}\text { To the } \\
\text { South }\left(m^{3}\right)\end{array}$ & $\begin{array}{l}\text { To the } \\
\text { North }\left(\mathrm{m}^{3}\right)\end{array}$ & Net $\left(\mathrm{m}^{3}\right)$ & $\begin{array}{l}\text { To the } \\
\text { South }\left(\mathrm{m}^{3}\right)\end{array}$ & $\begin{array}{l}\text { To the } \\
\text { North }\left(\mathrm{m}^{3}\right)\end{array}$ & $\begin{array}{l}\text { Net } \\
\left(m^{3}\right)\end{array}$ \\
\hline 1945 & 198,433 & $.140,006$ & 58,427 & 259,371 & $-207,176$ & 52,195 & 252,442 & $-197,966$ & 54,476 \\
\hline 1965 & 227,909 & $-170,208$ & 57,701 & 215,441 & $-158,792$ & 56,649 & 234,210 & $-176,583$ & 57,627 \\
\hline 1991 & - & - & - & 200,708 & $-145,711$ & 54,997 & 240,022 & $-186,383$ & 53,639 \\
\hline 1995 & 240,158 & $-184,706$ & 55,191 & 198,293 & $-141,720$ & 56,573 & 173,002 & $-116,738$ & 56,264 \\
\hline
\end{tabular}

1995 bathymetry and the annual average wave climate from 1956 to 1987 at Station M59.

Due to lower rates of northerly transport, the south fillet beach is smaller than the north fillet beach. The potential rate of annual channel infilling during southerly wave attack is estimated to be $8,500 \mathrm{~m}^{3} / \mathrm{year}$ (see Figure 14b). The combined annual rate of channel infilling is estimated at $23,500 \mathrm{~m}^{3} /$ year. Annual variations in wave energy could result in much higher channel infilling in any given year.

The rate of natural bypassing will be significantly less than the estimated potential infilling rate.

\section{Results of Cross-Shore Modeling with Multiple Grain Sizes}

With the new capabilities of the COSMOS-2D model to include multiple grain sizes for a single profile, the cross-shore model tests for Profiles R9 and $\mathrm{R} 14$ were repeated with $0.2-\mathrm{mm}$ sand offshore and $2.0-\mathrm{mm}$ sand in the nearshore and beach. Also, an additional low water level condition was considered for the 24 January 1992 storm to examine the influence of low water levels on cohesive profile exposure and bar movement. It should be noted that the multiple grain size version of COSMOS does not include the ability to simulate the mixing of grain sizes across the profile (i.e., the various grain size zones remain fixed in position).

For Profile R9, located at the feeder beach, the erosion and deposition trends predicted with the multiple grain sizes were similar to the results for a single grain size as presented in Parson, Morang, and Naim (1996) (see Figures 15 to 17). Erosion of the sand cover results in exposure of the underlying till in some areas. The width of the exposed till was not influenced by water level; however, the location of the till exposure was influenced by the different 


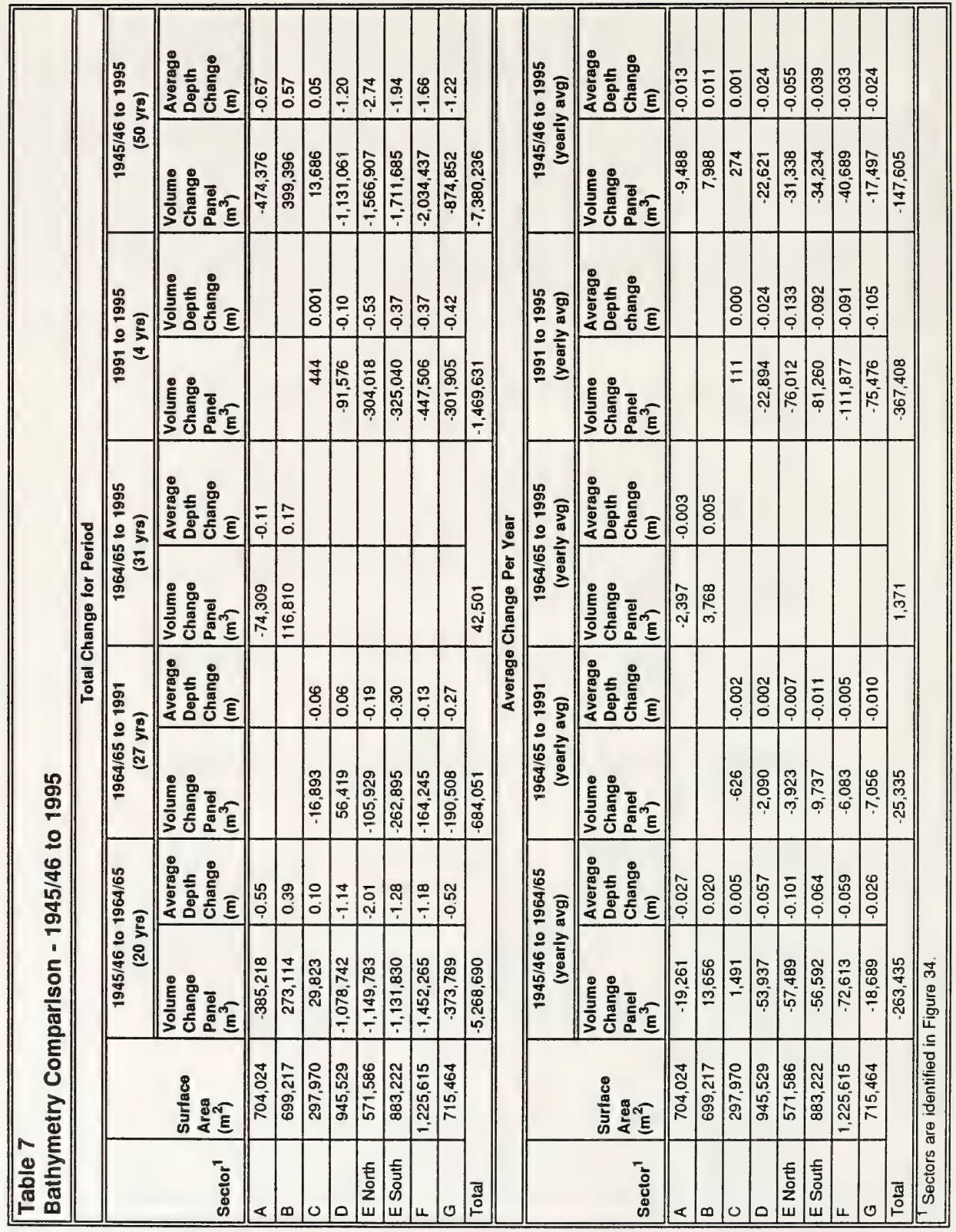



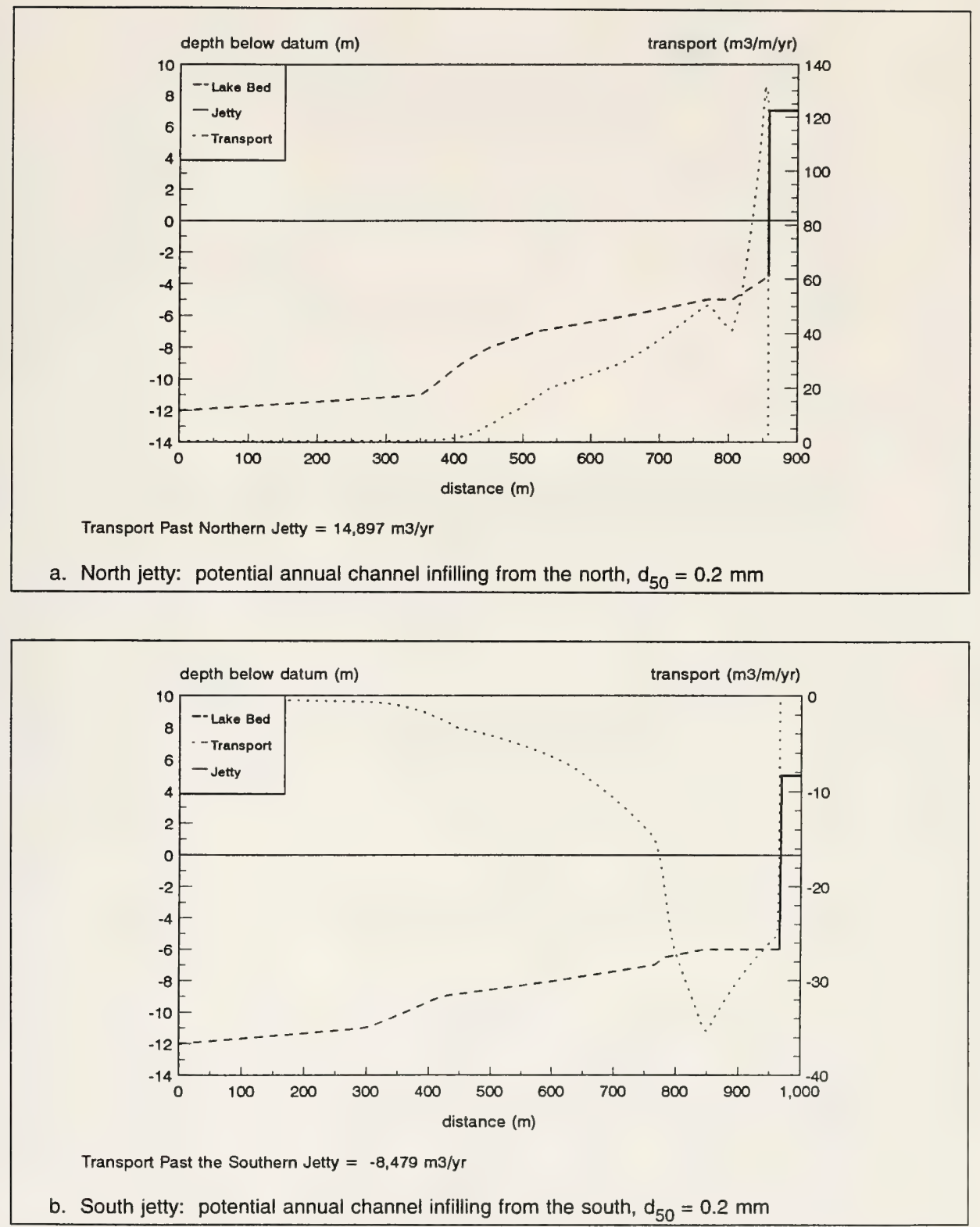

Figure 14. 1995 bathymetry and transport at harbor jetties 

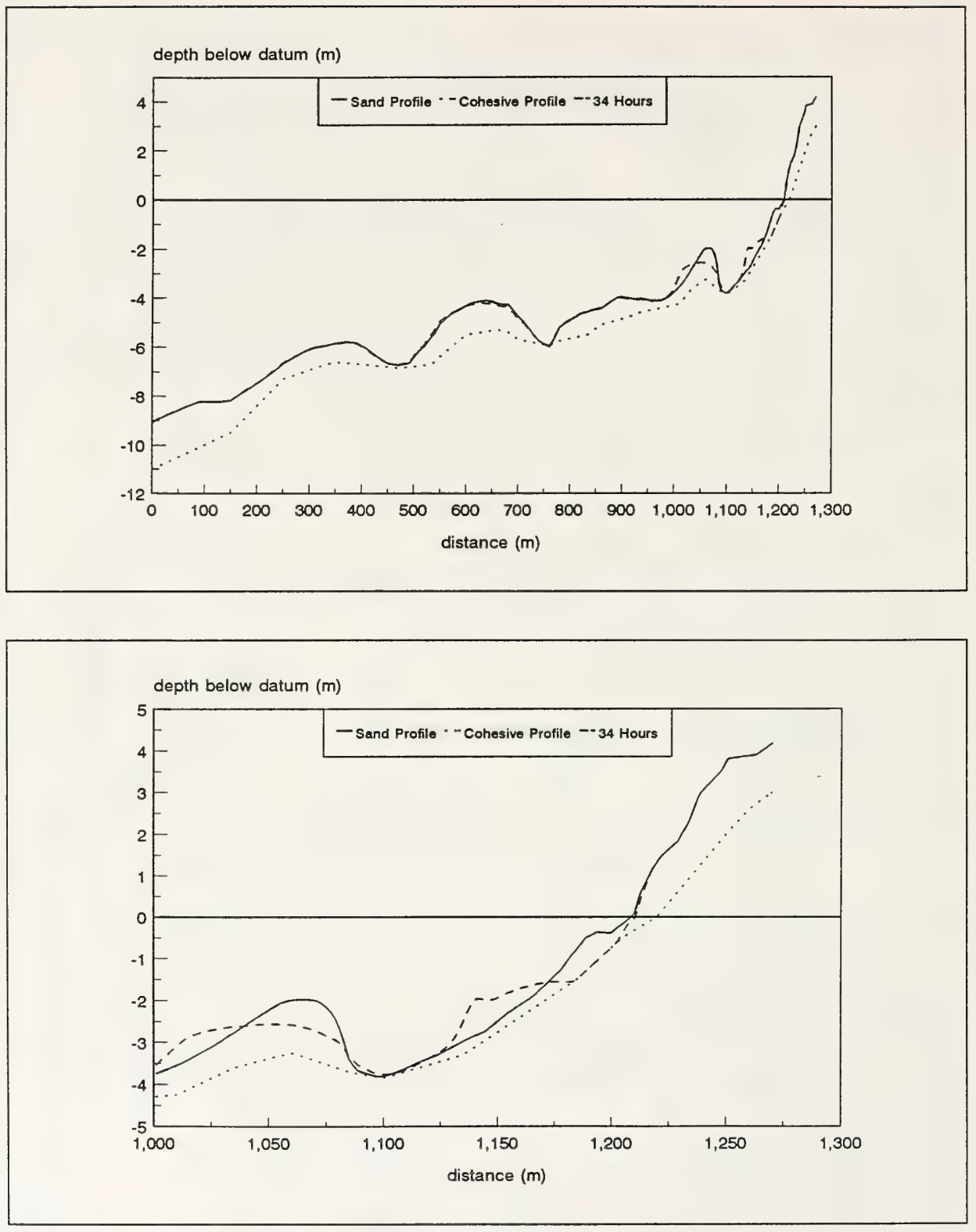

Figure 15. St. Joseph, Michigan, R9 profile change for the Jan. 24, 1992 storm, low water level. Offshore $d_{50}=0.2 \mathrm{~mm}$, beach $d_{50}=2.0 \mathrm{~mm}$ 

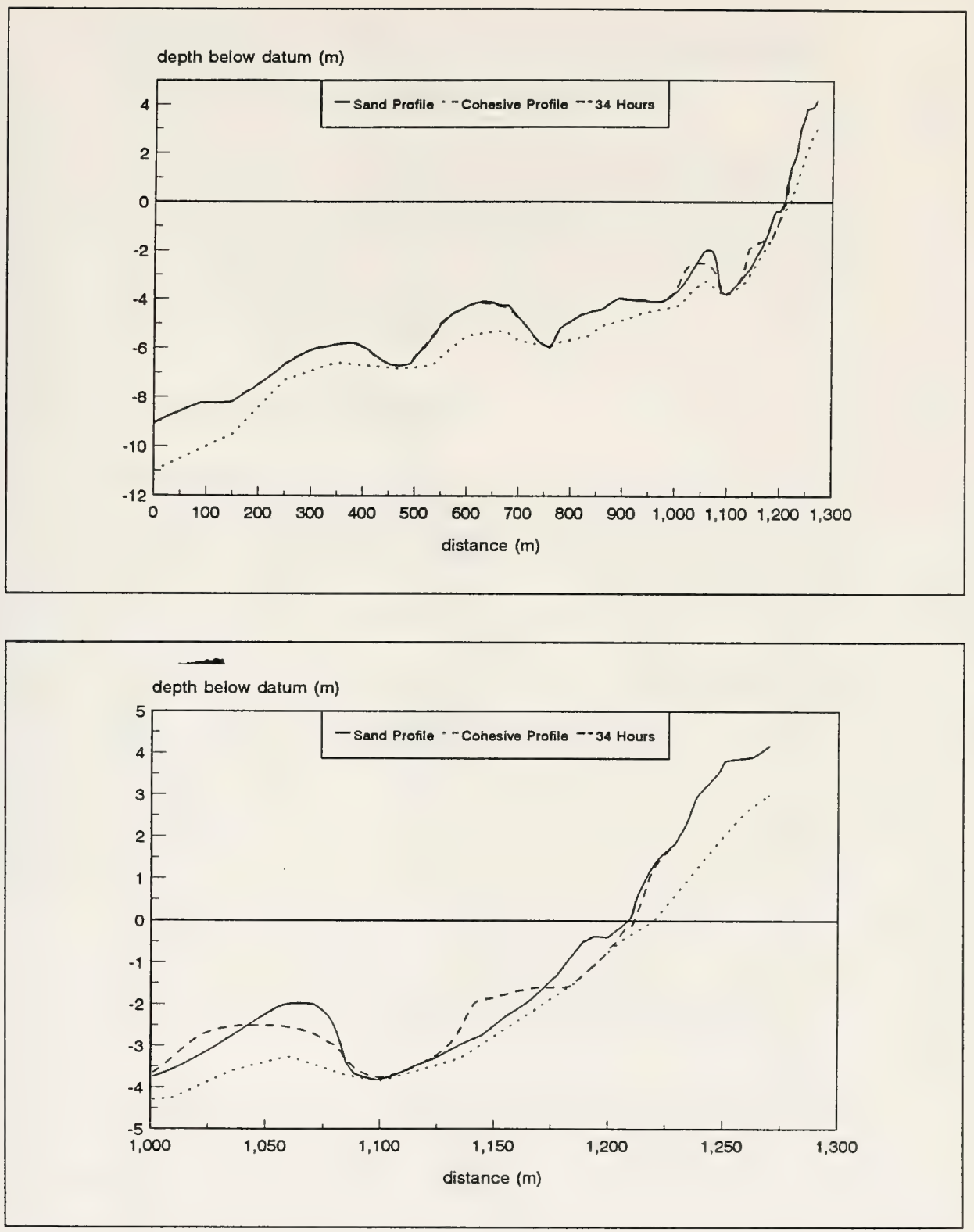

Figure 16. St. Joseph, Michigan, R9 profile change for the Jan. 24, 1992 storm, actual water level. Offshore $d_{50}=0.2 \mathrm{~mm}$, beach $d_{50}=2.0 \mathrm{~mm}$ 


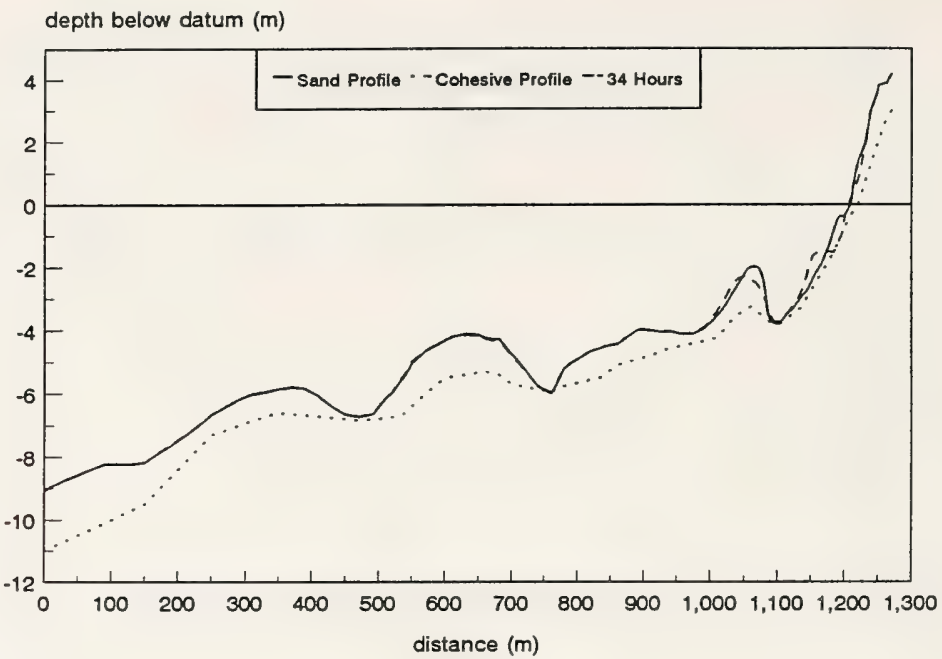

depth below datum $(\mathrm{m})$

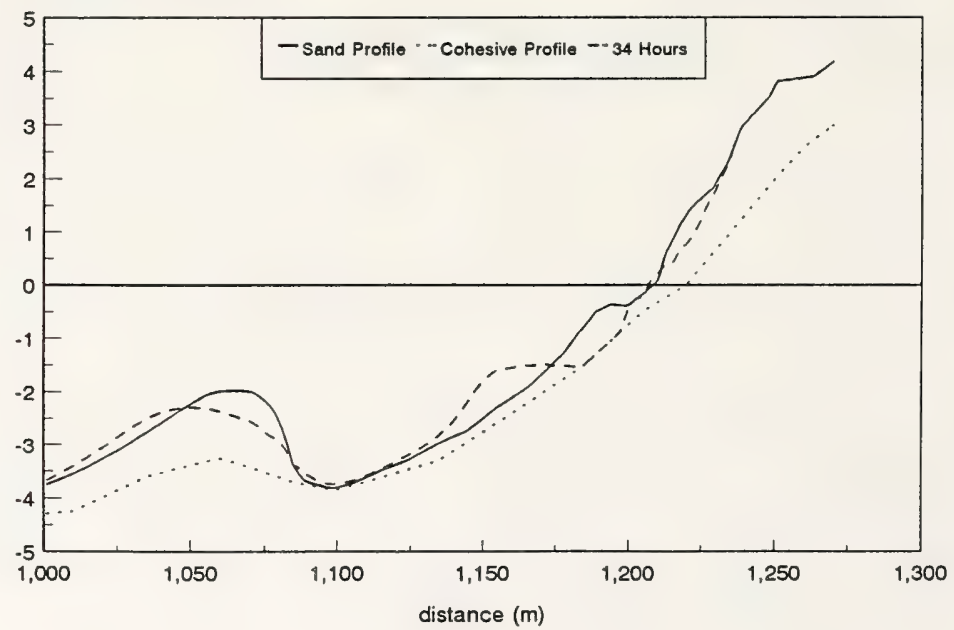

Figure 17. St. Joseph, Michigan, R9 profile change for the Jan. 24, 1992 storm, high water level. Offshore $d_{50}=0.2 \mathrm{~mm}$, beach $d_{50}=2.0 \mathrm{~mm}$ 
water levels. The presence of the coarse sand $(2.0 \mathrm{~mm})$ on the beach protected this area from significant erosion, even during high water levels. However, the zone of transition from coarse beach sediment to fine sediment offshore was vulnerable to considerable erosion.

At Line R14 the shoreline is protected by the revetment. The results of the profile response runs for an average water level are shown in Figure 18. For all water levels, there was minor erosion of the sand in the troughs between the nearshore bars. The trends in profile response for R14 with multiple sediment sizes were similar to the results presented in Parson, Morang, and Nairn (1996) for single grain sizes across the entire profile. For all three water levels, the model predicted accumulation at the toe of the revetment and minor adjustment in the position of the large bar.

\section{COSMOS-3D Modeling}

\section{Methodology}

COSMOS-3D is referred to as a quasi-3-D model because the coastal processes are more fully integrated across the profile than in the alongshore direction. The 3-D model is based on the deterministic COSMOS-2D model for the prediction of coastal processes across a nearshore profile (see Nairn (1993)). The profile model is extended to represent a 3-D situation through the linkage of 11 of the individual profile lines along the St. Joseph study area. In this model, the profiles are treated independently in a hydrodynamic sense, but are linked morphodynamically by consideration of the differential rates of alongshore transport between adjacent profiles. Although the 3-D model grid is rectilinear, the sediment is transported alongshore in a direction coincident with an input "marker depth" contour. For the runs performed as part of this investigation, two different marker depths have been utilized: (a) the most landward 2.5-m depth contour (parallel to the first large bar, which is the primary pathway for fine sediment transport) (b) the $0.5-\mathrm{m}$ depth contour, which gives the alignment of the upper beach and is the major pathway for the transport of the $2-\mathrm{mm}$ grain size. The model is only quasi-3-D and is restricted in its application to cases where the 3-D circulation is negligible or of secondary importance to the morphology change. In this respect, the St. Joseph study area, which features a relatively straight coast with parallel near-shore contours, is an ideal site for the application of COSMOS-3D.

The grid for the 3-D modeling consisted of 11 of the profile lines, with R10a excluded due to its close proximity to R10 and R11 (Figure 19). In the northern beachfill area, there was $200-$ to 300 -m spacing between profiles, while south of $\mathrm{R} 12$, the spacing was $800 \mathrm{~m}$ or more. The lines varied in length (perpendicular to the shore) between 1,000 and $1,700 \mathrm{~m}$, with about 200 calculation points describing each line. The input depth ranged from 8 to $13 \mathrm{~m}$. 

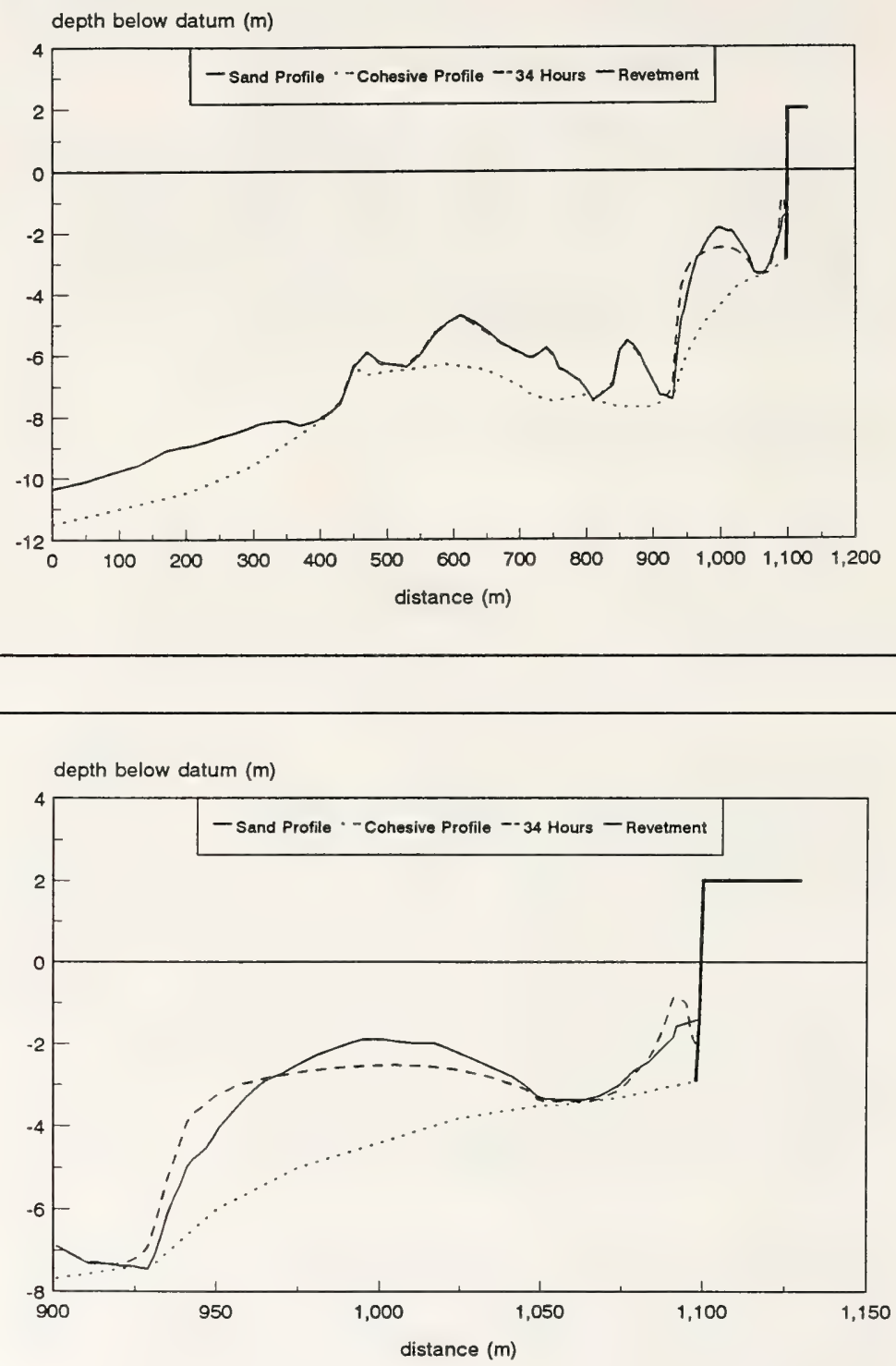

Figure 18. St. Joseph, Michigan, R14 profile change for the Jan. 24, 1992 storm, actual water level 


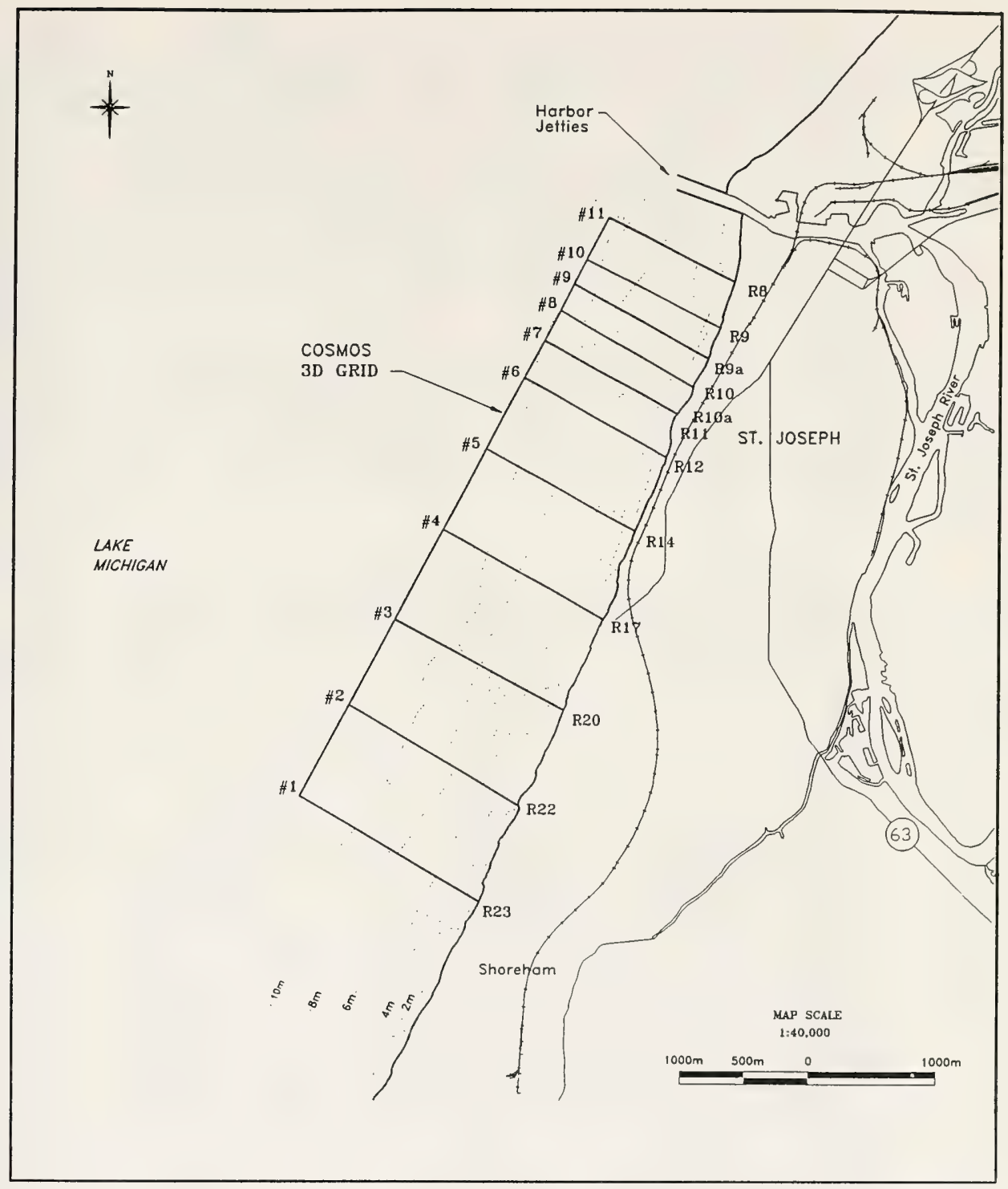

Figure 19. COSMOS 3-D setup 
Output for COSMOS-3D consists of profile change plots for each of the 11 profile lines, which are similar to the $2-\mathrm{D}$ result format. In addition, net alongshore transport for the duration of the storm is plotted. The boundary profiles at R8 in the north and R23 in the south are assumed to remain fixed in the numerical calculation scheme. The results must be considered in relation to the large profile spacing (i.e., 200 to $800 \mathrm{~m}$ ). The predicted changes to the morphology will be limited to features with lengths in the range of 200 to 800 $\mathrm{m}$ or greater. Closer alongshore spacing was not possible owing to the limited number of survey lines. Unfortunately, the 1991 bathymetry survey was not of sufficient detail to pick up the shape of nearshore bars, and therefore could not be used to supplement the profile lines for 3-D input. The SHOALS 1995 bathymetry was not available at the time the 3-D modeling was completed.

Wave and water level information can be input at each of the 11 profile lines if information is available on variations in these parameters along the shore. For this investigation, the only variation that was considered consisted of wave sheltering effects for Lines R8 and R9 during northwest wave attack (i.e., in the lee of the south jetty of the harbor entrance).

\section{General results}

Profile change predictions from the cross-shore (2-D) modeling indicated that the middle and outer sections of the surf zone (which feature one or more bars) were relatively stable over the duration of a single storm event. A series of 3-D runs were performed to investigate the morphologic response of the sand cover under the combined influence of cross-shore and alongshore sediment transport during storm events. These experiments were also specifically directed to describing the mobilization and transport of the beach nourishment and to assessing the exposure and downcutting of the underlying glacial till.

Table 8 summarizes all of the 3-D results. The three initial runs consisted of an assessment of morphologic response under pre-fill conditions, with a grain size of $0.2 \mathrm{~mm}$ for three different storm events. These storm events are described in Parson, Morang, and Nairn (1996). The 2 November 1991 event represents one of the largest storms from the southwest (in terms of wave energy) over the two hindcast periods (1956 - 1987 and 1991 - 1993). The 14 January 1992 storm featured northwest waves and was the largest storm in terms of wave energy over the two hindcast periods. In the first section of this chapter, entitled "Results of the Alongshore Sediment Transport Calculations," we concluded that net transport is directed to the south owing to the predominance of northwest storms. The 24 January 1994 event features waves which swung from southwest to northwest through the duration of the storm (with an average direction of west). This type of storm occurs frequently, and the magnitude of this particular event represents a storm that would occur once per year on average. The 24 January 1992 storm was used as input for all of the cross-shore (2-D) evaluations described in the section titled "Results of Crossshore Modeling with Multiple Grain Sizes." 


\begin{tabular}{|c|c|c|c|c|c|c|}
\hline \multicolumn{7}{|c|}{$\begin{array}{l}\text { Table } 8 \\
\text { Summary of 3-D Model Runs }\end{array}$} \\
\hline 3-D Run & Storm Event & Primary Direction & Lake Level & Fill Status & Grain Size $(\mathrm{mm})$ & Marker Depth $(m)$ \\
\hline A & 2 Nov. '91 & sw & avg. & pre & 0.2 & 2.5 \\
\hline$B$ & 14 Jan. '92 & NW & avg. & pre & 0.2 & 2.5 \\
\hline c & 24 Jan. '92 & $w$ & avg. & pre & 0.2 & 2.5 \\
\hline$D$ & 2 Nov. '91 & sw & avg. & post & 0.2 & 2.5 \\
\hline$E$ & 14 Jan. '92 & NW & avg. & post & 0.2 & 2.5 \\
\hline $\mathrm{F}$ & 24 Jan. '92 & $w$ & avg. & post & 0.2 & 2.5 \\
\hline G & 2 Nov. '91 & sw & avg. & pre & 2.0 & 2.5 \\
\hline H & 14 Jan. ' 92 & NW & avg. & pre & 2.0 & 2.5 \\
\hline 1 & 2 Nov. '91 & sw & high & pre & 0.2 & 2.5 \\
\hline $\mathrm{J}$ & 14 Jan. '92 & NW & high & pre & 0.2 & 2.5 \\
\hline $\mathrm{k}$ & 14 Jan. '92 & NW & avg. & pre & 2.0 & 0.5 \\
\hline L & 14 Jan. '92 & NW & avg. & post & 2.0 & 0.5 \\
\hline
\end{tabular}

Owing to the great number of output plots generated from the series of 3-D runs ( 11 plots for each of the 12 storms) only the profile change results from run B are presented (see Figure 20). A summary of the predicted net alongshore transport for each of the profile lines for some of the runs is given in Table 9.

\section{Runs A to C (initial series)}

The profile change is most pronounced in the 14 January 1992 (NW) and 2 November 1991 (SW) events. For the NW event, the alongshore transport values are similar to average annual alongshore transport results; alongshore transport is lower for the southern profiles offshore of the seawall and revetment. In other words, there is a reduction in transport moving from north to south, which results in deposition in the southern section, this being particularly evident at Lines R12 and R14 (see Figures 20f and 20g). In general, for the northwest and west storms, only 50 percent to 60 percent of the sediment eroded from the feeder beach area is transported beyond R23 (see Table 9 comparing results for Lines R12 and R23). Therefore, the deep water that has developed through downcutting offshore of the toe of the revetment in the southern section of the study area acts as a partial trap to sediment moving to the south.

For the southwest storms, this trend is reversed, with alongshore transport increasing in a northerly direction. This results in erosion between Lines R14 and R11, which primarily affects the ephemeral beach deposit that is located south of the Waterworks revetment. The fact that the Waterworks revetment acts as a partial littoral barrier (i.e., a short groin) is not captured by the 


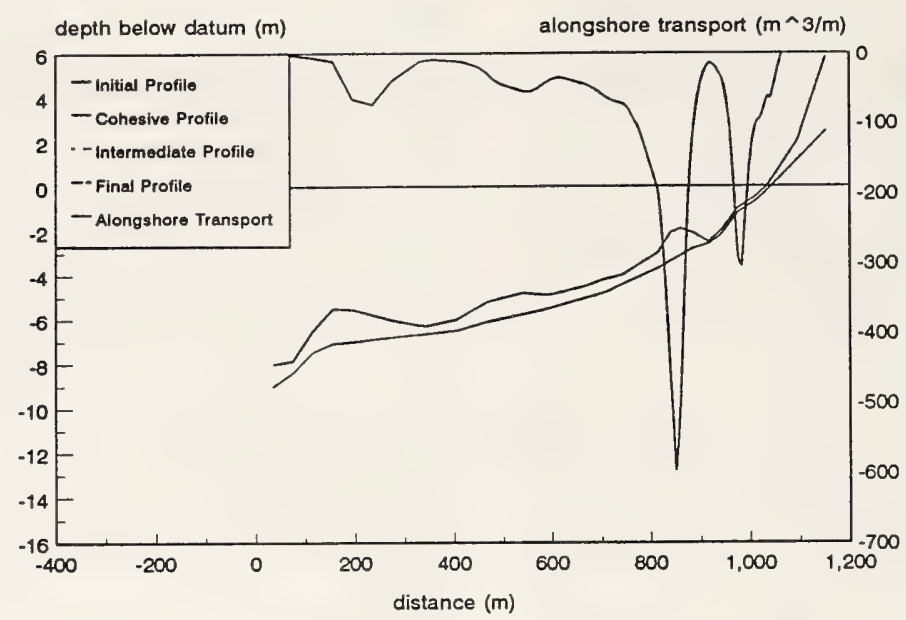

Total Transport $-76,181 \mathrm{~m}^{\wedge} 3$

a. Profile R8 3-D modeling for the 14 January, 1992 storm, $d_{50}=0.2 \mathrm{~mm}$ actual $W$. $L$.

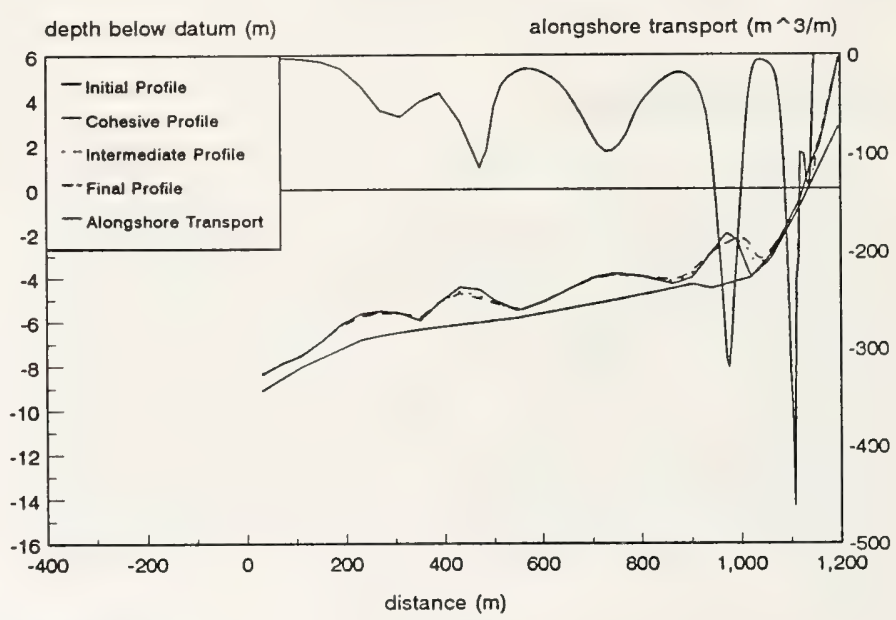

Total Transport $-65,821 \mathrm{~m}^{\wedge} 3$

b. Profile R9 3-D modeling for the 14 January, $1992 \mathrm{storm}, d_{50}=0.2 \mathrm{~mm}$ actual W.L.

Figure 20. Profile change results from Run B (Sheet 1 of 6 ) 


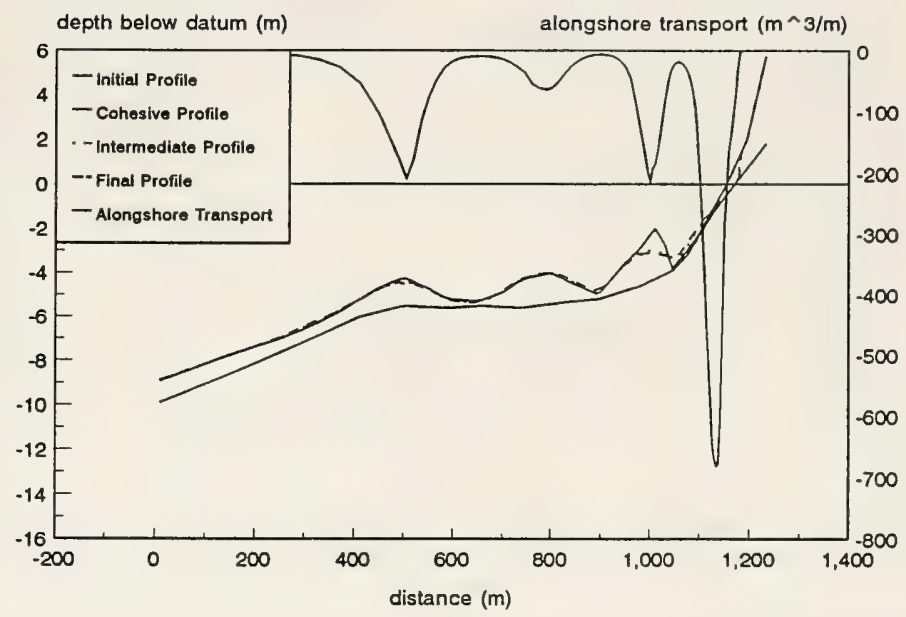

Total Transport $-76,438 m \wedge 3$

c. Profile R9a 3-D modeling for the 14 January, 1992 storm, $d_{50}=0.2 \mathrm{~mm}$ actual W.L.

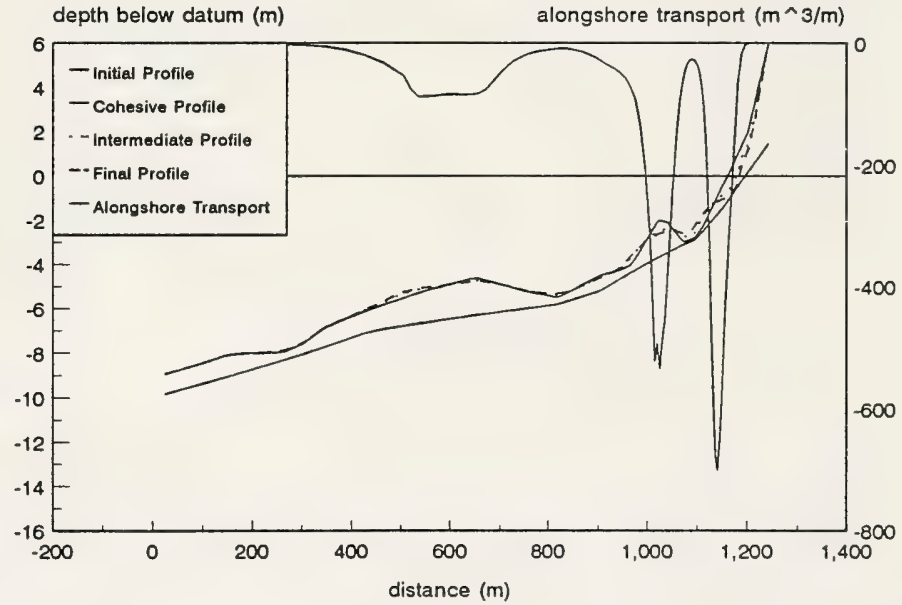

Total Transport $-84,673 \mathrm{~m}^{\wedge} 3$

d. Profile R10 3-D modeling for the 14 January, 1992 storm, $d_{50}=0.2 \mathrm{~mm}$ actual W.L.

Figure 20. (Sheet 2 of 6 ) 


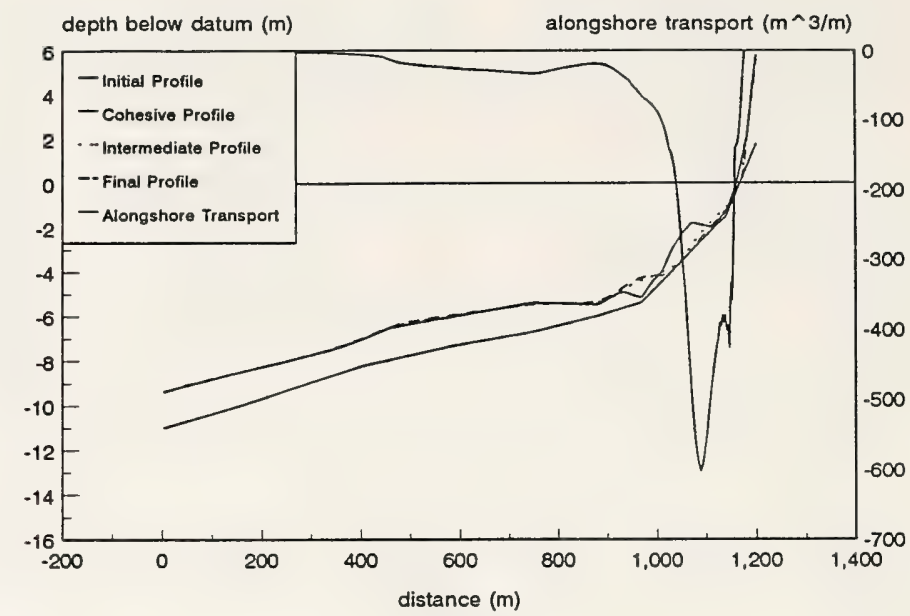

Total Transport $-76,167 \mathrm{~m}^{\wedge} 3$

e. Profile R11 3-D modeling for the 14 January, 1992 storm, $d_{50}=0.2 \mathrm{~mm}$ actual W.L.

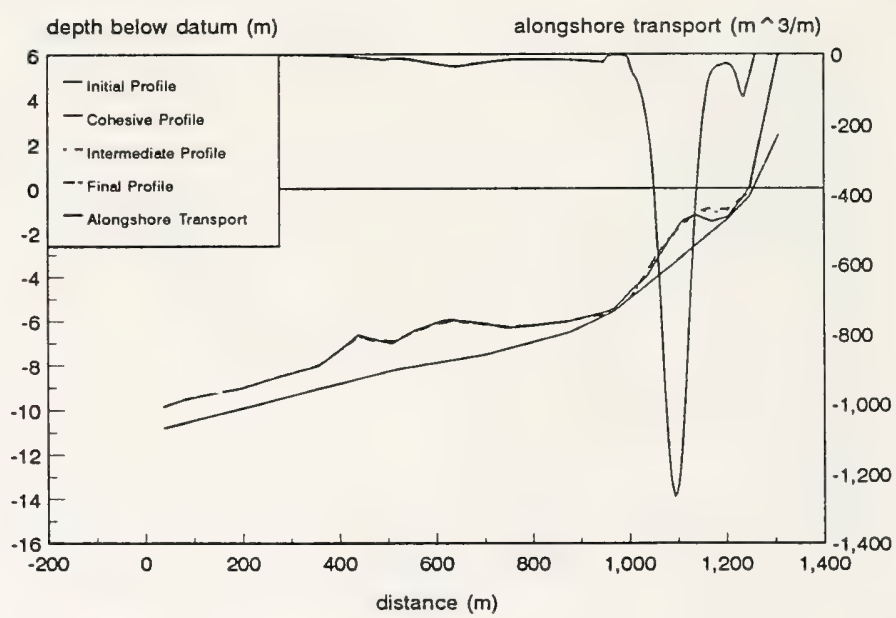

Total Transport $-108,416 \mathrm{~m}^{\wedge} 3$

f. Profile R12 3-D modeling for the 14 January, 1992 storm, $d_{50} 3=0.2 \mathrm{~mm}$ actual W.L.

Figure 20. (Sheet 3 of 6 ) 


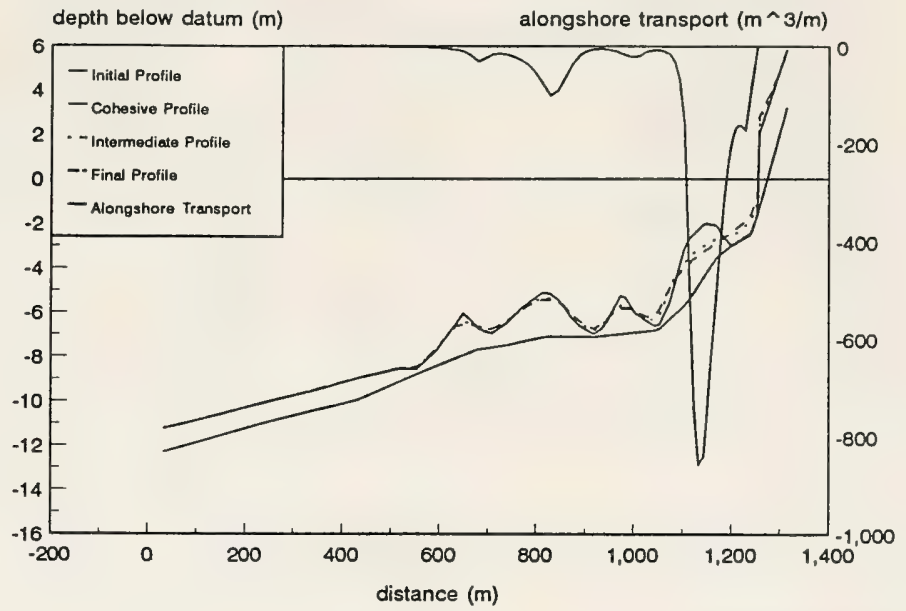

Total Transport $-74,825 \mathrm{~m}^{\wedge} 3$

g. Profile R14 3-D modeling for the 14 January, 1992 storm, $d_{50}=0.2 \mathrm{~mm}$ actual W.L.

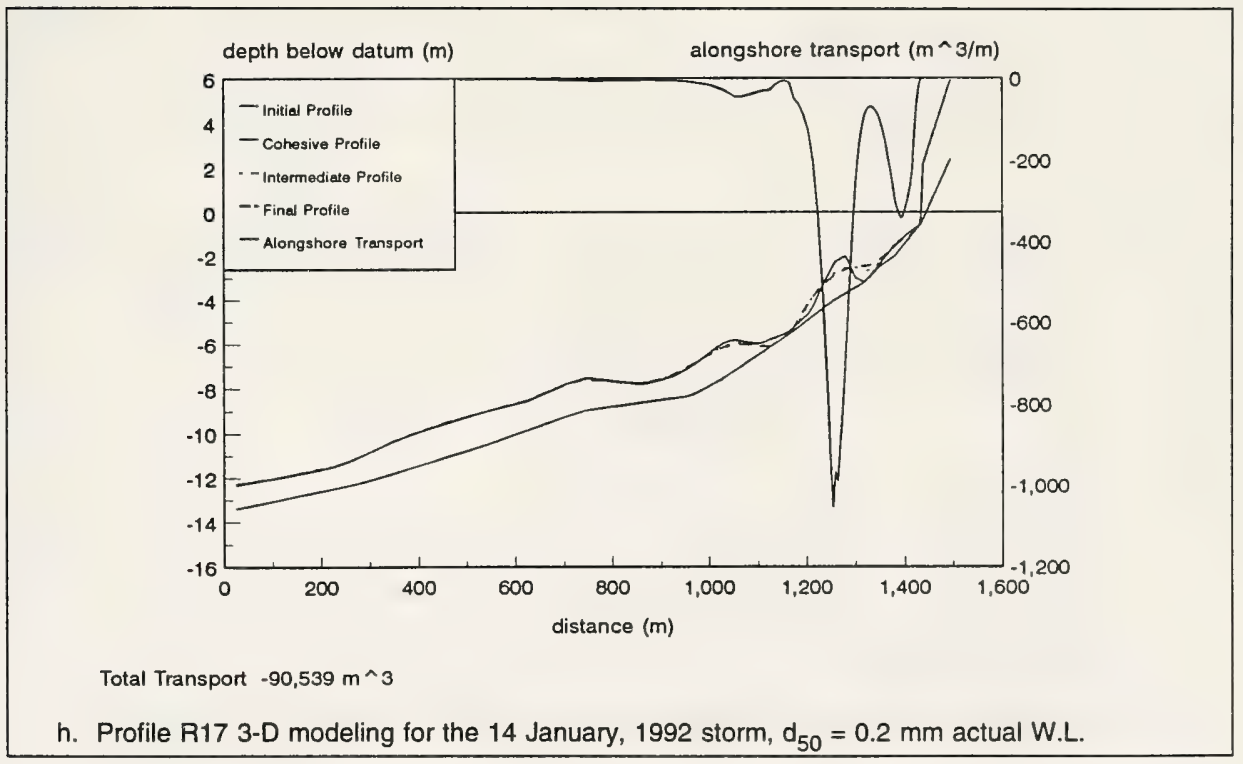

Figure 20. (Sheet 4 of 6 ) 


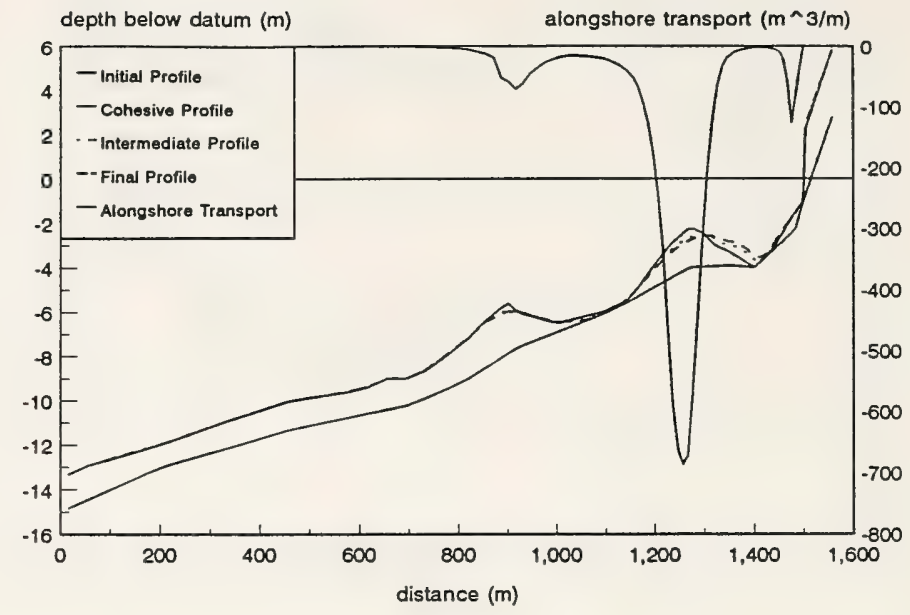

Total Transport $-73,101 \mathrm{~m}^{\wedge} 3$

i. Profile R20 3-D modeling for the 14 January, 1992 storm, $d_{50}=0.2 \mathrm{~mm}$ actual W.L.

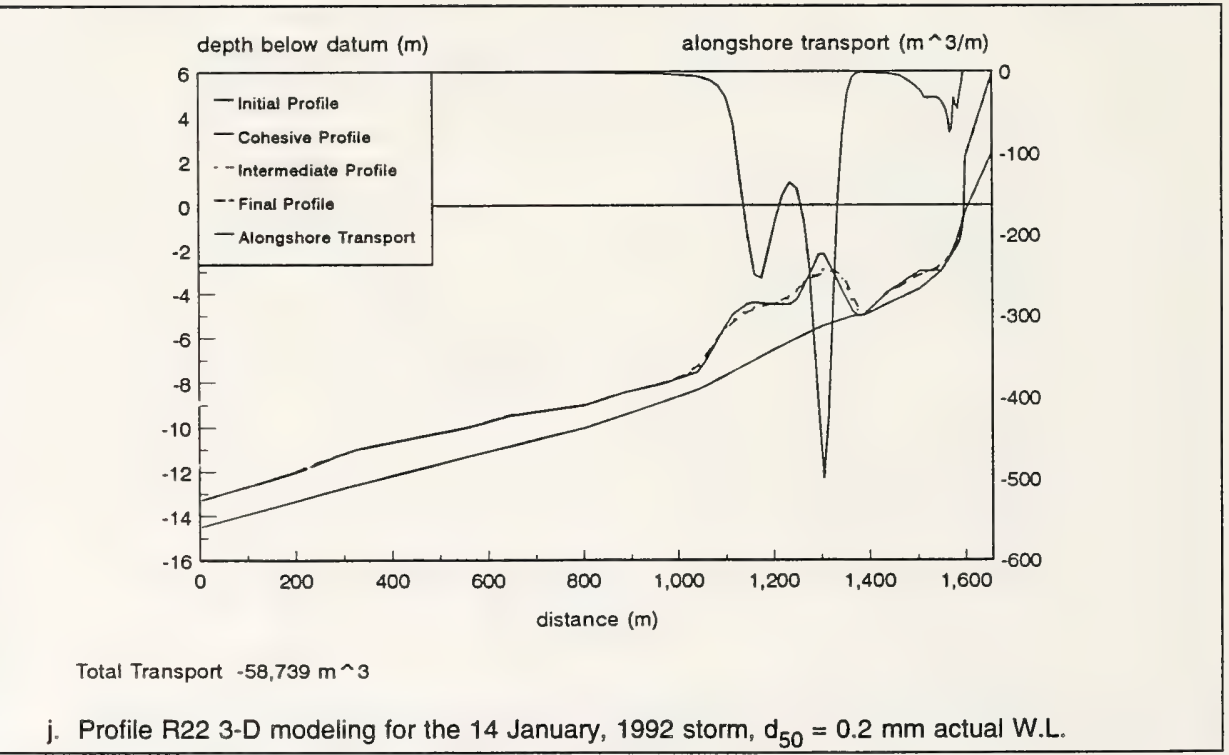

Figure 20. (Sheet 5 of 6 ) 


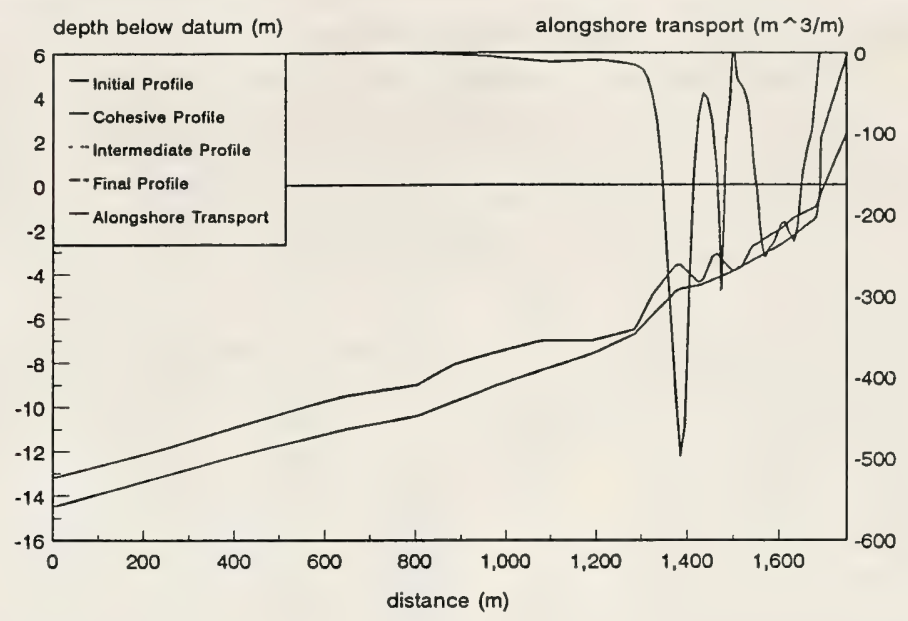

Total Transport $\cdot 68,254 m \wedge 3$

k. Profile R23 3-D modeling for the 14 January, 1993 storm, $d_{50}=0.2 \mathrm{~mm}$ actual W.L.

Figure 20. (Sheet 6 of 6 )

3-D model results. Sand eroded from the beach south of the Waterworks revetment (and from the south end of the feeder beach) is deposited at the fillet beach.

The predicted change for the 24 January 1992 event is not that much different from the changes predicted under the 2-D modeling, which is a result of the relatively low net alongshore transport values associated with this storm, which swings from southwest to northwest. However, erosion in the southern section of the feeder beach is predicted with increasing southerly transport in this area (from Line R10 to R11). This erosion is balanced by some minor deposition in the vicinity of Lines R12 to R14.

The increased "volatility" of the sand cover that occurred in the NW and SW storms results in both more and less exposure of glacial till compared to the 2-D cross-shore results of the section titled "Results of Cross-shore Modeling with Multiple Grain Sizes" (i.e., where only the inner surf zone featured significant changes to profile shape). With the 3-D results, larger areas of till were exposed where a section of the profile was subject to erosion due to increasing alongshore transport, whereas depositional conditions occurred in other areas, burying till that was previously exposed in troughs between bars. 


\section{Table 9 \\ 3-D COSMOS Modeling, St. Joseph Harbor, Michigan ${ }^{1}$}

\begin{tabular}{|c|c|c|c|c|c|c|c|c|c|}
\hline \multirow[b]{2}{*}{ Profile } & \multicolumn{3}{|c|}{$\begin{array}{c}\text { Actual Water Level } \\
d_{50}=0.2 \mathrm{~mm} \\
\text { Marker Depth }=-2.5 \mathrm{~m}\end{array}$} & \multicolumn{2}{|c|}{$\begin{array}{c}\text { Actual Water Level } \\
d_{50}=2.0 \mathrm{~mm} \\
\text { Marker Depth }=-2.5 \mathrm{~m}\end{array}$} & \multicolumn{2}{|c|}{$\begin{array}{c}\text { High Water Level } \\
d_{50}=0.2 \mathrm{~mm} \\
\text { Marker Depth }=-2.5 \mathrm{~m}\end{array}$} & \multicolumn{2}{|c|}{$\begin{array}{c}\text { Actual Water Level } \\
d_{50}=2.0 \mathrm{~mm} \\
\text { Marker Depth }=-0.5 \mathrm{~m}\end{array}$} \\
\hline & $\begin{array}{l}\text { Pre-fill A } \\
\text { 2-Nov-91 }\end{array}$ & $\begin{array}{l}\text { Pre-fill B } \\
\text { 14-Jan-92 }\end{array}$ & $\begin{array}{l}\text { Pre-fill C } \\
\text { 24-Jan-92 }\end{array}$ & $\begin{array}{l}\text { Pre-fill G } \\
\text { 2-Nov-91 }\end{array}$ & $\begin{array}{l}\text { Pre-fill H } \\
\text { 14-Jan-92 }\end{array}$ & $\begin{array}{l}\text { Pre-fill I } \\
\text { 2-Nov-91 }\end{array}$ & $\begin{array}{l}\text { Pre-fill J } \\
\text { 14-Jan-92 }\end{array}$ & $\begin{array}{l}\text { Pre-fill K } \\
\text { 14-Jan-92 }\end{array}$ & $\begin{array}{l}\text { Post-fill L } \\
\text { 14-Jan-92 }\end{array}$ \\
\hline 8 & 16,236 & $-76,181$ & $-42,246$ & 2,556 & $-15,694$ & 22,307 & $-83,340$ & $-14,264$ & $-13,463$ \\
\hline 9 & 14,334 & $-65,821$ & $-33,298$ & 12,549 & $-16,434$ & 25,198 & $-71,653$ & $-17,204$ & $-17,076$ \\
\hline $9 a$ & 34,721 & $-76,438$ & $-17,188$ & 5,959 & $-16,265$ & 51,798 & $-103,042$ & $-16,241$ & $-17,712$ \\
\hline 10 & 36,180 & $-84,673$ & $-19,024$ & 5,930 & $-17,549$ & 44,014 & $-99,501$ & $-14,849$ & $-15,446$ \\
\hline 11 & 44,404 & $-76,167$ & $-15,055$ & 6,360 & $-15,398$ & 44,273 & $-93,430$ & $-18,122$ & $-19,778$ \\
\hline 12 & 29,832 & $-108,416$ & $-37,910$ & 4,638 & $-19,803$ & 32,404 & $-117,843$ & $-17,659$ & $-18,086$ \\
\hline 14 & 21,790 & $-74,825$ & $-27,581$ & 3,450 & $-14,978$ & 13,913 & $-61,701$ & $-14,547$ & $-14,551$ \\
\hline 17 & 30,018 & $-90,539$ & $-27,761$ & 4,870 & $-17,416$ & 25,109 & $-87,122$ & $-17,262$ & $-17,262$ \\
\hline 20 & 23,346 & $-73,101$ & $-22,640$ & 3,681 & $-13,837$ & 14,834 & $-64,358$ & $-12,934$ & $-12,934$ \\
\hline 22 & 21,354 & $-58,739$ & $-13,839$ & 3,584 & $-11,519$ & 11,957 & $-50,652$ & $-12,177$ & $-12,177$ \\
\hline 23 & 30,297 & $-68,254$ & $-16,223$ & 4,679 & $-13,076$ & 27,475 & $-67,874$ & $-14,005$ & $-14,005$ \\
\hline
\end{tabular}

\section{Runs D to F (post beachfill series)}

The three initial runs were repeated with Lines R9 to R11 augmented with $50 \mathrm{~m}^{3} / \mathrm{m}$ of fine sand $(0.2 \mathrm{~mm})$ beach nourishment. This represents a low to average level of beach nourishment with a total volume of about $50,000 \mathrm{~m}^{3}$ extending from about $2.4 \mathrm{~m}$ above datum to $1.2 \mathrm{~m}$ below datum. The results generally featured very little change in the predicted alongshore transport rates compared to the initial prefill series. It may be recalled that the orientation of the nearshore contours in the numerical model are established based on the 2.5-m contour (i.e., the "marker depth"). Therefore, since the beach nourishment only extends down to a depth of $1.2 \mathrm{~m}$, in the numerical model experiments, the beach nourishment does not have an influence on the rate of alongshore transport related to the orientation of the contours. Nevertheless, for the NW waves of the 14 January storm, slightly greater deposition is predicted at Lines R12 and R14 than in the initial series. Cross-shore transport processes result in rapid profile adjustment with erosion of the upper beach and deposition offshore for each of the storm events. For storms with NW waves, the erosion of the feeder beach does not appear to result in the rapid movement of a defined pulse or slug of sediment. 


\section{Runs $\mathrm{G}$ and $\mathrm{H}$ (2 mm, coarse sediment)}

The 3-D version of COSMOS used here requires a single representative grain size. The first two series of runs $(A-F)$ were completed with a grain size of $0.2 \mathrm{~mm}$. The SW and NW storm events were then repeated with $2-\mathrm{mm}$ sediment. This coarser grain size is representative of the coarse beachfill derived from upland sources. However, the coarse fraction is generally found only close to shore (see Parson and Smith (1995)) and therefore, the results of these runs are probably only valid for the inner surf zone and upper beach areas.

The reduction in predicted alongshore transport (compared to the fine grain size) was not as dramatic in these runs as it was for the average annual alongshore transport results (see Table 9). In general, the profiles are more stable, as expected. Therefore, areas of exposed till remain exposed, while sections of buried till are not uncovered.

\section{Runs I and J (high water level)}

In this series of runs, the 3-D change for the SW and NW storms is predicted under high lake level conditions (the grain size of $0.2 \mathrm{~mm}$ represented pre-fill conditions). For the SW storm event, the predicted alongshore transport is lower for the southern section from Line R14 to R23 than that predicted with the average lake level conditions (see Table 9). The alongshore transport is reduced by 10 to 50 percent owing to the greater water depths offshore of the revetment. In contrast, the alongshore transport rates for the northern section of the study area shoreline (including the feeder beach and the fillet beach) are increased by about 40 percent as larger waves can reach steep sections of the upper beach under the high lake level conditions. For the SW storm, these changes to the alongshore transport result in greater erosion south of the Waterworks revetment (i.e., Line R12) and at the north end of the feeder beach (R11), which is balanced by greater deposition along the north feeder beach and fillet beach.

These trends are reversed for the NW storm results, with increased southward-directed transport in the northern section and slightly decreased southerly transport in the southern section of the study area. As a result, predicted deposition is slightly greater at Lines R12 and R20.

\section{Runs K and L (pre- and post-fill with 0.5-m marker depth)}

As noted earlier, placement of the beachfill did not change the contours which the incident waves encounter for 3-D Runs D to F. This was a result of the fact that the "marker depth" which delineates the main pathway for alongshore transport was specified as the $2.5-\mathrm{m}$ depth contour, which is located well offshore of the toe of the beachfill. Therefore, Runs $\mathrm{K}$ and $\mathrm{L}$ were performed with a marker depth of only $0.5 \mathrm{~m}$, which better represented the contour changes created by the beachfill. Evaluations of pre- and post-beachfill 
conditions were performed with a grain size of $2 \mathrm{~mm}$. The coarse grain size was selected because the $0.5-\mathrm{m}$ marker depth represents conditions where most of the sediment is moving relatively close to shore.

Review of the modeling results (summarized in Table 9) shows that slight increases in alongshore sediment transport are predicted in the beachfill area for the post-fill Run L (Lines R9a to R11) compared to the pre-fill Run K. However, most of the profile change in the beachfill area for Run L is related to profile adjustment. The gradients in potential alongshore transport are very low and do not result in rapid redistribution of the feeder beach sediment to the south.

Results of Runs $\mathrm{H}$ and $\mathrm{K}$, which differ only in the assigned marker depth ( $2.5 \mathrm{~m}$ versus $0.5 \mathrm{~m}$, respectively) are very similar, with only minor deviations in the beachfill area (see Table 9).

\section{Assessment of predicted glacial till downcutting}

For each of the 3-D model runs, downcutting of the exposed areas of glacial till was determined based on the magnitude of shear stress and the rate of wave energy dissipation at the location of the exposures, over the duration that the till was exposed. The approach used to calculate downcutting is described in Parson, Morang, and Nairn (1996).

Downcutting results for the 2 November 1991 (SW) storm are compared in Figures $21 \mathrm{a}$ to $21 \mathrm{k}$, showing the difference in predicted downcutting between the $0.2-\mathrm{mm}$ and $2-\mathrm{mm}$ results (i.e., Run A versus G). In general, the predicted downcutting (or vertical erosion) of the exposed till areas is predicted to be in the range of 0 to $0.15 \mathrm{~m}$. The occurrences and magnitude of downcutting are greater for the $0.2-\mathrm{mm}$ sediment for the northern section of the shoreline (i.e., where a beach exists with till underneath). For the southern profiles offshore of the revetment, the magnitude and occurrence of downcutting are similar. This finding relates to the fact that changes to the sand cover were much more limited for the lake bed offshore of the revetment for both fine- and coarsegrain sediment. Modeling was also performed for the 14 January 1992 storm, and the results were similar to the 2 November 1991 results.

The downcutting predicted for these storm events corresponds to storm conditions that might be expected once every 1 to 5 years. The bathymetry comparisons have identified annual lake bed lowering in the range of 0.06 to $0.10 \mathrm{~m} /$ year for the revetment shoreline between 1945/6 and 1964/5. Although lowering rates decreased between 1964/5 and 1991, lowering in the range of 0.09 to $0.13 \mathrm{~m} /$ year occurred between 1991 and 1995 . The numerical model results of this investigation imply that significant downcutting is still ongoing, not only in the vicinity of Profiles R9 to R12, but also for the deeper profiles offshore of the revetment between Lines R12 and R23. 


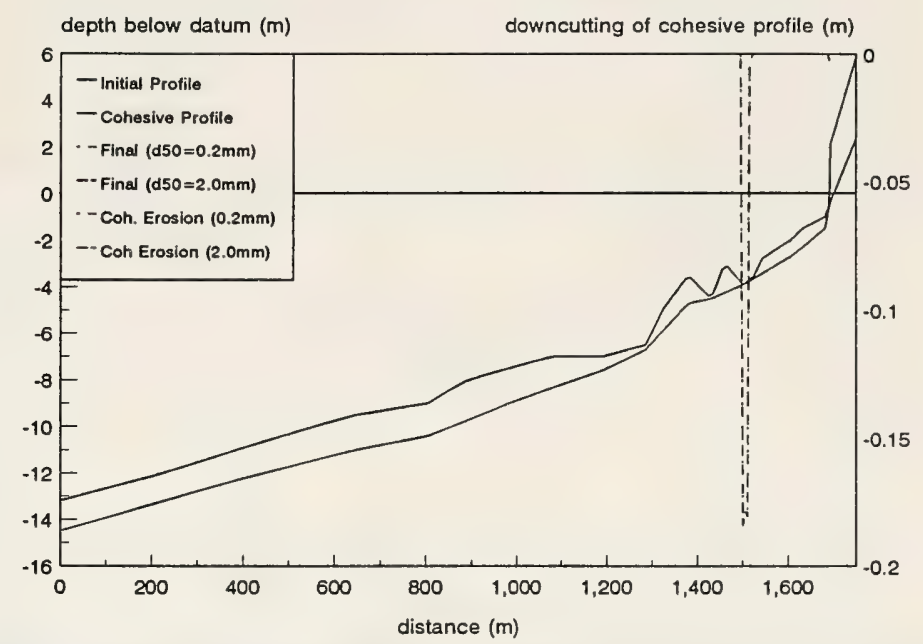

a. Profile R23 cohesive profile erosion during 2 November, 1991 storm, $d_{50}=0.2 \mathrm{~mm} \& 2.0 \mathrm{~mm}$ actual W.L.

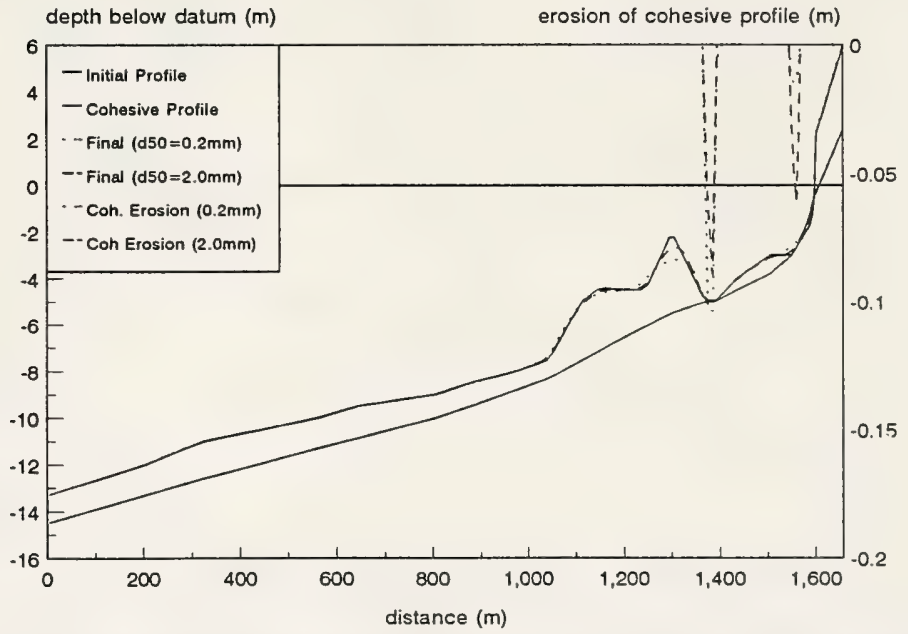

b. Profile R22 cohesive profile erosion during 2 November, 1991 storm, $\mathrm{d}_{50}=0.2 \mathrm{~mm} \& 2.0 \mathrm{~mm}$ actual W.L.

Figure 21. Downcutting results for the 2 November 1991 (SW) storm, Runs A and G (Sheet 1 of 6) 


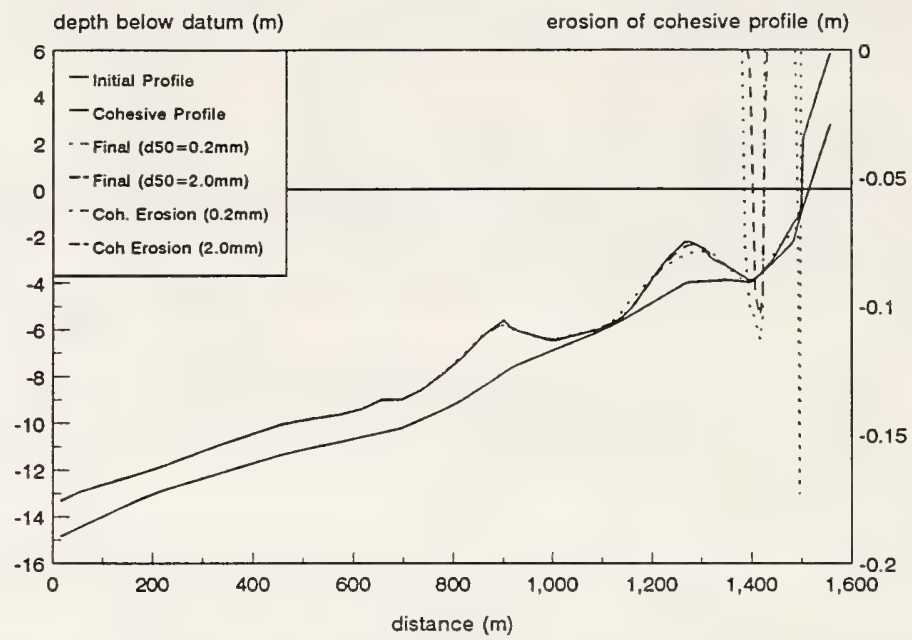

c. Profile R20 cohesive profile erosion during 2 November, $1991 \mathrm{storm}, \mathrm{d}_{50}=0.2 \mathrm{~mm} \& 2.0 \mathrm{~mm}$ actual W.L.

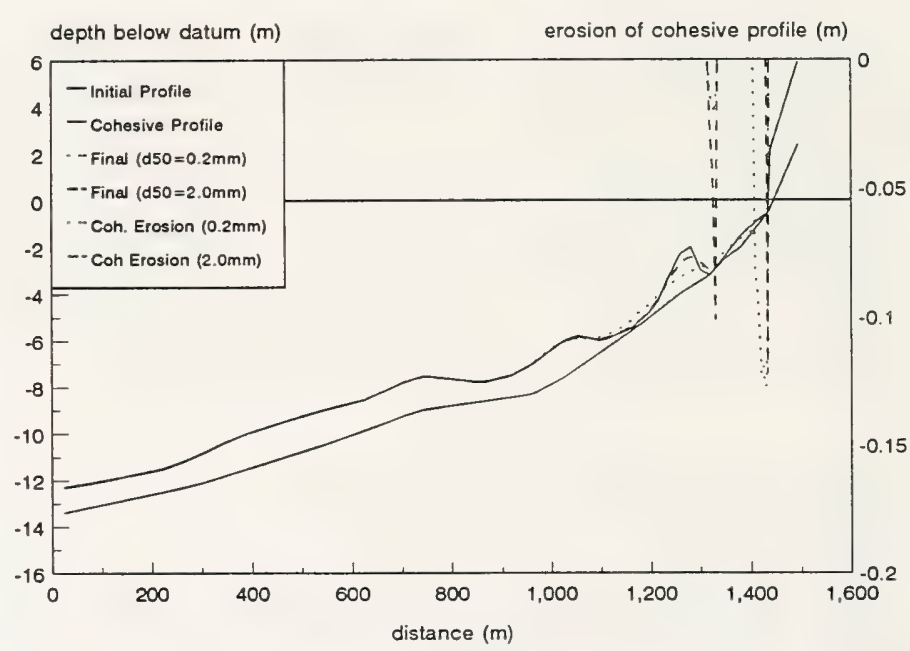

d. Profile R17 cohesive profile erosion during 2 November, $1991 \mathrm{storm}, \mathrm{d}_{50}=0.2 \mathrm{~mm} \& 2.0 \mathrm{~mm}$ actual W.L.

Figure 21. (Sheet 2 of 6 ) 

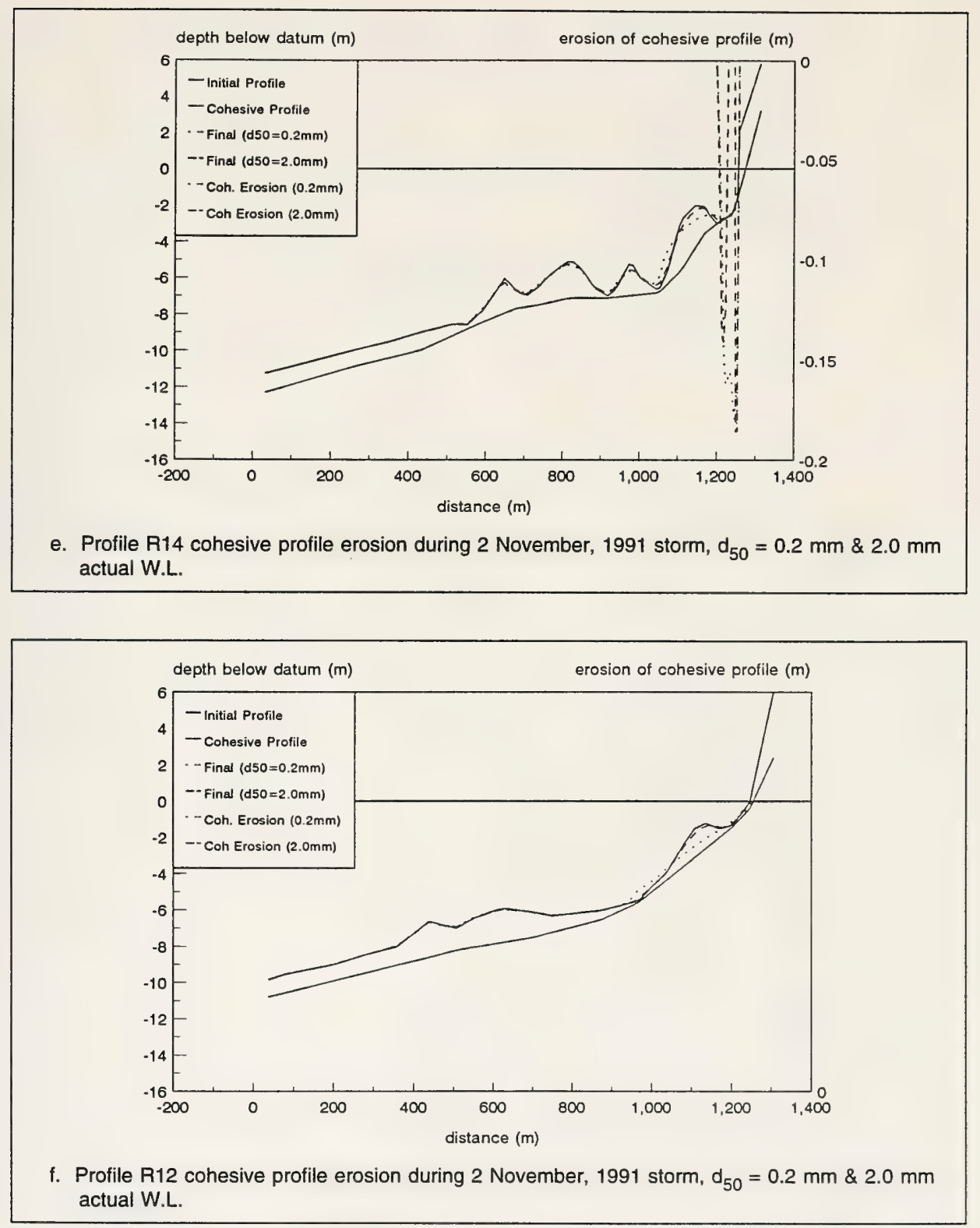

Figure 21. (Sheet 3 of 6 ) 

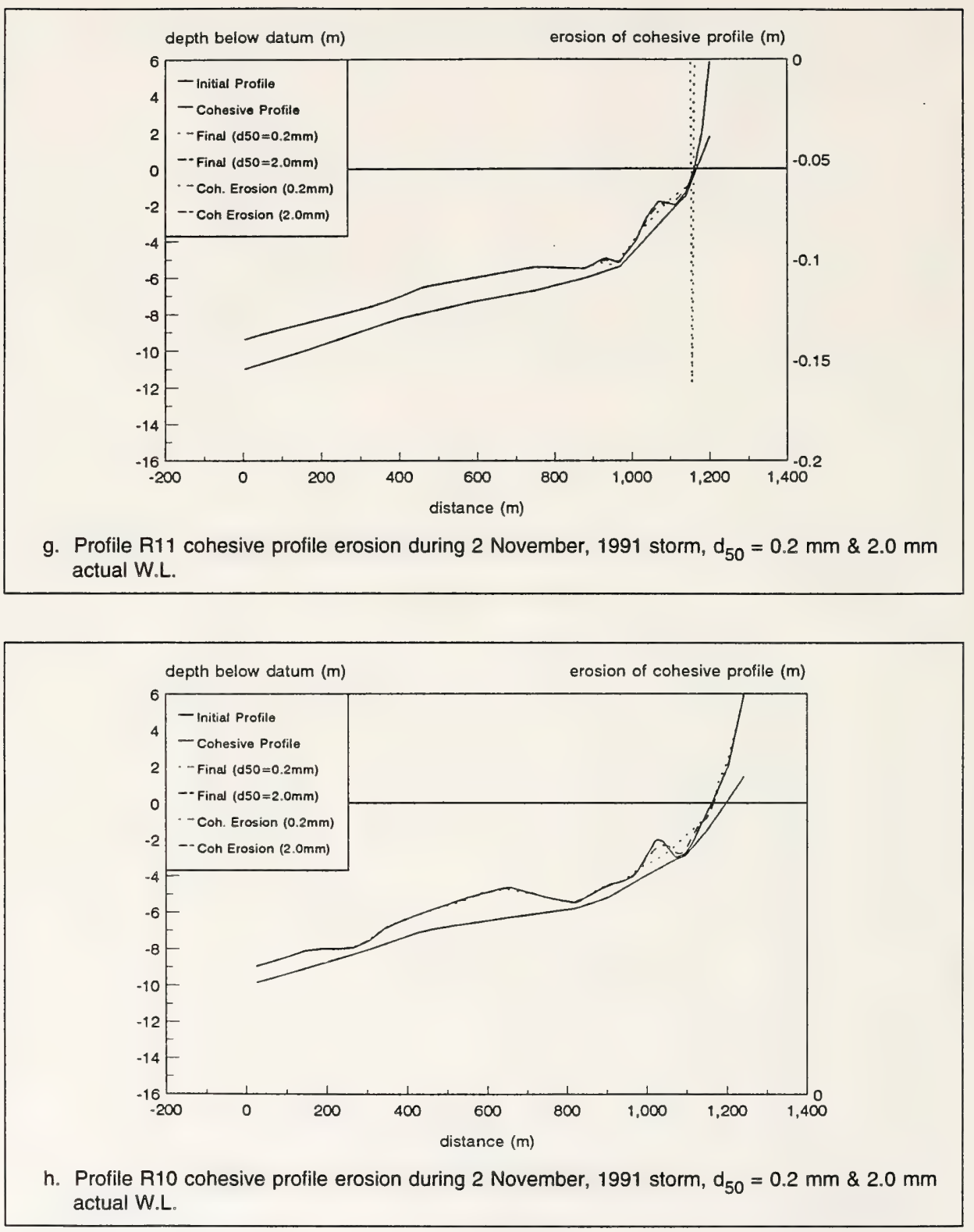

Figure 21. (Sheet 4 of 6 ) 

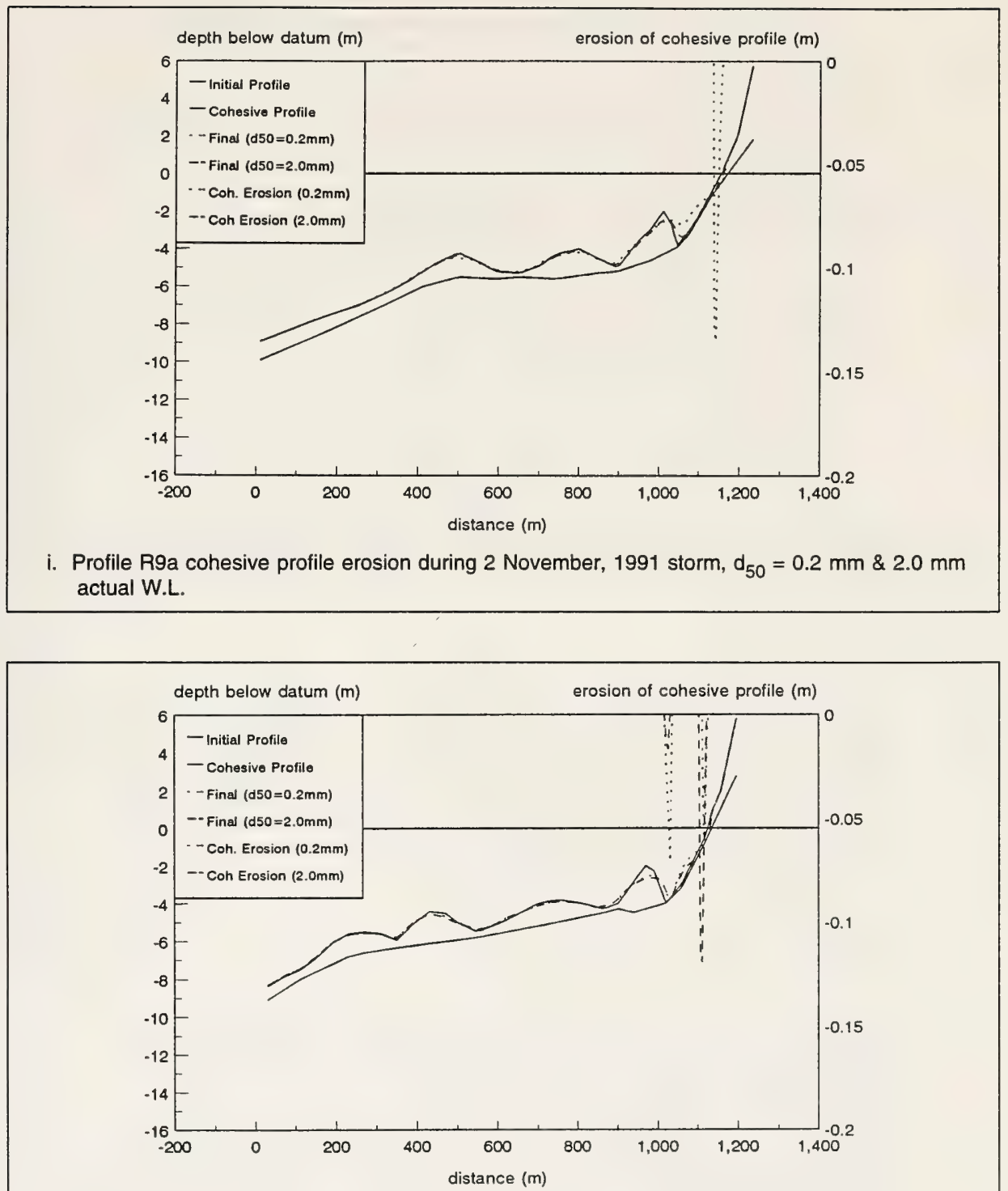

j. Profile R9 cohesive profile erosion during 2 November, 1991 storm, $d_{50}=0.2 \mathrm{~mm} \& 2.0 \mathrm{~mm}$ actual W.L.

Figure 21. (Sheet 5 of 6 ) 


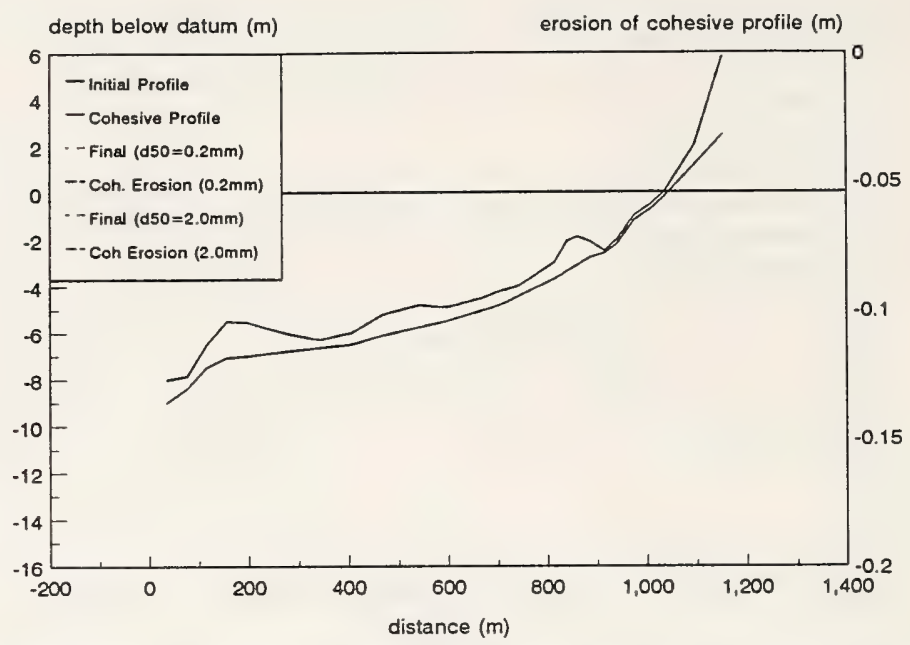

k. Profile R8 cohesive profile erosion during 2 November, 1991 storm, $d_{50}=0.2 \mathrm{~mm} \& 2.0 \mathrm{~mm}$ actual W.L.

Figure 21. (Sheet 6 of 6 )

The findings also indicate that the $2-\mathrm{mm}$ grain size sediment is much more effective than the $0.2-\mathrm{mm}$ grain size sediment at mitigating downcutting for those sections of shore where a beach deposit protects an underlying till layer. For profiles which feature deep water at the toe of a shore protection structure (and no beach), the coarse grain size sediment is no more effective than the fine grain size sediment in protecting the underlying glacial till from downcutting.

\section{Summary of the 3-D results}

A major limitation of the 3-D modeling was the limited number of profiles available to describe the bathymetry along the study area shore. The 3-D modelling was completed prior to the availability of detailed bathymetry from the 1995 SHOALS survey. The implication of this limitation was that the model results could only be interpreted in a general manner; detailed changes to the bathymetry were either not predicted or were not entirely reliable. Notwithstanding this limitation, several conclusions can be made based on the results of the $3-\mathrm{D}$ experiments.

The 3-D results confirmed that the deep water located offshore of the southern revetment-protected section of shore creates an impediment to alongshore transport. For northwest wave events, this results in some deposition in 
this area, including deposition at Line R12 which relates to the extension of the ephemeral beach south of the Waterworks revetment.

Southwesterly storms resulted in redistribution of sediment from the beach immediately south of the Waterworks revetment and from the south end of the feeder beach northwards to the fillet beach area.

The beachfill was predicted to respond very rapidly in the cross-shore direction, with the upper beach sediment being eroded and transported offshore as the profile readjusted to equilibrium form. However, the influence of alongshore transport had less immediate effects on the redistribution of sediment outside the feeder beach area. The sediment was predicted to move along the shore at a relatively slow rate, with deposition only perceptible at Lines R12 and R14 during the NW storm event. This result is in part related to the issue of actual versus potential alongshore transport rates for Lines R8 and R9. If the actual transport rates are less than the potential values predicted for Lines R8 and R9 during a northwest storm event, the volume of sediment transported to the feeder beach from the north will be much lower than the model predictions. A reduction in the rate of sediment transport from the north will accelerate erosion of the feeder beach and the associated alongshore transport of sediment may occur more rapidly than predicted during a northwest storm event.

The influence of alongshore transport on the movement of bars can result in significant changes to the exposure of glacial till over the duration of a single storm. Presumably, it is these changes which contribute to the ongoing downcutting of the underlying glacial till in the vicinity of thick bar deposits. The volatility of the sand cover is diminished along the southern section of shore, which features deeper water offshore of the toe of the revetment. Predicted downcutting rates are much lower in this area and only occur for isolated sections of lake bed. The 3-D runs with a 2-mm grain size support the 2-D findings: because of the stability of the sand cover, existing exposures of till remained exposed and buried sections remained protected. The influence of fluctuating lake levels on the exposure of the underlying glacial till has also been shown to be an important factor (see section titled "Bathymetry Comparisons and Sediment Budget Calculations").

\section{Trends in Profile Change}

In the past 50 years, several factors have influenced the volume of sand above the cohesive profile at St. Joseph, including: obstructions to alongshore sediment transport (harbor jetties), construction of shore protection structures, the Section 111 beach nourishment program, and annual variability in alongshore sediment transport. The quantity and stability of the sand cover above the glacial till has an important impact on the magnitude and location of cohesive downcutting. Long-term profile comparisons were made from the four snapshots of the lake bed bathymetry $(1945 / 6,1964 / 5,1991$, and 1995) and are discussed below. A review of the profile data collected from 1991 to 1995 
was completed by CERC for the shore south of the harbor jetties to assess short-term trends in the changing volume of sand and gravel above the cohesive profile.

\section{Long-term profile change}

Four locations were selected for the long-term comparison of beach profiles (see Figure 10).

At almost $3 \mathrm{~km}$ north of the St. Joseph harbor jetties, Line 1 is located outside the zone of influence of the harbor structures. From 1945 to 1965, there was severe lowering of the lake bed (see Figure 22). This lowering was probably the result of erosion of the underlying till. In contrast, the 1965 to 1995 comparison showed little or no lowering but does feature bar migration related to water level fluctuations and wave action.

Line 2 is located $1,350 \mathrm{~m}$ north of the harbor jetties, in a transition zone between shoreline influenced by the fillet beach and unaffected shoreline. Due to the low density of soundings in the 1945/6 survey, the bar features cannot be discerned. However, a depositional trend is evident from 1945 to 1995 , especially in the nearshore zone (see Figure 11). The water level at the time of the 1995 survey was approximately $1 \mathrm{~m}$ above the historic lows recorded in 1964/65. The 1995 nearshore sandbar is located approximately $100 \mathrm{~m}$ inshore of the 1964/5 nearshore bar (see Figure 11).

Line 3 is located in the middle of the large offshore depression in the lake bed that developed between 1945 and 1995. Severe erosion (vertical displacement) of the sand and cohesive substrate occurred between the 10-m depth contour and the shoreline (see Figure 12). The 5-m depth contour moved inshore by $450 \mathrm{~m}$ in 50 years, for an average annual contour recession rate of $9 \mathrm{~m} /$ year. With the construction of the revetment several decades ago, the shoreline position has been fixed at Line 3; however, the nearshore profile has continued to erode and the nearshore slopes have become progressively steeper from 1945 to 1995 .

Line 4 is located $8.2 \mathrm{~km}$ south of the jetties in a zone which, up until recently, may not have been significantly influenced by the harbor jetties. From 1945 to 1965 , profile lowering occurred from the shoreline out to the -7-m depth contour (see Figure 13). There appears to be some recovery of the nearshore profile from 1965 to 1991, which corresponds to the period when the Section 111 beach nourishment program was introduced updrift of Line 4. A second possible explanation for the apparent gain in nearshore sand levels is the onshore migration of bar features due to water level rise between 1964/65 and 1991 (refer to Parson et al. (1996)). From 1991 to 1995, the profile comparison revealed significant lowering of the nearshore profile over a 200-m-wide zone. 


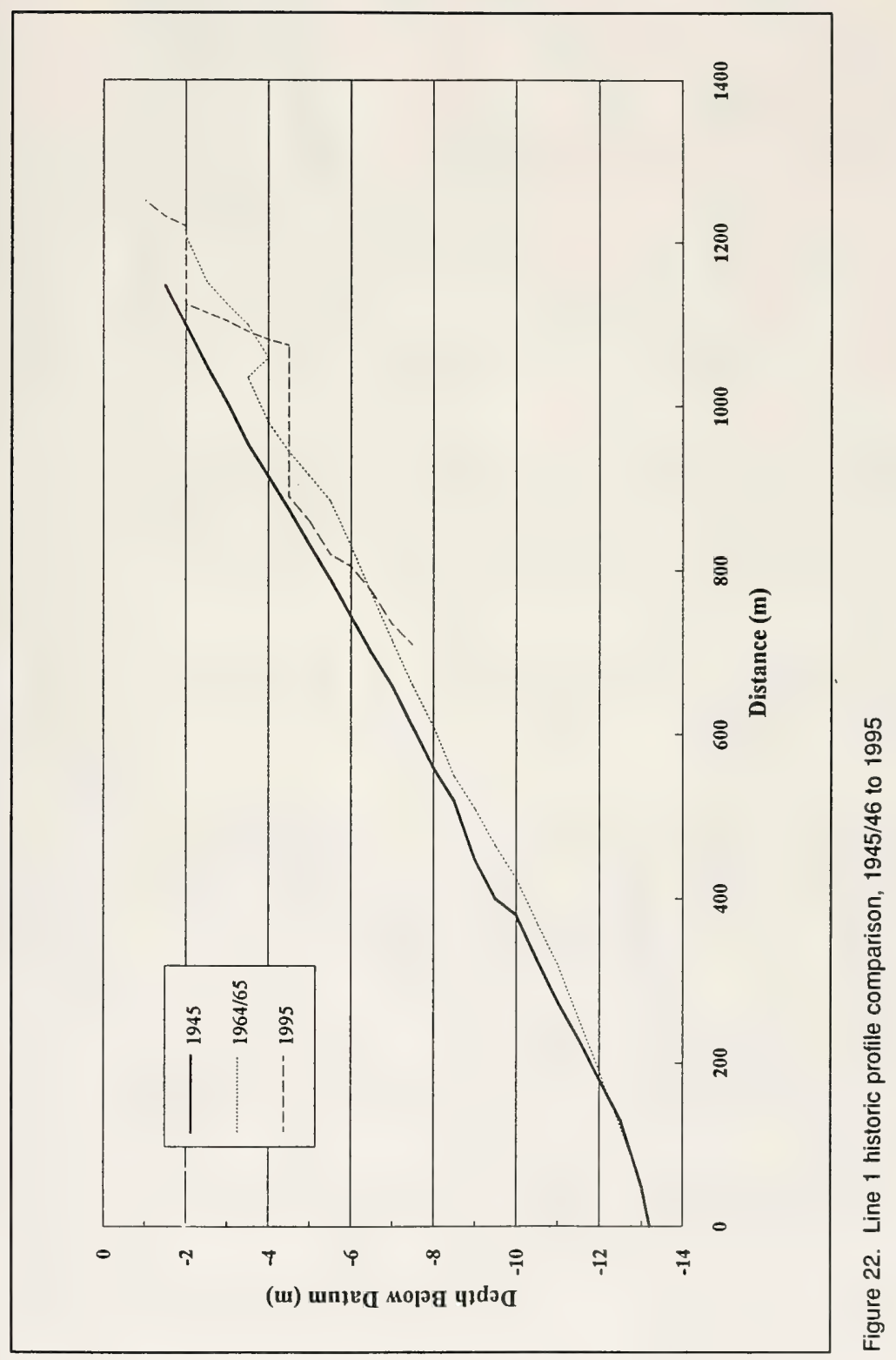




\section{Short-term profile change}

Changes in profile volumes were calculated by CHL for 14 stations monitored over a 4-year period from 1991 to 1995 (Figure 4). Three distinct zones for the volume calculations were selected: beach/nearshore bar, offshore bar, and offshore. The three zones identified distinct characteristics of the offshore zone south of St. Joseph. However, given the size of the study area and the diversity of the nearshore conditions, the locations of these zones could not be standardized by distance (shore-perpendicular) or depth. Consequently, their location on each profile was based on individual morphology. In all cases, the earliest profile was used as a baseline to compare changes in the volumes of sediment on the profile from 1991 to 1995 . Positive volumetric changes indicate the amount of sand on the profile has increased since the base year of the comparison. Negative volume changes occur when there is a reduction in sand cover and/or irreversible lowering of the cohesive profile. For the wide offshore zone in particular, it is noted that small errors in the profile surveys could result in large errors in estimated profile volume changes.

An overlay of the long (beach and offshore) profiles for R8 is presented in Figure 23. Line R8 is located in a transition zone between the south fillet beach and feeder beach. The bathymetry comparison showed that the lake bed north of R8 was stable or accretional. This area is in the lee of the harbor jetties and any sand transported into this zone is effectively trapped (i.e., because of sheltering from northerly wave attack).

The results of the profile volume calculations and the timing and volume of beach nourishment for Profile R8 are presented in Figure 23. The beach/ nearshore bar showed deposition from 1991 to 1995; however, the offshore bar continued to erode despite the beach nourishment.

Profile R10 (Figure 24) is located in the feeder beach zone. The volumetric results suggest that the beach nourishment has been successful in maintaining the profile volumes in all three zones: beach/nearshore bar, offshore bar, and offshore (see Figure 24). Over $100,000 \mathrm{~m}^{3}$ of sand was placed on the feeder beach in 1991, which initially added approximately $300 \mathrm{~m}^{3} / \mathrm{m}$ of sand to the R10 profile. In 1993, the volume of sand on the profile increased to $600 \mathrm{~m}^{3} / \mathrm{m}$ above the volumes recorded on August 14, 1991 (the base profile).

Profile R11 (Figure 25) is located at the southern end of the feeder beach and is in a transitional zone between depositional and erosional profiles. All three profile zones, especially the offshore bar, experienced an erosional trend from 1991 to 1995 (see Figure 25). One possible explanation is the influence of the nearshore beach slope, which increased from 1:85 at R8 (which was depositional in the beach/nearshore bar zone) to $1: 30$ at profile R11. The numerical modeling indicated significant quantities of sediment could be transported in a cross-shore direction during a severe storm, especially when the nearshore slopes are steep. 

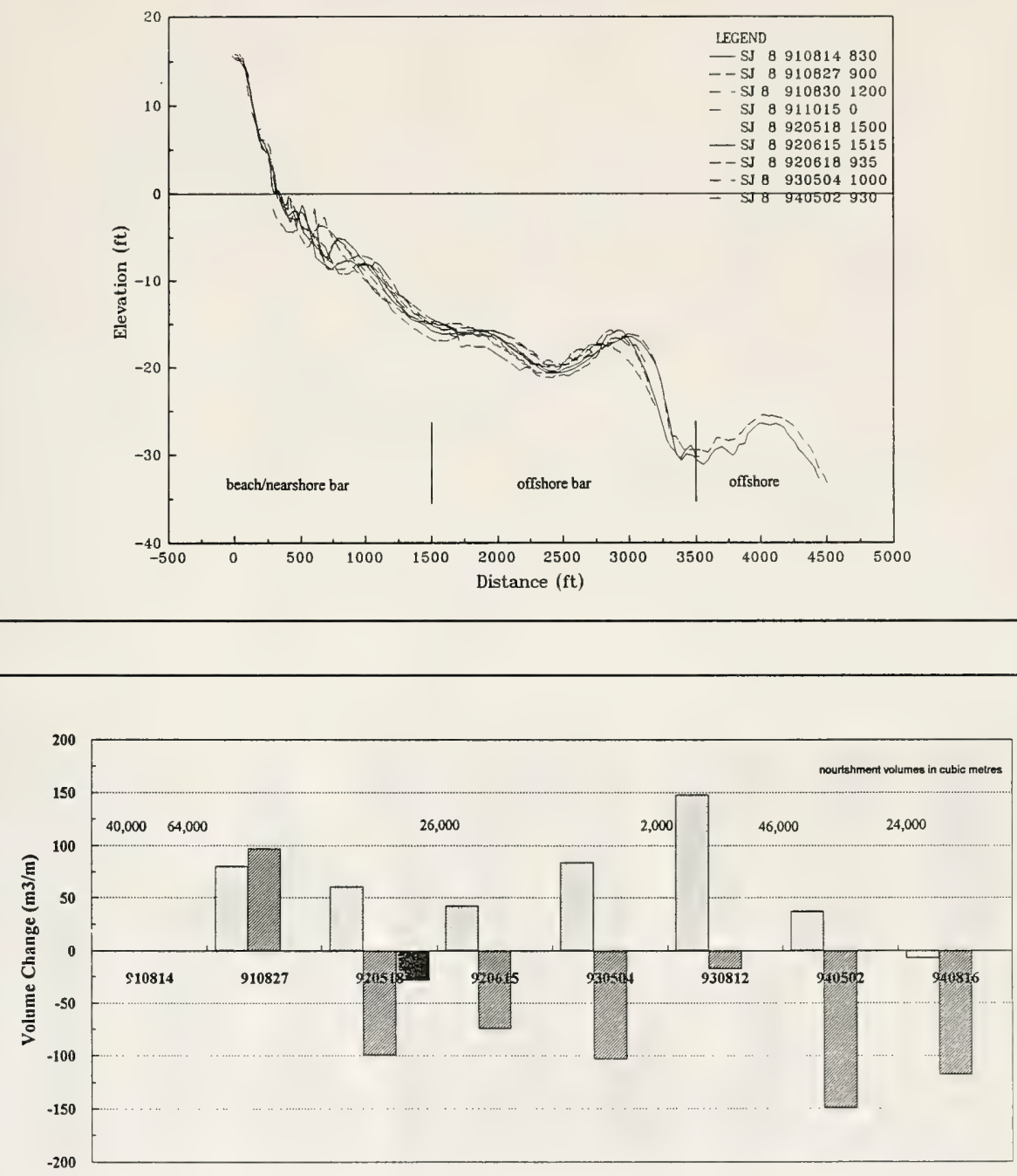

Date

$\square$ Beach and Nearshore Bar OfIshore Bar Oflshore

Figure 23. Profiles (beach and offshore) for R8 

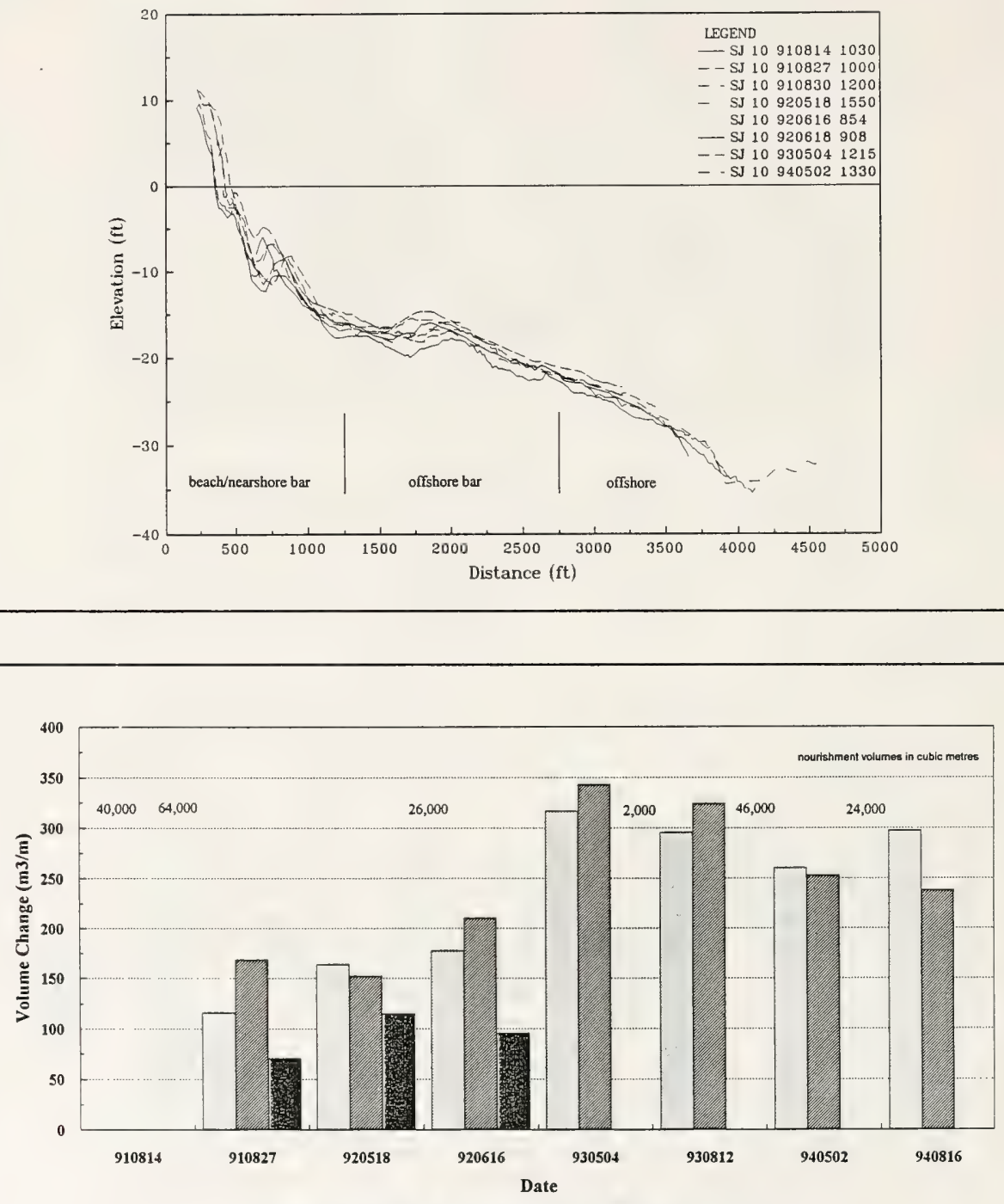

$\square$ Beach and Nearshore Bar Ofrshore Bar Orshore

Figure 24. Profiles (beach and offshore) for R10 

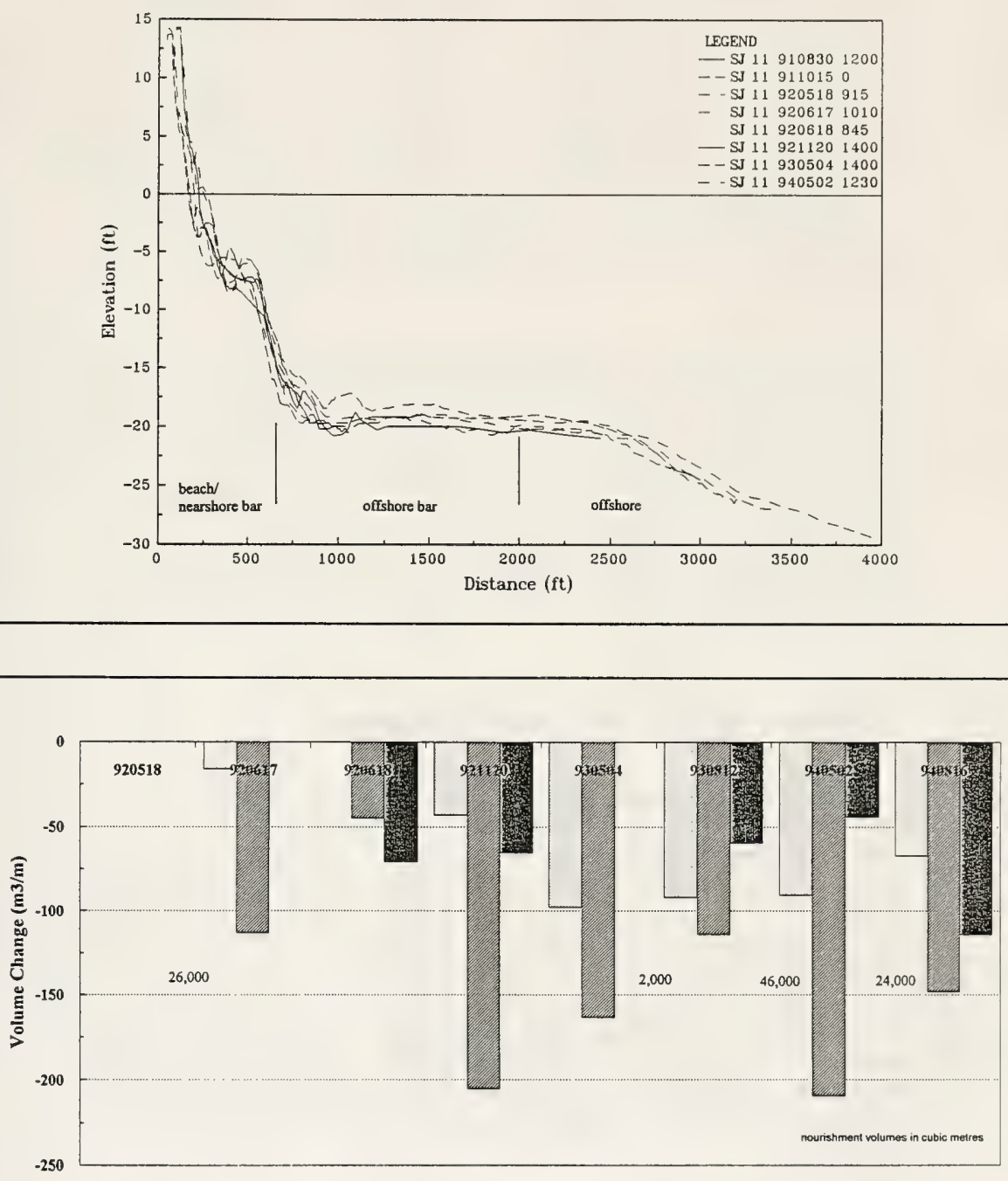

Date

$\square$ Beach and Nearshore Bar Offshore Bar ofshore

Figure 25. Profiles (beach and offshore) for R11 
During the 3-year period (1991 to 1994) of the comparison at R14 (Figure 26), the volume of the beach/nearshore bar increased by $160 \mathrm{~m}^{3} / \mathrm{m}$, while the offshore bar volume increased by $500 \mathrm{~m}^{3} / \mathrm{m}$. The bathymetry comparisons revealed that R14 is located in the zone of most severe lake bed erosion, exceeding $4 \mathrm{~m}$ from 1945 to 1995 . However, during the period of the profile volume comparison, R14 may have been a depositional sink for sediment from the feeder beach (see Figure 26). If the annual rate of accumulation (approximately $200 \mathrm{~m}^{3} / \mathrm{m}$ ) at R14 had occurred over a $200-\mathrm{m}$ section of the shore, the depression in the lake bed near R14 could trap $40,000 \mathrm{~m}^{3}$ of sand per year moving in an alongshore direction, which is approximately equivalent to the annual volume of beach nourishment from 1991 to 1995.

Profile R22, located $5 \mathrm{~km}$ south of the harbor jetties, also appears to be directly influenced by the nourishment on the feeder beach (Figure 27). In the fall of 1992 , after $130,000 \mathrm{~m}^{3}$ of beach nourishment was placed on the feeder beach in 1991 and early 1992, the beach/nearshore bar and offshore bar gained significant quantities of sand, $375 \mathrm{~m}^{3} / \mathrm{m}$ and $220 \mathrm{~m}^{3} / \mathrm{m}$, respectively (see Figure 27). From the fall of 1993 to the fall of 1994, the trend reversed and the beach/nearshore bar and offshore bar eroded below the base volume of August 30,1991. This erosion trend may be explained by a break in the nourishment program from the spring of 1992 to the fall of 1993, decreasing the rate of sediment available for alongshore transport to the beaches south of the harbor jetties.

\section{Exposure of the Cohesive Substrate}

Exposure and downcutting of the cohesive profile underneath the sand or gravel lag at St. Joseph are the fundamental processes that determine at what rate the shoreline retreats over time. Several factors can lead to the exposure, or increase the potential for exposure, of the cohesive profile: (a) water level fluctuations and associated bar migration in response to wave action, (b) reduction in the overlying sand/gravel cover, (c) increase in nearshore beach slopes, and (d) changes in sediment grain size. The latter three factors have been investigated in the previous sections of Chapter 4, and in general, they have failed to fully explain the relatively even distribution of nearshore downcutting evident from the bathymetry and profile comparisons. This even distribution requires that the underlying till is exposed at all locations at some time. Variations in bar position with changing water levels appear to provide the missing explanation.

Monthly and yearly fluctuations in mean water levels for Lake Michigan are described in Figure 28. During the period of the investigation, 1945 to 1995, there was extreme variability in lake levels, with a low yearly mean of $0.3 \mathrm{~m}$ below chart datum (IGLD '85) recorded in 1964 and the high of $1.3 \mathrm{~m}$ above chart datum in 1986. On Great Lakes shores, rising lake levels together with wave action move the bar formations onshore and conversely, during falling lake levels, bars move offshore. Continuous migration of the bar and 

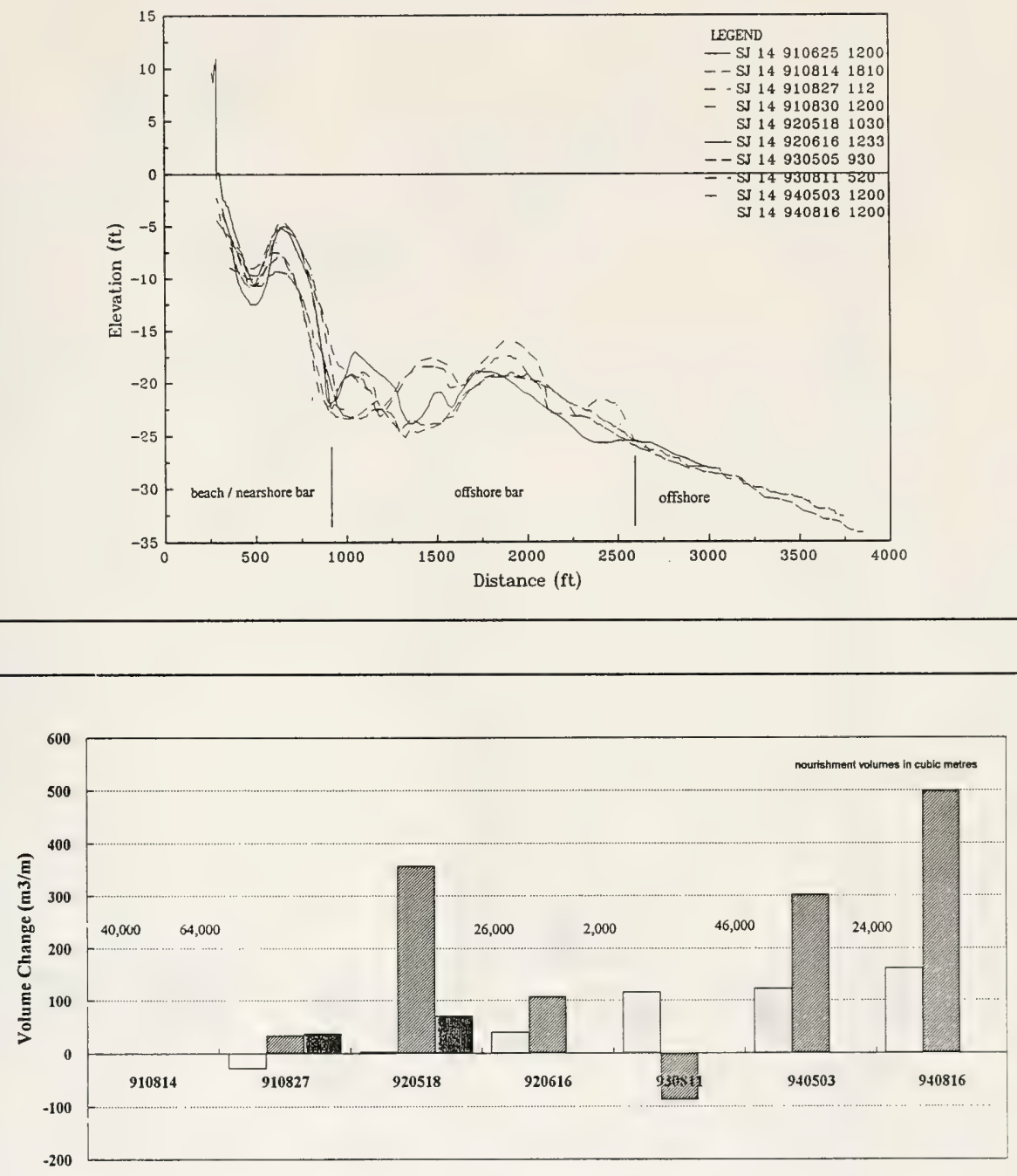

Date

Beach and Nearshore Bar 0 Offshore Bar

Figure 26. Profiles (beach and offshore) for R14 

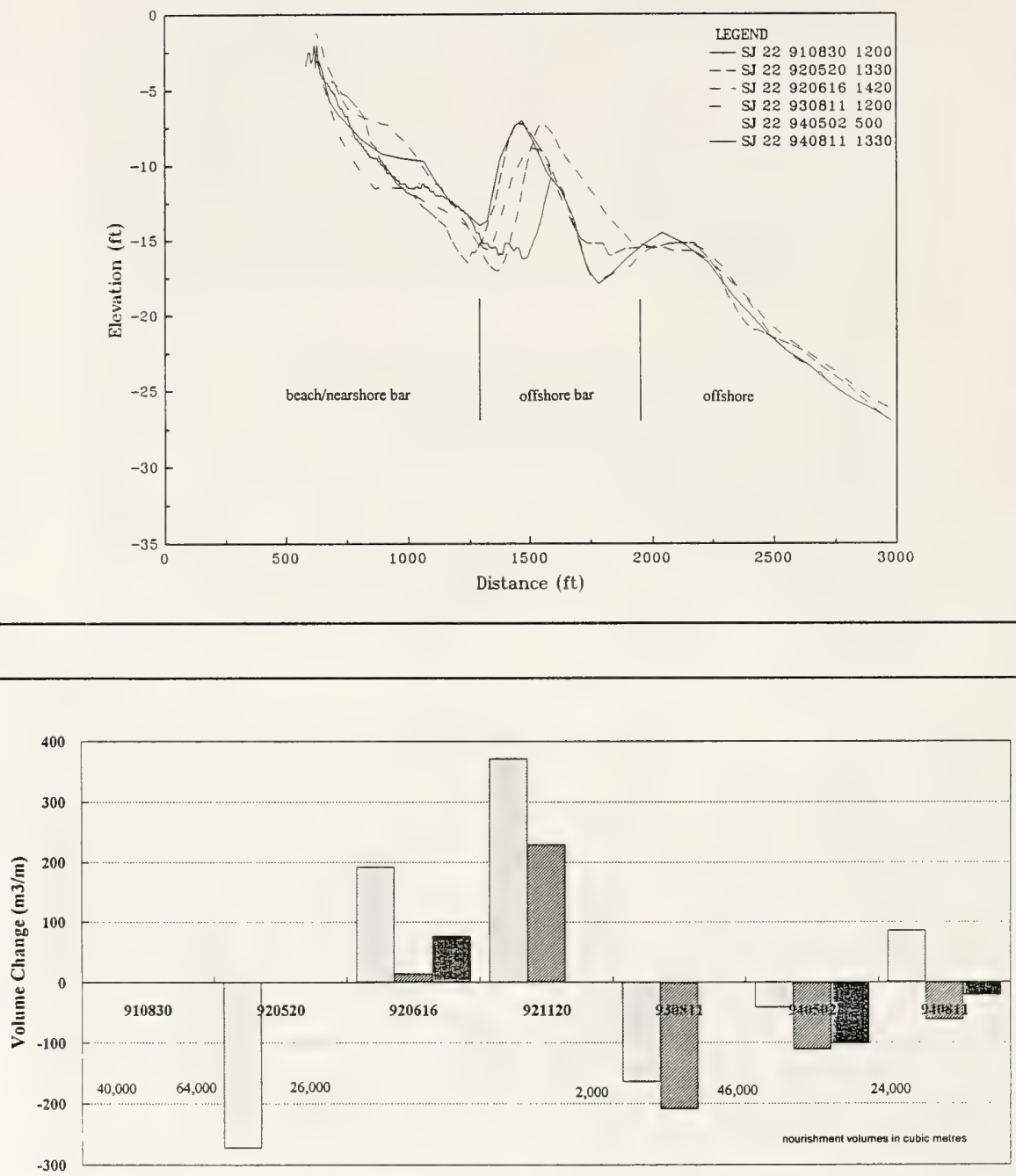

Date

Figure 27. Profiles (beach and offshore) for R22 


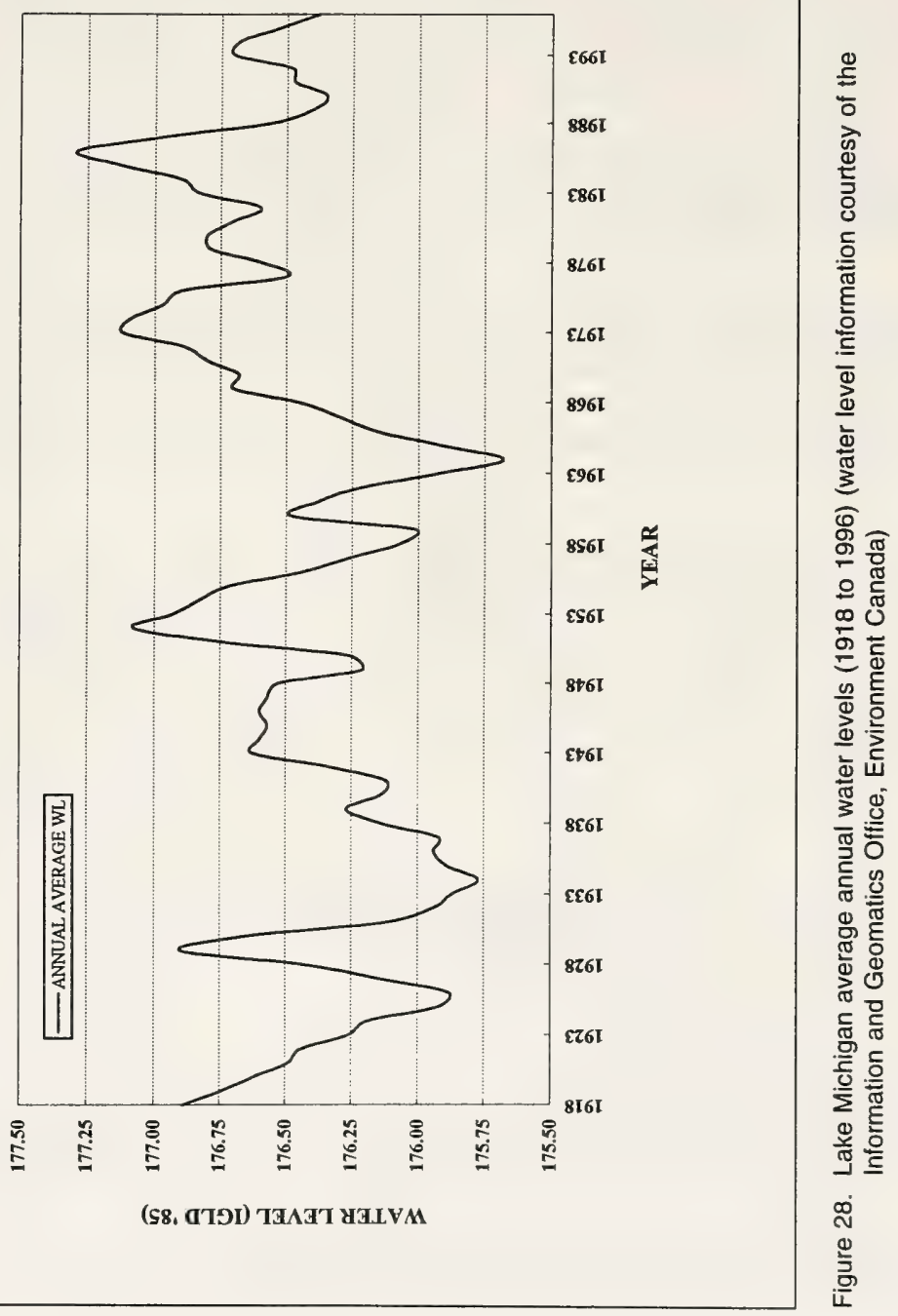


trough features in the nearshore zone in response to fluctuations of water levels distributes the exposure and downcutting of the glacial till across the entire profile.

In a technical paper prepared for the U.S. Army Corps of Engineers, Hands (1979) compared profiles compared for a $55-\mathrm{km}$ stretch of shoreline on eastern Lake Michigan. From 1967 to 1976, the profiles clearly showed the shoreward migration of bar formations with rising lake levels (see Figure 29). Therefore, changes in the position of bars, and the troughs between the bars where the till is often exposed, result from changes in water levels. The range of water level variation on Lake Michigan, explains how the downcutting can be distributed across the entire shoreface.

\section{Bathymetry Comparisons and Sediment Budget Calculations}

The authors recognize that comparisons of bathymetry that was mapped for navigation purposes can sometimes produce misleading results due to the relative inaccuracy of these surveys. However, the extent of lake bed change at

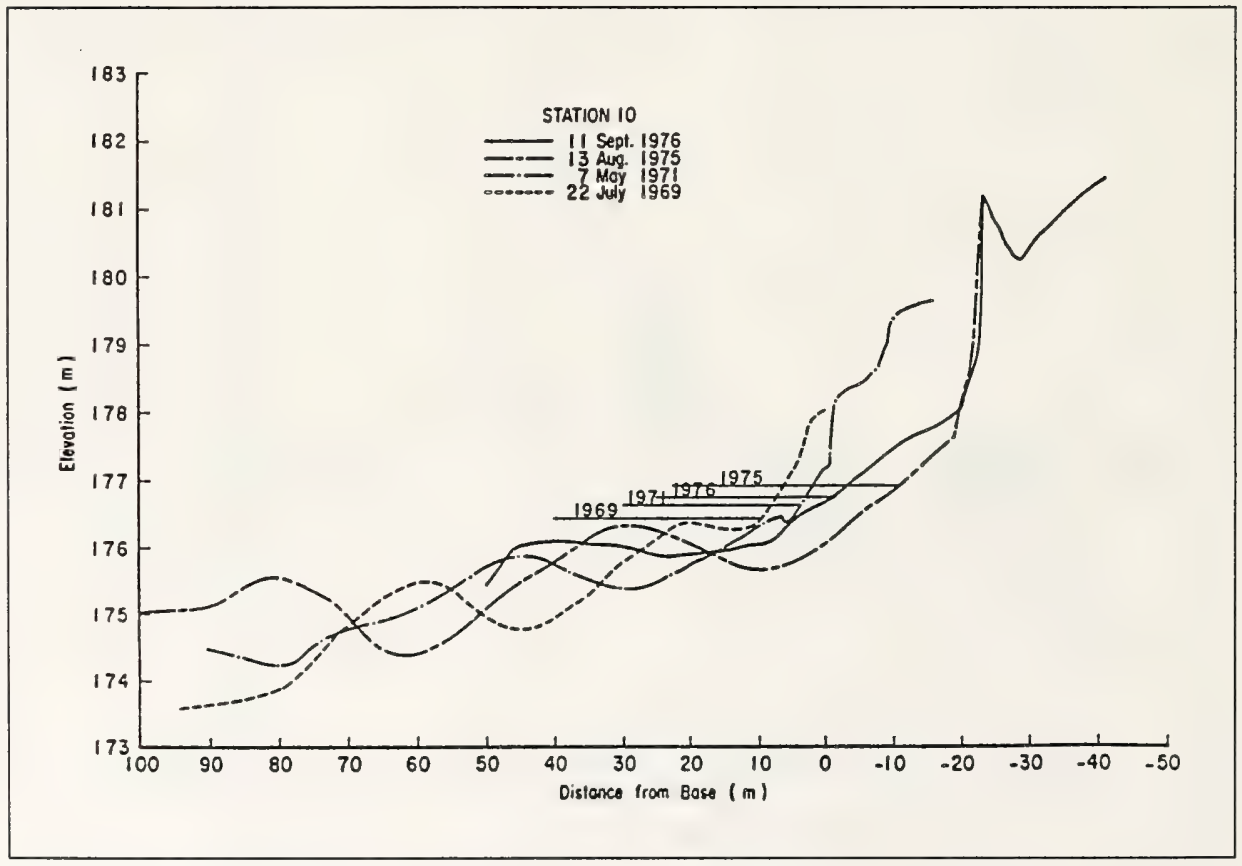

Figure 29. Nearshore bar migration, eastern Lake Michigan (Hands 1979) 
this site is such that this is not an issue. Lake bed lowering is on the order of meters, which is far greater than any possible relative datum or measurement errors in the surveys.

From the extent of the hydrographic surveys, eight panels (or sediment compartments) were created north and south of the harbor jetties. Wherever possible, the panel boundaries were selected to delineate changes in the lake bed evolution characteristics (i.e., south fillet beach, Panel 3 and feeder beach, Panel 4). Data from historic and recent bathymetries were used to create 3-D surfaces representative of the lake bed conditions at the time of the surveys. From the comparison of the 3-D lake bed surfaces, net volume changes were calculated for each individual panel (i.e., a positive value is obtained when the net change for a panel was deposition for the period of the comparison). To provide a relative basis of comparison for the calculated change in panel volumes between the individual periods (i.e., 1945/56 to 1964/65 and 1964/65 to 1991) and panels, the total change in panel volume is divided by the surface area of the individual panel. This provides an averaged depth change for the entire panel, representing an annual rate of erosion or deposition.

\section{$1945 / 46$ to $1964 / 65$}

The 1945 to 1965 bathymetry comparison provides a description of the lake bed evolution downdrift of the harbor jetties before the implementation of the Section 111 Plan for beach nourishment at St. Joseph (Figure 30).

North of the jetties, the average annual lake bed lowering for Panel 1 was $2.7 \mathrm{~cm} /$ year. This rate of lake bed lowering is very similar to Panel $8(2.6 \mathrm{~cm} /$ year), at the southern limit of the bathymetry comparison (see Table 7). This may indicate that Panels 1 and 8 were representative of the background rate of erosion at St. Joseph from 1945 to 1965 . Panel 2 corresponds to the northern fillet deposit, adjacent to the northern jetty at the mouth of the St. Joseph River. The average increase in lake bed elevation was almost $2 \mathrm{~cm} /$ year, with $1.0-3.0 \mathrm{~m}$ of deposition recorded near the northern end of the jetty over the 20-year period.

The southern fillet deposit, Panel 3, experienced minor volume increases, amounting to an average of $0.5 \mathrm{~cm} /$ year for the panel, with the majority of the deposition located adjacent to the shore and southern harbor jetty (see Figure 30).

From Panels 4 to 7, severe lowering of the lake bed occurred between 1945 and 1965. From profiles R8 to R17, a 3-km-long depression in the lake bed developed, with lowering in excess of $4 \mathrm{~m}$ recorded over the 20-year period (see Figure 30). Average lake bed lowering for the four panels (4 to 7) ranged from $5.7-10.0 \mathrm{~cm} /$ year.

The total average annual sediment volume lost from Panels 3 to 8 was $258,000 \mathrm{~m}^{3} /$ year between 1945 and $1964 / 65$. Assuming the long-term average 
LEGEND

(elevation change in metres)

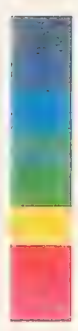

3.0

2.0

1.0

0.0

$-1.0$

$-2.0$

$-3.0$

$-4.0$

$-5.0$

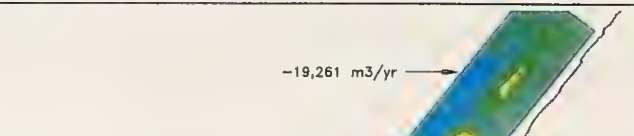$$
\text { ( }
$$

LAKE MICHIGAN

.

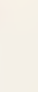


annual net transport rate of $80,000 \mathrm{~m}^{3} /$ year to the south is blocked by the jetties, and must therefore be eroded from the lake bed and shoreline south of the jetties, this leaves an additional $178,000 \mathrm{~m}^{3} /$ year of lake bed erosion that must be related to offshore losses. It is likely that the majority of these losses are related to offshore dispersal of silt and clay associated with the erosion of the cohesive sediment. From these simplified sediment budget calculations, the average annual erosion of the cohesive profile may have been as high as $20 \mathrm{~m}^{3} / \mathrm{m} /$ year for this $9-\mathrm{km}$-long section of shoreline south of the harbor (Panels 3 to 8).

\section{$1964 / 65$ to 1991}

The second period of lake bed evolution corresponds with the introduction of beach nourishment at St. Joseph. From the lake bed surface change plot given in Figure 31 and the volume estimates in Table 7, the 1964 to 1991 comparison clearly represents a period of reduced erosion rates combined with nearshore deposition, both north and south of the harbor jetties. There are several possible explanations for the nearshore deposition: (a) migration of nearshore bars during the high water levels in 1991; (b) deposition associated with the alongshore transport of beach nourishment; and (c) error in bathymetry or datum conversion.

Since the 1991 bathymetry did not extend north of the jetties, the 1964/65 bathymetry was compared to the 1995 survey for Panels 1 and 2. Although Panel 1 continued to erode, the average annual lowering was only 12 percent of the 1945 to 1965 rate (see Table 7). The depositional trend also continued for Panel 2; however, only at 27 percent of the 1945 to 1965 rate. The long narrow depositional feature in Panel 2 (see Figure 31) is associated with a change in bar location (profile change) in response to the difference between the 1964/5 low water levels and the average water levels in 1995.

At the southwestern corner of Panel 2, which corresponds with the end of the north jetty, the $1964 / 65$ to 1991 bathymetry comparison in Figure 31 revealed localized deposition in the range of 1 to $2 \mathrm{~m}$ for the 27-year period. A similar trend was also evident in the $1945 / 6$ to $1964 / 5$ comparison, although the zone of high deposition was located closer to the shore (see Figure 30). A decrease in the offshore depths at the end of the jetty is the direct result of the growth of the fillet beach deposit. This process may also have contributed to the development of a sediment pathway for channel infilling during northwesterly wave attack.

For Panel 3 south of the jetties, the annual erosion rate averaged $0.2 \mathrm{~cm} /$ year. Panels 4 through 7 , which experienced the most extreme erosion between 1945 and 1965, continued their lowering trend, but at dramatically reduced rates. The annual lowering rates for Panels 4 to 7 ranged from $0.2 \mathrm{~cm}$ to $1.1 \mathrm{~cm}$. The total lake bed lowering for the isolated case of the large depression in the lake bed ( $\mathrm{R} 12$ to $\mathrm{R} 20$ ) was in the range of $1-2 \mathrm{~m}$ for this 


\section{LEGEND}

(elevation change in metres)

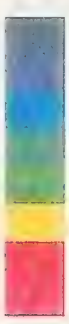

3.0

2.0

1.0

0.0

$-1.0$

$-2.0$

$-3.0$

$-4.0$

$-5.0$

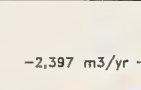


period. The zone of the greatest lowering rates also shifted southward from R9 - R17 to R12 - R20 (refer to Figures 30 and 31).

A comparison of Figures 30 and 31 clearly shows that the highest rates of deposition in the nearshore between 1965 and 1991 correspond to the locations of significant lowering between 1945 and 1965. This would suggest that sand moving in a cross-shore and alongshore direction is partially trapped in the deeper nearshore zones, until the depressions are filled. Consequently, these depressions may be sinks for sand transported from the feeder beach.

The net volume change related to the changes in the lake bed surface (within the panel boundaries) south of the harbor jetties was $-25,000 \mathrm{~m}^{3} /$ year between 1964/65 and 1991. Disregarding the negligible sediment input from shoreline recession and channel bypassing, input to the sediment budget from the beach nourishment averaged $88,000 \mathrm{~m}^{3} /$ year from 1965 to 1991 . Assuming that $80,000 \mathrm{~m}^{3} /$ year of the nourishment sediment is transported in an alongshore direction (due to the southerly directed net transport gradient), and that approximately $8,000 \mathrm{~m}^{3} /$ year may have been lost as annual deposition in the navigation channel, there would be no net gain or loss resulting from alongshore transport processes. Therefore, the annual net change in the sediment budget from the bathymetry comparisons of $-25,000 \mathrm{~m}^{3} /$ year must be largely related to offshore losses. As noted above, offshore losses are probably the result of the erosion of the cohesive sediment and the offshore dispersal of silts and clays. Consequently, for the panels south of the harbor jetties, the volume of irreversible erosion of the cohesive substrate may have been as high as $2.8 \mathrm{~m}^{3} / \mathrm{m} /$ year.

\section{1 to 1995}

The 1991 to 1995 bathymetric comparison is limited to Panels 3 to 8 south of the harbor jetties, as seen in Figure 28, due to the limited surveying done in 1991. During these 4 years the volume changes south of the jetties changed dramatically. Volumetric losses and lake bed lowering were greater than the previous peak during the initial interval (1945 to 1965) (see Table 7).

The most dramatic erosion rates between 1991 and 1995 occurred in a 200-m-wide band along the shoreline, with 1-4 m of lake bed lowering. Depositional areas, seen in Figure 32, are further offshore and do not compensate for the nearshore lowering. There are several possible explanations for the reduced rate of offshore deposition: (a) sand eroded from the nearshore is widely dispersed offshore; (b) sand eroded from the nearshore is transported in an alongshore direction; (c) a significant percentage of the eroded nearshore volumes is glacial till and provides very little sand to the local sediment budget.

The volume loss related to lake bed lowering was approximately $367,000 \mathrm{~m}^{3} /$ year for this period. Disregarding the negligible inputs from shoreline recession (outside of calculated panel volumes) and harbor 
LEGEND

(elevation change in metres)

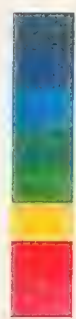

3.0

2.0

1.0

0.0

$-1.0$

$-2.0$

$-3.0$

$-4.0$

$-5.0$

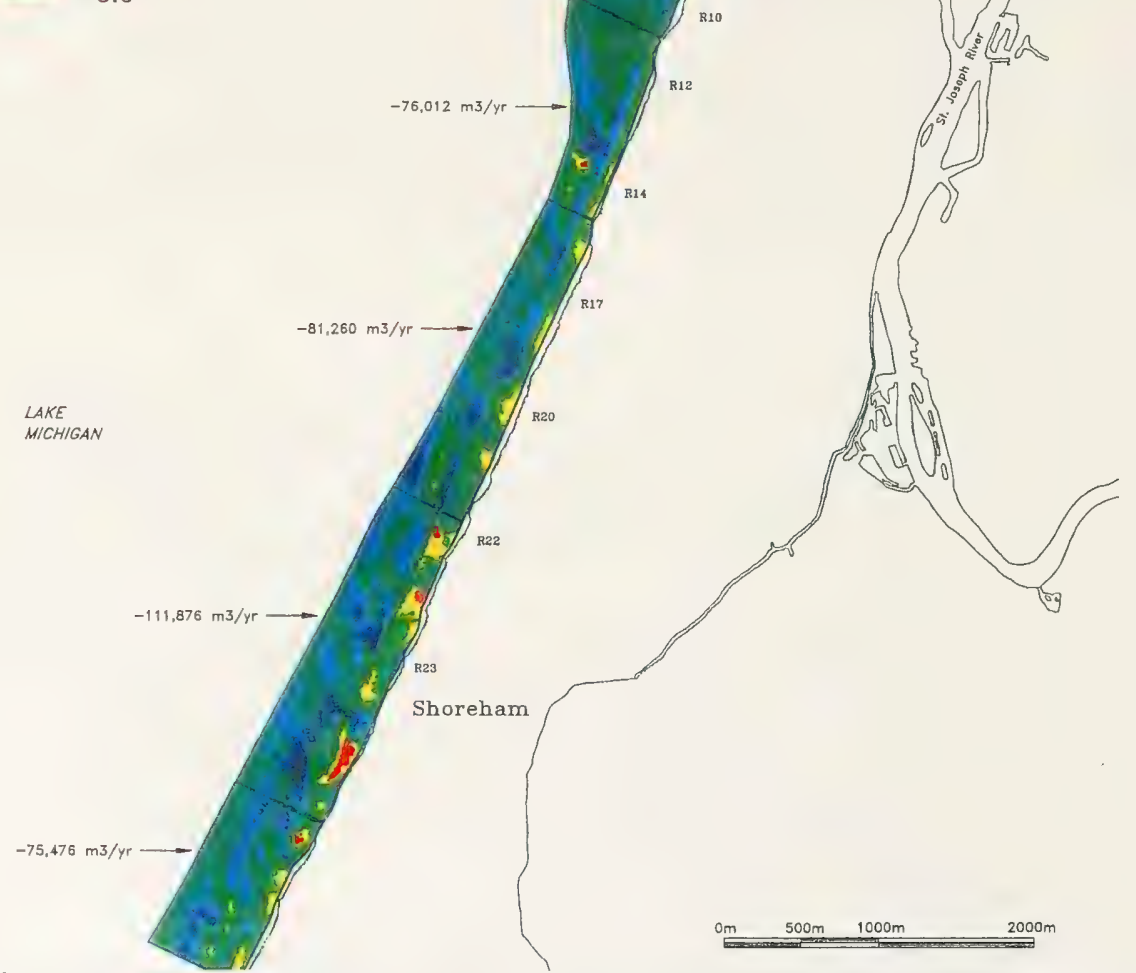

Figure 32. St. Joseph, Lake Michigan contours of lake bed elevation change, 1991 to 1995 
bypassing, approximately $80,000 \mathrm{~m}^{3}$ annually must be eroded from the lake bed to supply the potential for net southerly alongshore transport and an additional $8,000 \mathrm{~m}^{3}$ is lost annually to deposition in the navigation channel. Considering that the annual nourishment volumes between 1991 and 1995 were $41,000 \mathrm{~m}^{3} /$ year, approximately $47,000 \mathrm{~m}^{3} /$ year of lake bed erosion would be required to supply the additional losses to alongshore transport and channel infilling. Consequently, of the $367,000-\mathrm{m}^{3}$ loss related to lake bed lowering, up to $320,000 \mathrm{~m}^{3}$ may have been attributed to the irreversible lowering of the cohesive profile or approximately $35.5 \mathrm{~m}^{3} / \mathrm{m} /$ year.

\section{$1945 / 46$ to 1995}

Figure 33 compares $1945 / 6$ and 1995 bathymetry, and represents 50 years of lake bed evolution at St. Joseph. With the exception of the northern and southern fillets (Panels 2 and 3), the entire lake bed has experienced dramatic lowering. A large depression in the lake bed has been created by 2 to $5 \mathrm{~m}$ of vertical erosion in the nearshore zone between St. Joseph and Shoreham.

Given the approximate size of the depression, over $3,000,000 \mathrm{~m}^{3}$ of sediment has been eroded from the lake bed in the last 50 years. 


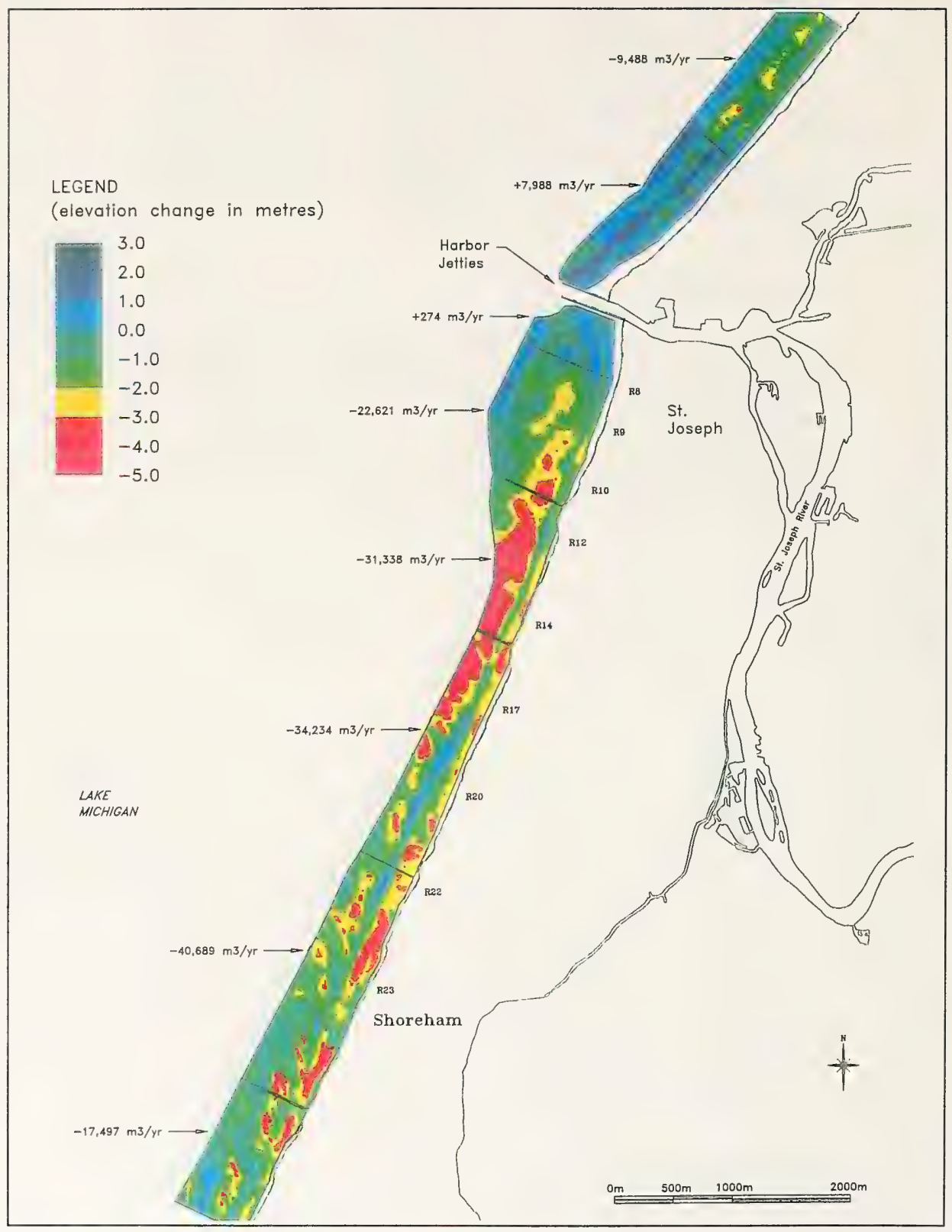

Figure 33. St. Joseph, Lake Michigan contours of lake bed elevation change, 1945/46 to 1995 


\section{Interpretation of Results - A Descriptive Model of Coastal Morphodynamics}

This chapter provides a summary of the study findings in the form of a description of the historic, present, and possible future coastal processes and morphologic evolution for the study area shoreline and lake bed. Two periods are considered for the historic changes spanning the 1945/6,1964/5, and 1991 bathymetry surveys. The present conditions are represented by the changes between 1991 and 1995. The study area shore may be subdivided into seven sectors as follows (see Figure 34):

a. A section of coast north of the harbor which appears to be uninfluenced by the presence of the harbor (i.e., this corresponds to Panel 1 of the lake bed surface comparison analysis).

b. The updrift fillet beach located immediately north of the harbor jetties (i.e., Panel 2).

c. The downdrift fillet beach extending about $400 \mathrm{~m}$ south of the harbor (i.e., Panel 3).

d. The feeder beach area extending from Line R8 to the Waterworks revetment (i.e., Panel 4).

e. A section with uninterrupted shore protection in the form of revetment and seawall from the Waterworks revetment to Line R22 (i.e., Panels 5 and 6).

$f$. The section of unprotected or partially protected shore extending from Line R22 to south of Shoreham; (i.e., Panel 7).

g. A section at the southerly limit of the study area which, historically, does not appear to have been influenced by the harbor jetties (i.e., Panel 8). 


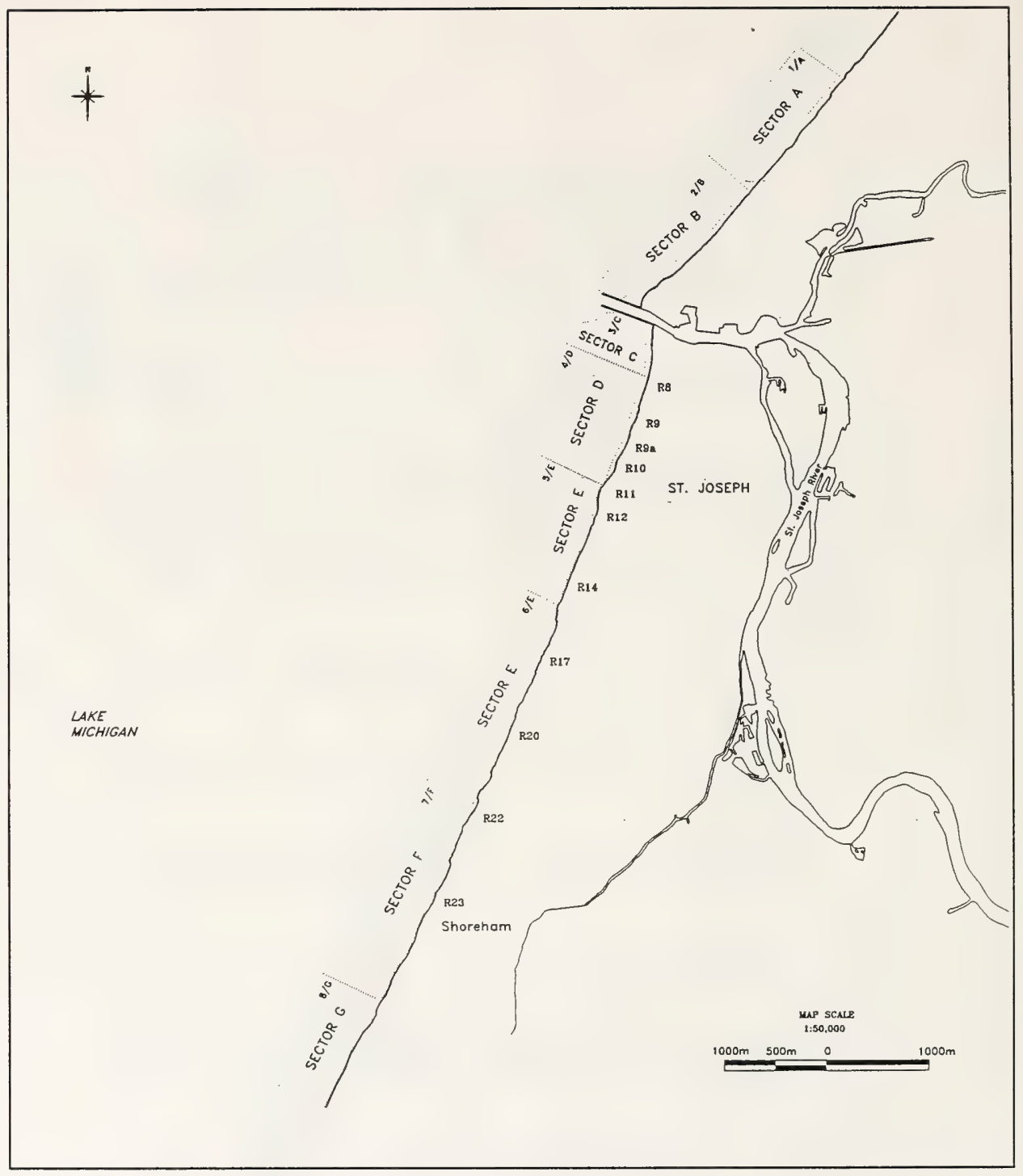

Figure 34. Sector locations 
The descriptive model of coastal morphodynamics for the historic, present, and future conditions at St. Joseph is illustrated in Figures 35 - 37. For each period, the descriptive model summarizes the findings of the lake bed surface comparisons, dredging and nourishment volumes, recession rates, and representative estimates of alongshore sediment transport. Any variation in the transport rates between the different periods only reflects changes to the representative nearshore profiles used as model input with the average annual wave climate from 1956 to 1987 . Qualitative information from the analysis of lake levels, profile comparisons, and COSMOS 2D/3D modeling presented in Chapter 4 is also incorporated in the descriptive model.

\section{Historic Conditions}

\section{$1945 / 6$ to $1964 / 5$}

Descriptive model results for 1945 to 1965 are summarized in Figure 35. Current understanding of coastal processes for cohesive environments would suggest that the shoreline of Sector $A$ has been eroding since the glaciers receded several thousand years ago. Analysis of air photo information dating back to 1939 indicates that the recent long-term recession rate is about $0.8 \mathrm{~m}$ / year (see Section of Chapter 2 entitled "Shoreline Recession"). The average lowering rate for Panel 1 was found to be $2.7 \mathrm{~cm} /$ year for the period from 1945 to 1965 . This rate of erosion compares well to the situation in Sector G during this period (i.e. at the south end of the project area), which featured a recession rate of about $0.9 \mathrm{~m} / \mathrm{year}$ and an averaged lowering rate of $2.6 \mathrm{~cm} /$ year. Based on this finding, and on the fact that these recession rates are similar to those found in areas further to the north and south of the harbor (i.e., well beyond any zone of harbor influence), the authors suggest that these two sectors are representative of the "background" erosion conditions related to cohesive shore processes and are not strongly influenced by the presence of the harbor jetties, at least for historic periods. This is an important finding because the Section 111 program is only intended to mitigate erosion related to the presence of the structure and not the background erosion.

The fillet beaches immediately north and south of the St. Joseph River mouth (Sectors B and C) have been stable or accreting at least since the construction of the jetties in 1903. Numerical modeling results indicate that significant quantities of sediment may be deposited in these areas during storms. The bypassing analysis showed that the combination of the long jetties and the deep navigation channel acts as a total littoral barrier, trapping all sediment reaching this area from either the north or the south.

Somewhere in Sector D (i.e., the feeder beach), the shore changes from sandy to cohesive as the bank of the incised river valley is encountered. MDNR calculations of long-term recession rates indicate that the entire reach of Sector D has been eroding, with recession rates between 0.35 and $1.15 \mathrm{~m} /$ year over the last 50 years (with the larger rates occurring immediately north of the Waterworks revetment). 


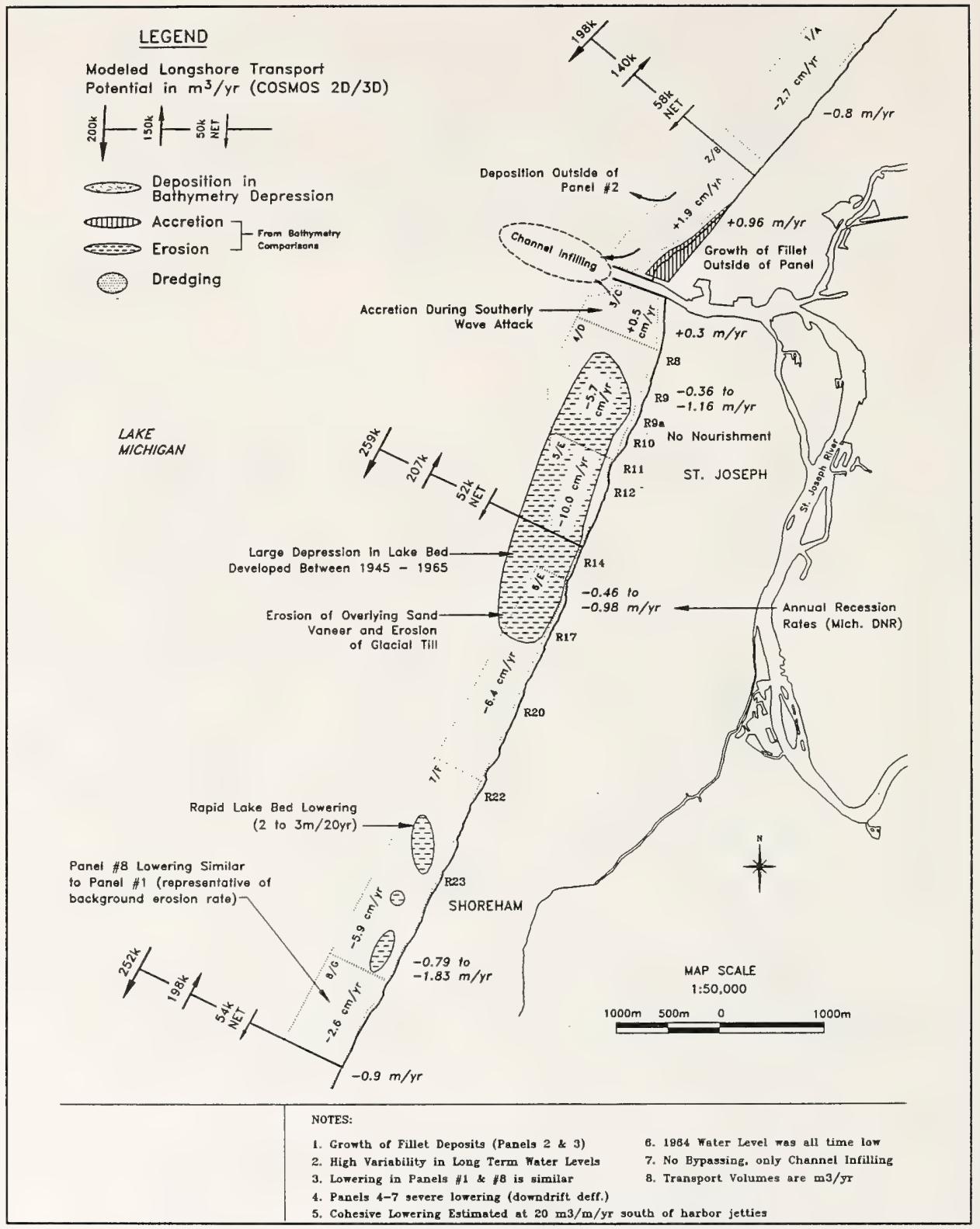

Figure 35. 1945 to 1965 descriptive model 


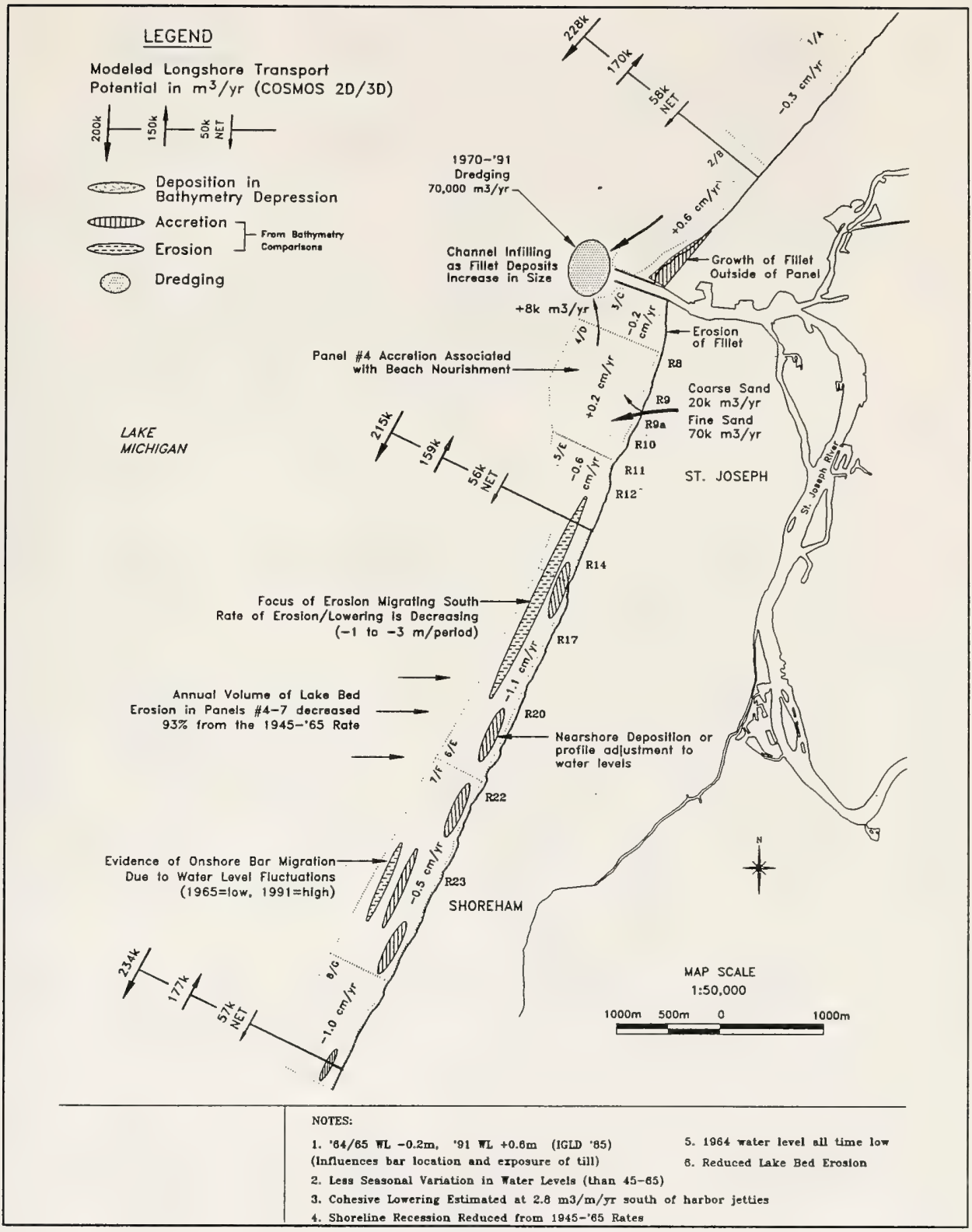

Figure 36.1965 to 1991 descriptive model 


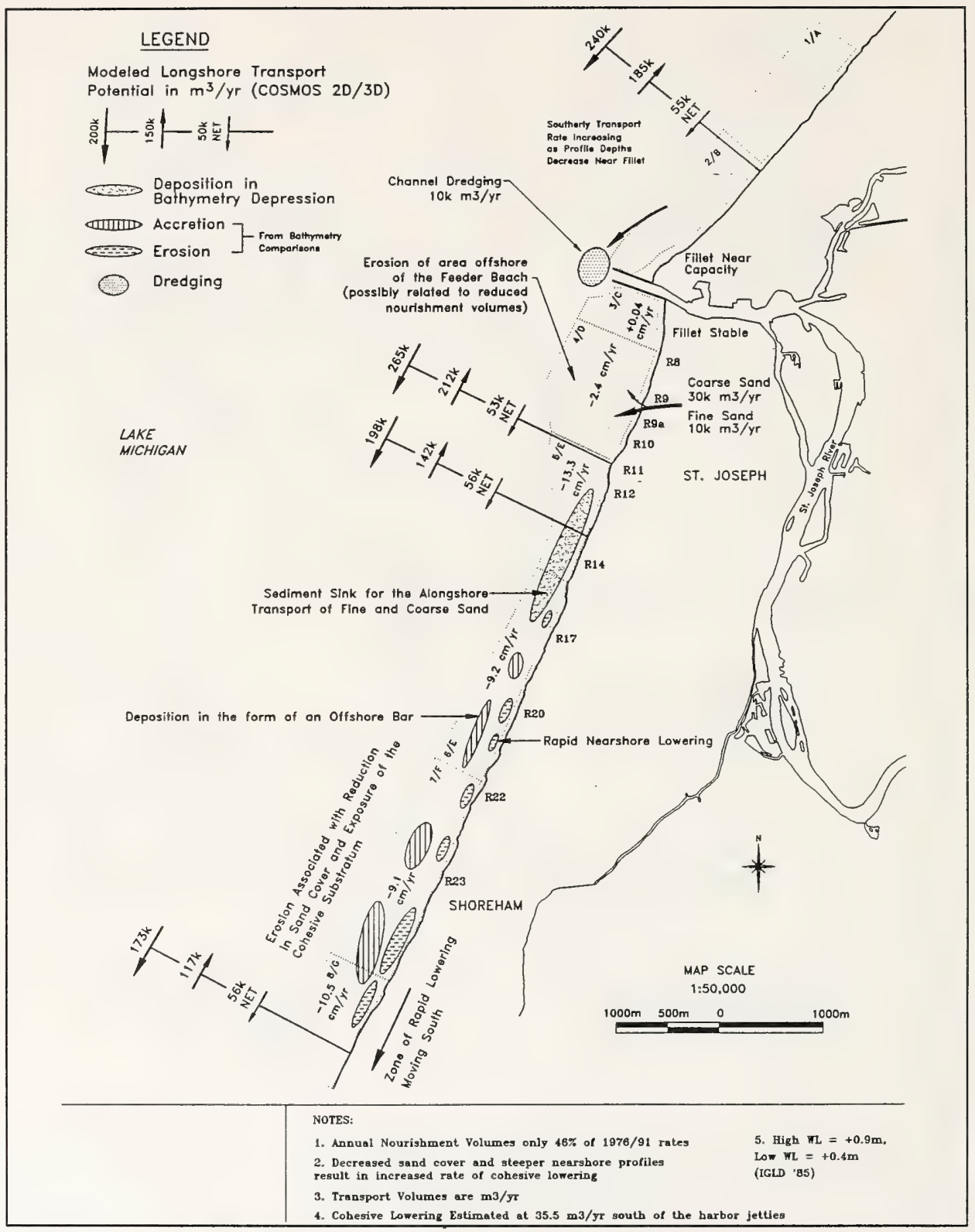

Figure 37. 1991 to 1995 descriptive model 
Sector E consists of a 4-km-long stretch of uninterrupted shoreline protection. There is a transition zone between the feeder beach and the deeper profiles offshore of the revetment protecting the railway further to the south. The profile for Line R12 shows that significant lake bed lowering in front of the revetment at this area has not yet occurred (see Figure 30). However, further offshore, 4 to $5 \mathrm{~m}$ of lake bed lowering occurred from 1945 to 1995 . Both the numerical modeling results and observations from aerial photos show that the beach located immediately south of the Waterworks revetment is subject to large fluctuations. The revetment itself probably acts as a groin structure impounding at least some sediment to protect the underlying glacial till in the nearshore zone most of the time at Line R12.

Sectors $\mathrm{F}$ and $\mathrm{G}$ consist of the section of coast extending from Line R22 to south of Shoreham. Here, the shore is only partly protected or entirely unprotected. This section features long-term recession rates of 1 to $2 \mathrm{~m} /$ year between 1945/6 and 1964/5.

\section{$1964 / 65$ to 1991}

The $1964 / 65$ to 1991 period is characterized by much lower rates of deposition or erosion in the nearshore zone (see Figure 29) when compared to the earlier 1945 to $1964 / 5$ period (see Figure 30). The possibility that the 1991 bathymetry featured an error in vertical control or datum conversion was investigated and dismissed as a possible explanation for the discrepancy between the rates of change between the two periods. An extensive review of all original data and datum conversions applied to the hydrographic surveys did not identify any errors. The observation of low erosion rates in Sectors A and G, which were previously identified as representative of the background erosion condition, coupled with a low deposition rate in the Sector B fillet and erosion in the Sector $\mathrm{C}$ fillet located south of the harbor, suggests that the driving force of erosion and deposition (i.e., wave-driven sediment transport) may have been less effective than during the previous period (see Figure 36). Unfortunately, the available wave climate information only extends back to 1956, and it is not possible to substantiate this hypothesis.

A more certain explanation for reduced lake bed lowering rates in Sectors $\mathrm{D}, \mathrm{E}$, and $\mathrm{F}$ is the influence of the Section 111 beach nourishment program, which was initiated in 1976 (with some nourishment placed as early as 1970). In these sectors, there was a tenfold decrease in the lake bed lowering rates. In Sector G, representative of background conditions, the lake bed erosion rate was lower by a factor of only 2.5 . The trend for this period suggested that the Section 111 Program was successful in mitigating the lake bed lowering rates for Sectors D to F. While it may be argued that a beneficial effect was also experienced in Sector G, it is more likely that the reduced erosion rate in this sector can be explained by generally lower driving forces during this period as mentioned in the previous paragraph. 
It should be noted that the tenfold reduction in lake bed lowering rates may not be sufficient with respect to mitigation of the harbor influence on erosion further downdrift. If the feeder beach sand simply ends up slowly filling the large lake bed depression that has developed in Sectors D to F, the shore further downdrift will continue to be denied the historic levels of sediment supply.

\section{Existing and Future Conditions}

\section{Existing conditions (1991 to 1995)}

Comparison of the lake bed surfaces from the 1991 and 1995 hydrographic surveys reveals a rapid acceleration in lake bed lowering. In Sectors $\mathbf{E}$ to $\mathbf{F}$, the lake bed lowering rates are 30 to 50 percent higher than the $1945 / 6$ to $1964 / 5$ comparison period and an order of magnitude greater than the 1965 to 1991 period (see Table 7). Of greatest concem is the observation that the rate of lake bed lowering in Sector $G$ is of a similar magnitude to that of Sectors $E$ to $F$ (see Figure 37). In other words, it would appear that Sector G is now being influenced by the harbor structure and may no longer be regarded as representative of background erosion. A review of the contour plots of lake bed change (see Figure 32) also indicates that the focus of lake bed lowering (i.e., that led to the development of the depression offshore of Sectors $E$ to F) has shifted to the south.

One significant difference between this most recent period and the previous comparison period was the annual average volume of beach nourishment. Annual placement volumes have been reduced by approximately 50 percent to $40,000 \mathrm{~m}^{3}$ over the last 5 years (see Figure 2). The reduced level of beach feeding may at least partly explain the accelerated erosion rates.

\section{Projections of future conditions}

The fillet beach south of the harbor is currently stable or slightly accreting. During southwest storms, this sector receives sediment from erosion in the feeder beach area. It would appear that the fillet has reached its maximum extent and that any additional sand transported northwards eventually makes its way into the navigation channel where it is deposited, and later dredged.

The feeder beach shoreline is maintained at a stable average position with the annual beach nourishment. Without the nourishment, the numerical model investigations have shown that shoreline recession would recommence, with the transport of sand to the south and the uncovering and downcutting of underlying glacial till where it exists. Comparison of the 1991 to 1995 lake bed surfaces in Figure 32 revealed that this sector experienced erosion under the recently reduced nourishment levels. A summary of the changes to the 
profile lines in this sector (i.e., Lines R8 to R11) over the period from 1991 to 1993 is given in Table 10. This table indicates that each beach nourishment is followed by rapid profile adjustment (PA) or moderate to high erosion (ME to $\mathrm{HE})$.

\section{Table 10 \\ St. Joseph Harbor, Lake Michigan, Summary of Profile Data (Beach Fills, Profile Change, and Wave Energy)}

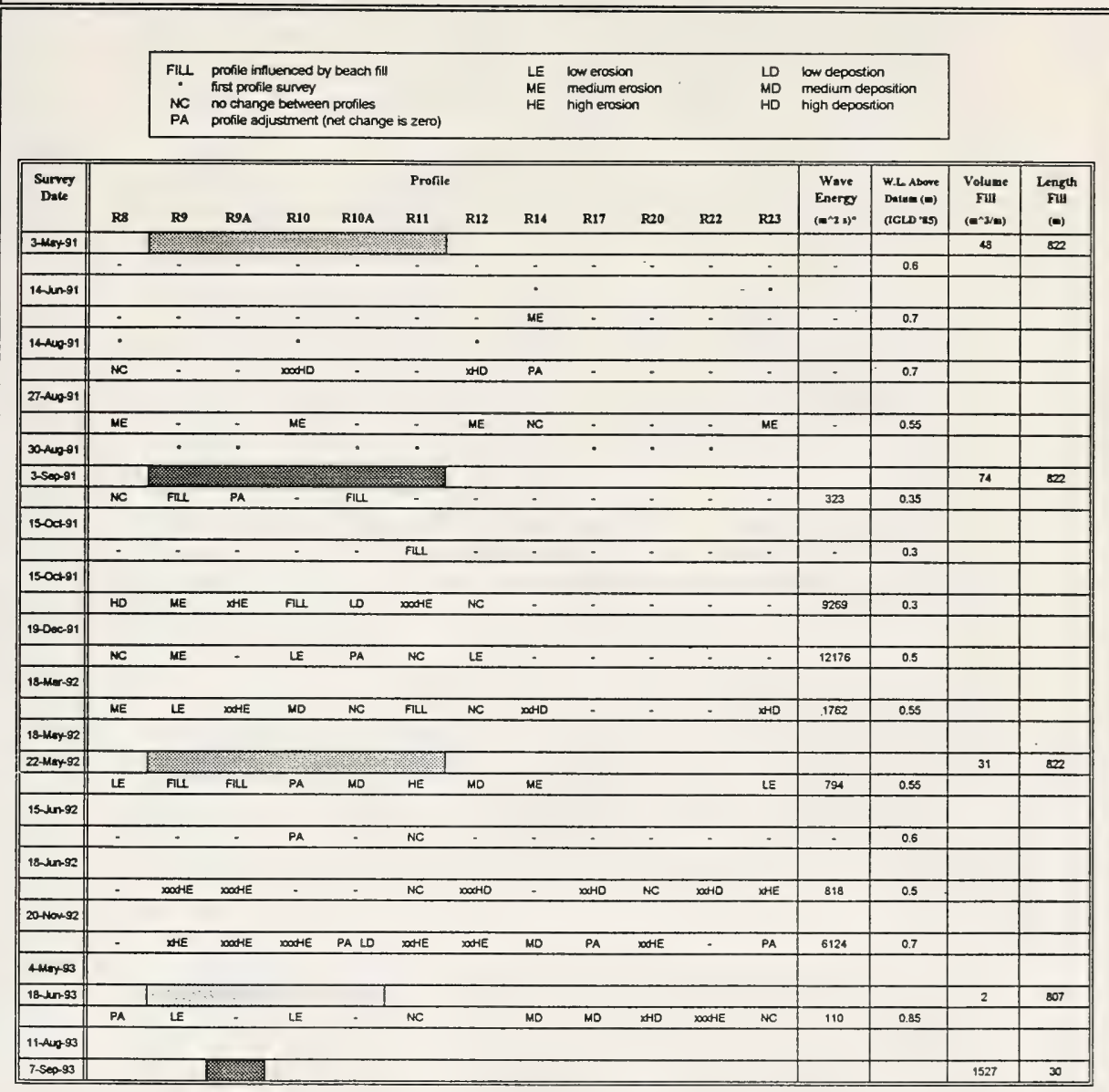

Note: Wave energy $\left(\mathrm{m}^{2} \mathrm{~s}\right)$ is $\mathrm{H}^{2} * \mathrm{~T}$ (wave height squared $\times$ wave period) provides indication of relative wave energy. 
The transition area of Sector E from the Waterworks revetment to south of Line R12 is distinguished by an ephemeral beach feature (i.e., a beach subject to significant fluctuation in size). Table 10 indicates that in two of the three years of the monitoring program, this sector experienced deposition towards early fall (as a resuit of the beachfill moving south) and erosion in late fall as the deposit was eroded by subsequent storms. Results of the model tests indicate that this sector is subject to the highest alongshore transport rates for the study area shoreline. Numerical model results also indicate that this area is subject to ongoing downcutting, particularly offshore of the beach deposit. As noted in the section entitled " $1945 / 6$ to $1964 / 5$," the Waterworks revetment probably helps to impound sediment and maintain the beach immediately south of the revetment. Numerical model tests also revealed that the coarse-grained beachfill derived from upland sources is much more effective at protecting the glacial till under the beach in this sector.

Although downcutting of the nearshore profile in Sectors E and F may eventually diminish owing to the deeper water that has developed offshore of the shore protection, the numerical model results suggest it is still ongoing, as did the 1991 to 1995 lake bed comparison (see Figure 32). Model results also indicate that there may be ongoing deposition of sand in this sector, since only about 50 percent of the coarse sediment transported into this sector from the north is predicted to be transported southwards beyond Line R23. It was seen that during the 1965 to 1991 period with higher annual beach nourishment volumes, the rates of nearshore profile lowering in this sector were significantly reduced (see Table 7). Table 10 shows that this sector typically receives sediment sometime in mid to late fall. Based on the predicted reduction in potential transport rates of coarse sediment between Line R12 and Line $\mathrm{R} 23$, we estimate that about half of the $600,000 \mathrm{~m}^{3}$ of coarse fill that has been placed since the beginning of the Section 111 nourishment program has been deposited in this sector. With this assumption, and assuming the deposition occurs over a 500-m-wide band of the shore extending out to the 6 -m contour, the average gain in thickness of sand cover would be $0.067 \mathrm{~m}$ since 1976 . Based on the findings of lake bed surface comparisons and the results of the numerical model tests, this annual deposition rate of $0.0035 \mathrm{~m} /$ year derived from the beach nourishment is at least balanced, and probably outpaced by the ongoing downcutting of the underlying glacial till. This was certainly the case during the 1991 to 1995 period, with lower annual beach nourishment volumes.

In order to raise the profiles to the historic lake bed levels (i.e., to allow unimpeded sediment transport to the south), and assuming about half of the traditional coarse beach nourishment volume (i.e., about $20,000 \mathrm{~m}^{3} /$ year since 1986 ) is deposited in this sector and that downcutting can be arrested in the near future, almost 8 million $\mathrm{m}^{3}$ of sediment would be required over the next 400 years at the current rate of nourishment. The numerical model tests indicated that the $2-\mathrm{mm}$ grain size sediment was no more effective than the $0.2-\mathrm{mm}$ sediment in protecting the underlying till from exposure and downcutting in this sector. 
The most southerly sector, Sector G, and the unprotected shoreline further to the south received about half of the historic net alongshore sediment supply rate of coarse sediment. This is because the deep water offshore of Sector D acts as a sink for about 50 percent of the coarse beachfill sediment. Therefore, it is likely that the shoreline of Sector G, and particularly the shore to the south of this sector, are suffering due to a depletion of the historic sand cover with the associated increased exposure of the underlying till and increased downcutting and shoreline recession rates. The loss of the coarse fraction results in greater erosion close to shore (i.e., where slopes are steeper and only the coarse-grain-size fractions remain relatively stable under most conditions). The most recent lake bed comparison (1991 to 1995) revealed that the lowering had in fact increased dramatically in Sector $\mathrm{G}$ compared to earlier periods.

\section{Comments on the Effectiveness of the Beach Nourishment Program}

The fillet beach of Sector C would probably remain stable without beach nourishment from the Section 111 program. At present, perhaps as much as 50 percent of the sand placed in the feeder beach area (particularly for the dredged finer sediment) ends up back in the navigation channel from where it was originally removed (and will be removed again).

There must be a more cost-effective approach to maintaining the position of the shoreline in Sector D than beach renourishment. An alternative approach may also be more environmentally acceptable and less disruptive to the local community (i.e., not requiring the annual trucking operation for the placement of coarse sand and gravel).

The primary local beneficiary of the ongoing nourishment is the transitional part of Sector E. Here, too, there may be more cost-effective means of protecting this section of shoreline. The coarse sediment is much more effective than the fine in protecting the till underneath the beach in this sector. The coarse sediment fulfills a role (which would have been present historically) in protecting the underlying till from downcutting that the fine sediment cannot (i.e., over the steeper nearshore slopes).

Sector $\mathrm{E}$ has been a sink, possibly for up to 50 percent of the coarse sediment placed in the feeder beach area. However, the effectiveness of this sediment (whether the coarse grain or fine grain type) in counteracting the ongoing downcutting (either presently or in the future) is questionable. There may be more cost-effective means of protecting the toe of the existing structures. It is unlikely that the placement of the 8 million $\mathrm{m}^{3}$ of beach nourishment required to completely fill the depression that has developed over time is justifiable. 
During the period from 1986 to 1995 , Sector $\mathrm{G}$ and the area to the south received perhaps 50 percent of the coarse sediment eroded from the feeder beach. Therefore, this sector and the shoreline to the south experience a deficit compared to the historic sediment supply. This situation, combined with the depleted supply during the years prior to 1976, must have resulted in decreased sediment cover in this area and may have caused an increase in downcutting and shoreline recession. Comparison of the 1991 and 1995 lake bed bathymetries indicates the problem of accelerated offshore lowering and the related shoreline recession has extended south of Sector G.

It would be much more effective to place the entire annual allotment of beach nourishment (or at least the trucked coarse sediment) south of Lines R22 or R23 where it would be 100 percent effective in supplying the downdrift shores. The erosion problems in the study area could be addressed with sitespecific solutions. With this action, the implementation of further shoreline structures to the south of Line 22, to counteract the increased erosion, may be avoided.

\section{Recommendations for Future Monitoring}

The following monitoring activities should be continued to assess the effectiveness of modifications to the beach nourishment program.

a. Aerial photos should be continued to monitor the level of shoreline protection in and south of Sectors F and G.

b. Aerial photos should be regularly analyzed to monitor recession rates in and south of Sections F and G to update the MDNR data.

c. Lines R12 to R23 and new lines further to the south should be monitored regularly to improve understanding of the lake bed changes in these areas.

d. A complete survey of the lake bed, both north and south of the harbor jetties, should be completed 5 to 10 years after the 1995 SHOALS survey, or after significant modification to the beach nourishment program. 


\section{Beach Nourishment Design Guidelines}

Based on the findings of this investigation and the knowledge of cohesive shores that has developed since the early 1980's, some general design guidelines are presented for the specific circumstances of St. Joseph, and for some general categories of cohesive shore situations.

\section{Recommendations for St. Joseph}

Lowering of the lake bed offshore of the MDOT and C\&O revetment (i.e., Sector E in Figure 34) is a result of both the interruption of alongshore transport (particularly prior to the initiation of the Section 111 program) and the stabilization of the shoreline position related to the construction of the revetment.

The present beach nourishment program does not appear to provide any significant benefit to the stability of the revetment along the Sector E shoreline or to the lake bed offshore of the revetment. This is despite the fact that perhaps 50 percent of the beachfill sediment is deposited permanently on the lake bed in this sector, and volume losses dropped to less than one fifth their former 20-year average during the 30 years after nourishment was initiated.

Beach nourishment is definitely effective at maintaining a stable shoreline position in Sector D. The coarse grain sediment is an essential component which protects the till under the upper beach from downcutting during stoms. Fine-grain nourishment on its own (i.e., from dredging alone) is, however, insufficient to protect the underlying till from exposure and downcutting.

Placement of unrestricted beachfill (i.e., without any substantial retaining structures such as headlands) is probably not a cost-effective means of maintaining an average stable shoreline position. A solution to retaining a permanent beach at this location should be sought through the use of rock headlands or breakwaters. It may be argued that this is not the intention of the Section 111 program; however, it must be recognized that this has been the 
result of and would continue to be the result of an unmodified nourishment program.

The greatest flaw in the current nourishment program is that the area where a supply of sediment is most urgently required is only receiving 50 percent or less of the historic supply rate of coarse sediment. This seems to have accelerated recession rates for the shoreline south of the study area (i.e., Sectors G and southward 1991 - 1995). These erosion pressures result in construction of more shoreline protection by property owners. In the long term, these actions only further aggravate the problem by further reducing the supply rate (by eliminating the input of sediment from shoreline erosion and by impeding alongshore transport as deep water develops offshore of the structures).

The authors recommend that beach nourishment be placed downdrift of Line R22 so that 100 percent of the fill reaches the area where it is required (i.e., versus the current situation where perhaps 50 percent or less of the coarse beach nourishment is deposited in Sector E without any apparent benefits). The nourishment should consist of both fine (dredged) and coarse grain components. By moving the feeder beach to the south, the sedimentation rate experienced in the navigation channel should be significantly reduced. As a result, maintenance dredging costs may be reduced if less frequent channel dredging is needed.

\section{General Recommendation for Beach Nourishment on Cohesive Shores Downdrift of Harbor Structures}

It must be recognized that cohesive shores have very different erosion characteristics from sandy shores and this has a significant impact on the downdrift nourishment requirements. In addition, there are varying degrees of cohesive shores (related to the extent and role of the overlying sand cover), which also have an important influence on the nourishment requirements.

Furthermore, effective downdrift nourishment requirements must be determined in light of changes to the lake bed that may have occurred as a result of the presence of the harbor structures prior to the initiation of a nourishment program. This is not necessarily the case for sandy shores downdrift of harbor structures.

Beach nourishment guidelines for the two extremes of cohesive shore conditions (with respect to extent of historic, predevelopment sand cover) are discussed here. A final special condition is also considered.

In some cases, sections of cohesive shore on the Great Lakes (and elsewhere) will feature only a "limited" sand cover. As a possible defining variable, the sand cover between the 4-m depth contour and the bluff would 
have a volume of less than $100 \mathrm{~m}^{3} / \mathrm{m}$ in these cases. Under these conditions, the underlying glacial till is either only thinly covered (i.e., with beach and bar thickness of less than $1 \mathrm{~m}$ ) or entirely exposed. In other words, the till is frequently exposed over the entire profile to conditions of active downcutting. In these situations, it is not clear that the impoundment of sand in an updrift fillet beach, and the deprivation of this sand from the downdrift beaches and lake bed will have any measurable impact on the rate of lake bed downcutting and the associated rate of shoreline recession. This hypothesis was successfully applied in the Port Burwell (north central shore of Lake Erie) litigation case where the Government of Canada successfully defended against a \$30-million claim which held that the harbor structures at Port Burwell had caused accelerated recession for $40 \mathrm{~km}$ of downdrift cohesive shore (see Philpott (1986)).

The opposite extreme consists of a situation where the glacial till underneath the sand cover is rarely, if ever, exposed in the natural condition (prior to the construction of harbor jetties). This situation has been documented for the Illinois shoreline north of Chicago by Shabica and Pranschke (1994). In this case, the interception and impoundment of alongshore sediment by large shore-perpendicular structures has resulted in a reduction of sand cover from over $500 \mathrm{~m}^{3} / \mathrm{m}$ to less than $200 \mathrm{~m}^{3} / \mathrm{m}$ in places. In this case, the reduced sand cover resulting from the impoundment at the shore-perpendicular structures results in accelerated shoreline recession along the downdrift shore. Beach nourishment is required in these cases, not only to reinstate the historic sediment supply rate, but also to replenish the sand cover to its historic level. The latter requirement may be achieved through augmenting the sand cover volume to its natural level (this may not be practical or realistic owing to the large volumes required). Otherwise, the requirement may be relaxed if the effectiveness of the protective characteristics of the overlying sand cover can be augmented. The protectiveness of the sand cover could be improved through the provision of sediment which is coarser than the natural or native sediment. Specific grain size requirements should be determined based on the profile shape, properties of the underlying till, wave exposure, and sediment transport characteristics (both alongshore and crossshore).

A special condition of cohesive shore which may be relatively common relates to cases where the natural profile shape is convex instead of concave (see Stewart and Pope (1993)). Gray and Wilkinson (1979) document the existence of this type of cohesive shore at locations on the east shoreline of Lake Michigan north of St. Joseph. This condition is a result of the presence of a more erosion-resistant surface in the nearshore. The protected nearshore shelf may consist of some form of bedrock or glacial till that is armored by a boulder and cobble lag deposit. Shoreline (or bluff) recession on this type of cohesive shore is particularly sensitive to changes in lake level. While downdrift nourishment requirements for this type of cohesive shore may be less in volume (i.e., less than what might be determined based on potential transport rates), the timing and grain size characteristic requirements should be carefully considered. 
In summary, the nourishment requirements for cohesive shores downdrift of harbor structures (or other impediments to alongshore transport) are more complicated than the requirements for similar situations on sandy shores. The requirements must be established on a site-specific basis. They may vary from cases where no beach nourishment is required to others where the natural supply must be completely replaced and/or augmented with coarse grain sediment. 


\section{References}

Foster, D. S., Brill, A. L., Folger, D. W., Andrensen, C., Carroll, D. G., Fromm, G. L., and Seidel, D. R. (1992). "Preliminary results of a pilot study conducted between St. Joseph, Michigan and Michigan City, Indiana," U.S. Geological Survey Open File Report 92-348, Woods Hole, MA.

Gray, D. H., and Wilkinson, B. H. (1979). "Influence of nearshore till lithology on lateral variations in coastal recession rate along southeastem Lake Michigan," J. of Great Lakes Res. 5(1), 78-83.

Hands, E. B. (1970). "A geomorphic map of the Lake Michigan shoreline." Proceedings of the 13th Conference on Great Lakes Research, Buffalo, NY. American Society of Civil Engineers, NY, Intemational Association for Great Lakes Research, Ann Arbor, MI, 250-65.

- (1976). "Some data points of erosion and flooding for subsiding coastal regions." Proceedings of the 2 nd International Symposium on Land Subsidence. Anaheim, CA, International Association of Hydrological Sciences, Washington, DC, 629-45.

. (1979). "Changes in rates of shore retreat, Lake Michigan, 1967-76," Technical Paper No. 79-4, Coastal Engineering Research Center, U.S. Army Engineer Waterways Experiment Station, Vicksburg, MS, 62-63.

Hubertz, J. M., Driver, D. B., and Reinhard, R. D. (1991). "Wave information studies of the U.S. coastlines, hindcast wave information for the Great Lakes," WIS Report 22, U.S. Army Engineer Waterways Experiment Station, Vicksburg, MS.

Johnson, C. N. (1992). "Mitigation of harbor caused shore erosion with beach nourishment delayed mitigation." Coastal Engineering Practice '92, American Society of Civil Engineers, New York, 137-53.

Nairn, R. B. (1993). "Quasi-3DH morphodynamic modelling: Development, validation and testing." Proc. Canadian Coastal Conference. Canadian Coastal Science and Engineering Association, Vancouver, Ottawa, Canada, 485-97. 
Nairn, R. B., and Southgate, H. N. (1993). "Deterministic profile modelling of nearshore processes; Part 2, Sediment transport and beach profile development," Coastal Engineering 19, 57-96. Elsevier, Amsterdam.

Parson, L. E. (1992). "An example of coarse grained beach nourishment: St. Joseph, Michigan - preliminary results." Proc. of the 5th Annual National Conference on Beach Preservation Technology. St. Petersburg, FL.

Parson, L. E., and Smith, J. B. (1995). "Assessment of native beach characteristics for St. Joseph, Michigan, Southeastern Lake Michigan," Miscellaneous Paper CERC-95-2, U.S. Army Engineer Waterways Experiment Station, Vicksburg, MS.

Parson, L. E., Morang, A., and Nairn, R. B. (1996). "Geologic effects on behavior of beach fill and shoreline stability for southeast Lake Michigan," Technical Report CERC-96-10, U.S. Army Engineer Waterways Experiment Station, Vicksburg, MS.

Philpott, K. L. (1986). "Coastal engineering aspects of the Port Burwell shore erosion damage litigation." Proc. of Cohesive Shores, National Research Council, Ottawa, Canada. 309-38.

Shabica, C., and Pranschke, F. (1994). "Survey of littoral drift sand deposits along the Illinois and Indiana shores of Lake Michigan." Journal of Great Lakes Research 20(1), 61-72.

Southgate, H. N., and Nairn, R. B. (1993). "Deterministic profile modelling of nearshore processes; Part 1, waves and currents," Coastal Engineering 19, 27-56.

Stewart, C. J., and Pope, J. (1993). "Erosion Processes Task Group Report." Working Committee 2, Land Use and Management, International Joint Commission, Great Lakes-St. Lawrence Water Levels Reference Study Board.

U.S. Army Corps of Engineers. (1973). "Section 111 detailed project report on shore damage at St. Joseph Harbor, Michigan," Detroit, MI. 


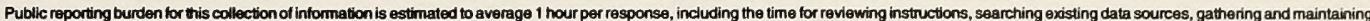

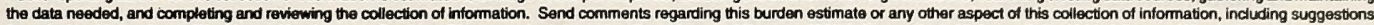

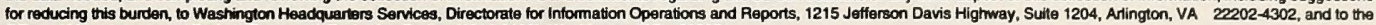
Office of Management and Budget, Paperwork Peduction Project (0704-0188), Washington, DC 20503.

\begin{tabular}{|c|c|c|}
\hline 1. AGENCY USE ONLY (Leave blank) & $\begin{array}{l}\text { 2. REPORT DATE } \\
\text { July } 1997\end{array}$ & $\begin{array}{l}\text { 3. REPORT TYPE AND DATES COVERED } \\
\text { Final report }\end{array}$ \\
\hline
\end{tabular}

4. TITLE AND SUBTTILE

Effectiveness of Beach Nourishment on Cohesive Shores, St. Joseph,

5. FUNDING NUMBERS

Lake Michigan

6. AUTHOR(S)

Robert B. Nairn, Peter Zuzek, Andrew Morang, Larry E. Parson

7. PERFORMING ORGANIZATION NAME(S) AND ADDRESS(ES)

W.F. Baird \& Associates, Coastal Engineers, Ltd.

221 Lakeshore Road East, Suite 30, Oakville, Ontario, Canada L6J 1 H7

U.S. Army Engineer Waterways Experiment Station

3909 Halls Ferry Road, Vicksburg, MS 39180-6199

9. SPONSORING/MONITORING AGENCY NAME(S) AND ADDRESS(ES)

U.S. Army Corps of Engineers

10. SPONSORINGMONTORING

AGENCY REPORT NUMBER

Washington, DC 20314-1000

11. SUPPLEMENTARY NOTES

Available from National Technical Information Service, 5285 Port Royal Road, Springfield, VA 22161.

12a. DISTRIBUTIONAVAILABILTYY STATEMENT

Approved for public release; distribution is unlimited.

8. PERFORMING ORGANIZATION REPORT NUMBER

Technical Report CHL-97-15

\section{ABSTRACT (Maximum 200 words)}

This report describes a study of the effectiveness of beach nourishment along the cohesive shore of St. Joseph Harbor on Lake Michigan. Objectives of the study were as follows:

a. To improve understanding of the sediment transport processes for both fine-grain and coarse-grain sand components at this site.

b. To improve understanding of the relationship between movement of the cohesionless sediment (both fine- and coarse-grain components) and the irreversible downcutting of the underlying glacial till (cohesive sediment) at this site.

c. To apply the improved understanding of the sediment transport and erosion processes in developing recommendations for beach nourishment at the St. Joseph site.

d. To formulate general principles for beach nourishment of cohesive shore sites that suffer from a sediment supply deficit due to the presence of an uplift littoral barrier.

Data in the form of repeated beach profiles, lake bed bathymetry, and shoreline recession rates are summarized. The results of a series of analyses performed to develop an understanding of the evolution of the shoreline and lake bed in the vicinity of St. Joseph, and the influence of the beach nourishment program on this evolution, are presented. A descriptive model of the historic coastal morphodynamics in the vicinity of St. Joseph is developed and presented, and this descriptive

(Continued)

14. SUBJECT TERMS

Beach nourishment

Coastal morphodynamics
Sediment transport

St. Joseph Harbor
15. NUMBER OF PAGES 102

16. PRICE CODE

17. OF REPORT UNCLASSIFIED

SECURITY CLASSIFICATION OF THIS PAGE

UNCLASSIFIED 
13. ABSTRACT (Concluded).

model is used to project the future evolution of coastal morphology. Recommendations for future nourishment efforts at St. Joseph are made on the basis of establishing realistic goals for the program. 

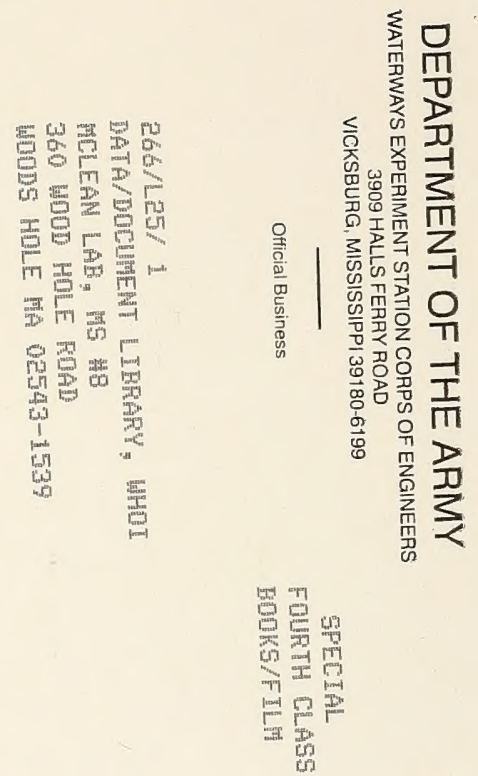